\author{
Mon og r a p h \\ urn:Isid:zoobank.org:pub:E9F1E40A-E78B-48C4-A077-124D01696B5E
}

\title{
A glimpse into a remarkable unknown diversity of oniscideans along the Caribbean coasts revealed on a tiny island
}

\author{
Carlos Mario LÓPEZ-OROZCO ${ }^{1, *}$, Yesenia M. CARPIO-DÍAZ ${ }^{2}$, Ricardo BORJA-ARRIETA ${ }^{3}$, \\ Gabriel R. NAVAS-S. ${ }^{4}$, Ivanklin Soares CAMPOS-FILHO ${ }^{5}$, Stefano TAITI ${ }^{6}$, \\ Mariana MATEOS $^{7}$, Alexandra OLAZARAN ${ }^{8}$, Isabel C. CABALLERO ${ }^{9}$, Karick JOTTY ${ }^{10}$, \\ Harold GÓMEZ-ESTRADA ${ }^{11}$ \& Luis A. HURTADO ${ }^{12}$ \\ ${ }^{1,2,3,4}$ Grupo de Investigación en Biología Descriptiva y Aplicada, Universidad de Cartagena, Programa \\ de Biología, Campus San Pablo, Cartagena de Indias, Colombia. \\ ${ }^{4}$ Grupo de Investigación Hidrobiología, Programa de Biología, Universidad de Cartagena, Campus
}

San Pablo, Cartagena de Indias, Colombia.

${ }^{5}$ Department of Biological Sciences, University of Cyprus, Lefkosia (Nicosia), Cyprus.

${ }^{6}$ Istituto di Ricerca sugli Ecosistemi Terrestri, Consiglio Nazionale delle Ricerche,

Sesto Fiorentino (Florence), Italy.

${ }^{6}$ Museo di Storia Naturale dell'Università, Sezione di Zoologia "La Specola", Florence, Italy.

7,8,9,12 Department of Ecology and Conservation Biology, Texas A\&M University,

College Station, Texas, USA.

${ }^{10,11}$ Grupo de Investigación en Química de Medicamentos, Facultad de Ciencias Farmacéuticas, Universidad de Cartagena, Campus Zaragocilla, Cartagena de Indias, Colombia.

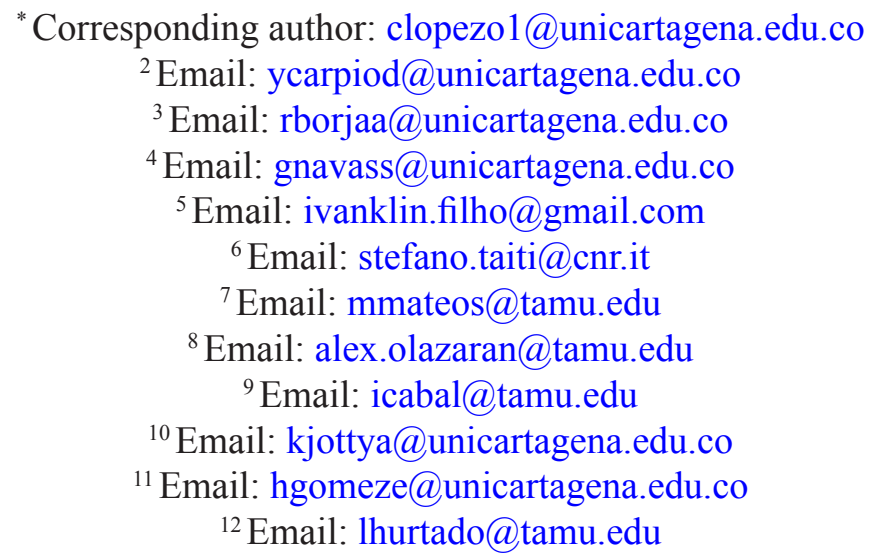

${ }^{1}$ urn:1sid:zoobank.org:author:5F6D82D6-FA27-43F0-8EBE-D0A72C6907D7

${ }^{2}$ urn:1sid:zoobank.org:author:1A9C855D-7795-4986-A27E-209AC10843BF

${ }^{3}$ urn:lsid:zoobank.org:author:263A3284-0AEF-4AB3-9C61-74F911206927

${ }^{4}$ urn:1sid:zoobank.org:author:388247A2-0357-475A-A500-9C5A484A3E4B

${ }^{5}$ urn:lsid:zoobank.org:author:C752F864-3C84-4AF4-9EDA-4D1AF464D615

${ }^{6}$ urn:1sid:zoobank.org:author:62E97059-6AE5-4984-9ABB-7FB6F7358BD6

${ }^{7}$ urn:lsid:zoobank.org:author:9131DC88-E777-4ED1-A3CD-D52161 A56968

${ }^{8}$ urn:Isid:zoobank.org:author:59E05AE4-D918-4A51-AB00-44361BB59B6D 


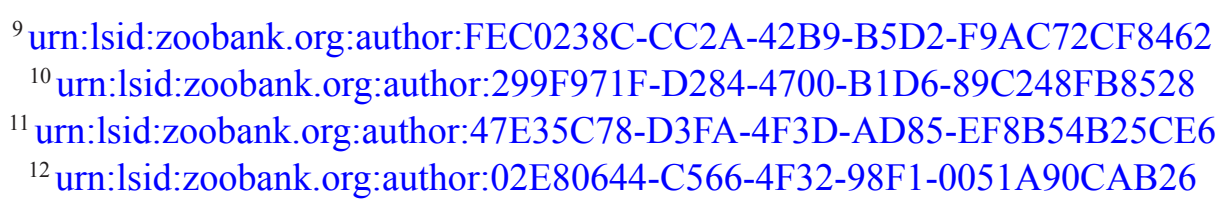

\begin{abstract}
In this study, we report the results of a taxonomic survey of terrestrial isopods from Isla Grande, a ca $2 \mathrm{~km}^{2}$ island located in the north of Cartagena de Indias, Colombia. We found a total of 17 species belonging to nine families and 10 genera. Eight of these species have been reported only from the Caribbean region, nine are recorded for the first time in Colombia, and three are new to science and described here: Tylos negroi López-Orozco, Carpio-Díaz \& Campos-Filho sp. nov., Stenoniscus nestori López-Orozco, Taiti \& Campos-Filho sp. nov. and Armadilloniscus luisi Carpio-Díaz, Taiti \& Campos-Filho sp. nov. Our revision also determined that the genus Microphiloscia is a junior synonym of Halophiloscia; and moreover, Halophiloscia trichoniscoides comb. nov. is redescribed. We also provide illustrations for Armadilloniscus caraibicus and Armadilloniscus ninae. Most (16) of the species were found in coastal habitats (i.e., beaches, coastal lagoons and mangroves), whereas the tropical dry forest harbored only two species. Molecular phylogenetic inferences supported the presence of three species of Tylos in Isla Grande (i.e., one new species and a new lineage within each of two known species). Our work on Tylos highlights the importance of combining taxonomic and molecular analyses to support taxonomic decisions and uncover cryptic diversity. Due to the multiple threats to Caribbean coastal habitats, taxonomic and molecular genetic research are urgently needed to understand biodiversity patterns of oniscideans in the Caribbean, which will inform strategies for their protection. Such studies will also contribute to our knowledge of their evolution, ecology, and potential uses, as well as the factors that have shaped the remarkable Caribbean biodiversity.
\end{abstract}

Keywords. Caribbean Islands, mangroves, Tropical Dry Forest, terrestrial isopods.

López-Orozco C.M., Carpio-Díaz Y.M., Borja-Arrieta R., Navas-S. G.R., Campos-Filho I.S., Taiti S., Mateos M., Olazaran A., Caballero I.C., Jotty K., Gómez-Estrada H. \& Hurtado L.A. 2022. A glimpse into a remarkable unknown diversity of oniscideans along the Caribbean coasts revealed on a tiny island. European Journal of Taxonomy 793: 1-50. https://doi.org/10.5852/ejt.2022.793.1643

\title{
Introduction
}

Terrestrial isopods (Oniscidea Latreille, 1802) constitute one of the most diverse groups within Isopoda Latreille, 1817, including more than 3800 species in 38 families and more than 500 genera (Schmalfuss 2003; Javidkar et al. 2015, 2017; Sfenthourakis \& Taiti 2015). They appear to form a monophyletic group, with the exception of the predominantly marine supralittoral genus Ligia Fabricius, 1798, which, according to recent molecular phylogenetic analyses, seems to be more closely related to marine isopods (Lins et al. 2017; Dimitriou et al. 2019). Pending a taxonomic revision, however, in this study we treat Ligia as being within the Oniscidea. Oniscideans are distributed in almost all terrestrial habitats, from the marine supralittoral to high mountain ranges, and from tropical forest to deserts, being absent in polar regions (Warburg 1993; Schmalfuss 2003; Sfenthourakis et al. 2020; WoRMS 2020a). A very large number of oniscideans remains to be discovered, but the taxonomic impediment is still a major cause of the delay in the recognition of this fauna (Ebach et al. 2011; Campos-Filho et al. 2014, 2020; Coleman 2015). Recent molecular studies have uncovered high levels of cryptic diversity within nominal species of marine coastal oniscideans that were considered broad-ranging, but that instead encompass many genetically highly differentiated lineages, each with relatively small ranges (Hurtado et al. 2010, 2013, 2014, 2018; Eberl et al. 2013; Santamaria et al. 2013, 2014). Their high potential for diversification stresses the importance of continuing taxonomic and systematic studies of oniscideans in coastal habitats, to better recognize their patterns of diversity, which, in turn, will serve as the foundation 
for understanding aspects of their ecology, evolution and potential uses (Hurtado et al. 2014; GarcíaHernández et al. 2015; Mattos et al. 2018). In addition, coastal habitats are under high pressure from sea level rise, pollution, and habitat destruction and modification (e.g., Guarderas et al. 2008; Lorde et al. 2013). Thus, it is urgent to identify the diversity of coastal oniscideans to better design conservation strategies, which can in turn benefit other species in this environment (Hurtado et al. 2010, 2013; Santamaria et al. 2013).

The Caribbean region is considered a natural laboratory for research on biodiversity evolution. A complex geological history, along with other factors, has contributed to a remarkable diversity of marine and terrestrial organisms, the highest in the Atlantic Basin (Myers et al. 2000; Roberts et al. 2002; Brummitt \& Lughadha 2003; Kerswell 2006; Ricklefs \& Bermingham 2008; Miloslavich et al. 2010). Although oniscideans have long been considered a group that can be highly informative on Caribbean biogeography (Rosen 1975), they have been poorly studied in this region. Two recent molecular phylogenetic studies showed a high level of diversification of coastal oniscideans in this region. Santamaria et al. (2014) identified a phylogenetic clade of supralittoral Ligia distributed in the Caribbean Sea, Bahamas, southern Florida, Bermuda, and the Pacific coast of Central America and Colombia, which represented the range of Ligia baudiniana Milne-Edwards, 1840. The authors recovered seven highly divergent lineages within this clade, probably corresponding to different species, five of which were observed in the Caribbean and two in the Pacific. Similarly, high levels of genetic differentiation have been reported for some Caribbean populations of another supralittoral oniscidean, Tylos sp., even over relatively short geographic distances (Hurtado et al. 2014). However, sampling of Tylos Audouin, 1826 was very limited and more efforts are needed throughout the Caribbean Sea to better understand the diversity of this taxon in the region. These two studies suggest that a high diversity of coastal oniscideans in the Caribbean is yet to be discovered, underscoring the importance of taxonomic and molecular systematics studies for these organisms in the region.

Despite an extensive coastline of about $1600 \mathrm{~km}$ of the Caribbean Sea in Colombia, studies of the diversity of oniscideans in coastal habitats have been very limited. Van Name (1936) recorded Porcellionides pruinosus (Brandt, 1833) from San Andrés Island, a Colombian island located about $190 \mathrm{~km}$ off the coast of Nicaragua. López-Orozco et al. (2014) recorded L. baudiniana from Cartagena de Indias, northern Bolívar. Carpio-Díaz et al. (2016) recorded Tylos niveus Budde-Lund, 1885 and P. pruinosus from Barú Island, northern Bolívar. López-Orozco et al. (2017) described Pulmoniscus turbanaensis López-Orozco, Carpio-Díaz \& Campos-Filho, 2017 from northern Bolívar, including specimens from Tierra Bomba Island. In addition, one of the five Ligia clades identified by Santamaria et al. (2014) in the Caribbean was observed on the coast of the Magdalena Department of Colombia.

Herein, we conducted a taxonomic survey of the oniscideans present at littoral, mangrove, and inland habitats of Isla Grande, a tiny island off the Caribbean coast of Colombia. Detailed external morphology was examined for all samples. In addition, we conducted molecular phylogenetic analyses of specimens of Tylos. Based on these examinations, three new species of oniscideans are described, and one previous junior synonym is redescribed. Full illustrations of the new and several species are provided as well as a taxonomic key for the identification of all species. Our study highlights the immense potential of combined taxonomic and molecular systematics studies to uncover the diversity of oniscideans in coastal habitats of the Caribbean Basin, a region that needs urgent attention due to the multiple threats to its conservation.

\section{Material and methods}

\section{Study area}

Isla Grande is located in the archipelago of Nuestra Señora del Rosario, in the Colombian Caribbean, separated by $4.6 \mathrm{~km}$ from the continent (the closest point is Barú), and has an area of about $2 \mathrm{~km}^{2}$ 


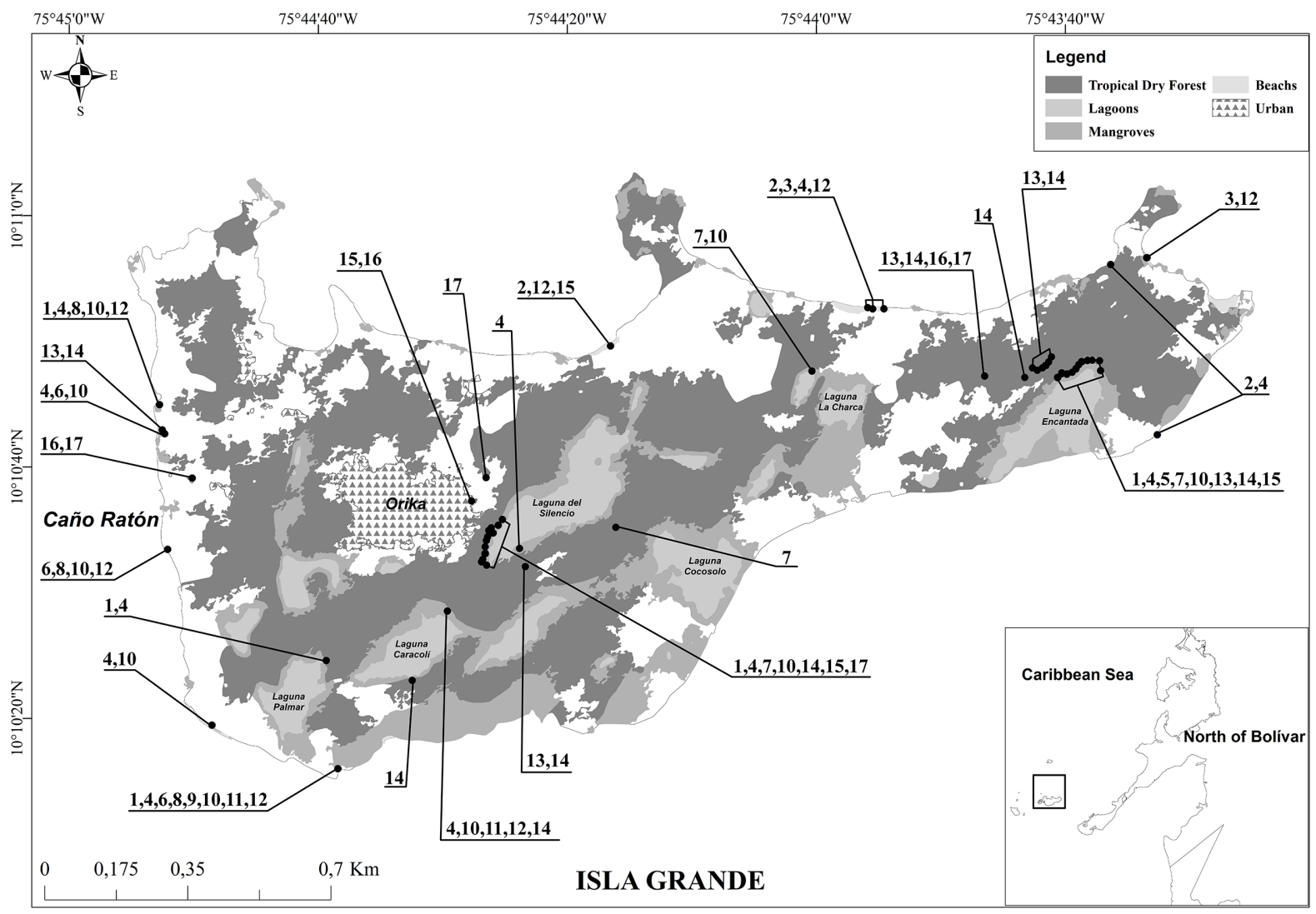

Fig. 1. Map of the study areas and distribution of species of terrestrial isopods from Isla Grande. 1. Ligia baudiniana Milne Edwards, 1840. 2. Tylos negroi López-Orozco, Carpio-Díaz \& Campos-Filho sp. nov. 3. Tylos marcuzzii Giordani Soika, 1954. 4. Tylos niveus Budde-Lund, 1885. 5. Stenoniscus nestori López-Orozco, Taiti \& Campos-Filho sp. nov. 6. Armadilloniscus caraibicus Paoletti \& Stinner, 1989. 7. Armadilloniscus luisi Carpio-Díaz, Taiti \& Campos-Filho sp. nov. 8. Armadilloniscus ninae Schultz, 1984. 9. Halophiloscia trichoniscoides (Vandel, 1973) comb. nov. 10. Littorophiloscia amphindica Taiti \& Ferrara, 1986. 11. Littorophiloscia denticulata (Ferrara \& Taiti, 1982). 12. Littorophiloscia tropicalis Taiti \& Ferrara, 1986. 13. Trichorhina heterophthalma Lemos de Castro, 1964. 14. Trichorhina bermudezae Carpio-Díaz, López-Orozco \& Campos-Filho, 2018. 15. Porcellionides pruinosus (Brandt, 1833). 16. Agnara madagascariensis (Budde-Lund, 1885). 17. Ctenorillo tuberosus (Budde-Lund, 1904).

(Fig. 1). The climate classification is semi-arid tropical domain, with an average annual temperature of $24.7^{\circ} \mathrm{C}\left(\min 21^{\circ} \mathrm{C}, \max 33^{\circ} \mathrm{C}\right)$, average annual precipitation of $916 \mathrm{~mm}$ and humidity ranging between 80\% and 85\% (Pineda et al. 2006; Niño et al. 2010).

This study was conducted in mangrove, littoral zones, Tropical Dry Forest (TDF), and inhabited areas of the island. The mangrove ecosystem is located on the edge of the inland lagoons and swamps, with a forest strip no wider than $80 \mathrm{~m}$, with vegetation composed of Avicennia germinans (L.)L., Laguncularia racemosa L., Conocarpus erectus L. and Rhizophora mangle (L.)C.DC, the last one being the dominant species (Rojas et al. 2012; Romero \& Niño 2014). The littoral zone includes rocky and sandy beaches. These ecosystems in the area comprise a wide diversity of invertebrates (Núñez et al. 1999). The beaches on Isla Grande are narrow and characterized by discontinuous white sand portions fragmented by rocky coastline (Romero \& Niño 2014). The TDF is the main vegetative cover of the island, represented 
by Gliricidia sepium (Jacq.)Kunth ex Walp., Guazuma ulmifolia Lam., Spondias mombin L., Bursera simaruba (L.)Sarg., Astronium graveolens Jacq., Morinda panamensis Seem. and Cnidoscolus urens (L.)Arthur (Rojas et al. 2012).

\section{Taxonomy}

Two sampling methodologies were used. Direct Intuitive Searches (Taiti \& Wynne 2015), implemented at all sites, consisted of hand-collection of specimens during searches in the sand and decomposing organic matter, roots and bark of trees, fallen logs and under rocks. The estimated time of the searches was about 20 minutes per observer (three observers) at each sampling site. In the TDF, we also used a Winkler sack (mesh size: $1 \mathrm{~cm}$ ) to screen leaf litter; extraction of specimens was performed immediately by spreading the material on a white cloth. The specimens were preserved in $75 \%$ ethanol. The identifications were based on morphological characters with the use of micropreparations. The illustrations were made from photographs taken with Axio Lab A1 microscope and SteREO Discovery.V12 ZEISS stereo microscope with an adapted Axiocam ERc 5s camera and the aid of a camera lucida mounted on Wild M5 and M20 microscopes. The final illustrations were prepared using the software GIMP (ver. 2.8) with the method proposed by Montesanto $(2015,2016)$. For the already described species, material examined and distributions are presented. The synonymy lists include original descriptions and publications mentioning species occurring in Colombia. Additional references containing relevant taxonomic and distribution data are also included when necessary. For each new species, the type material, etymology, description, remarks, and distribution are given. The material is deposited in the research laboratories of the Biology program at Cartagena University, Cartagena, Colombia (CUDC-CRU) and the Collection of Isopod Crustaceans of the Instituto de Ciencias Naturales, National University of Colombia, Bogotá, Colombia (ICN-CR-is). Specimens from Cuba are deposited in the Museo di Storia Naturale, Sezione di Zoologia "La Specola", Florence, Italy (MZUF).

\section{Molecular phylogenetic analyses of specimens of Tylos Audouin, 1826}

Genomic DNA was isolated from 1 leg for seven specimens of Tylos with the DNEasy kit, following the manufacturer's protocol (Qiagen Inc., Valencia, CA). These specimens represented the three different species identified by taxonomic analyses and different localities where they were sampled (see Results): Tylos marcuzzii Giordani Soika, 1954 from La Punta; Tylos niveus from Laguna Caracolí and Caño Ratón; and Tylos negroi López-Orozco, Carpio-Díaz \& Campos-Filho sp. nov. from Playa Libre, El Silencio and La Punta-El Terminal. We attempted to PCR-amplify fragments of the mitochondrial genes 16S rDNA (using primers 16Sar and 16Sbr) and 12S rDNA (using primers Crust-12f and Crust12r; primers and PCR conditions in Hurtado et al. 2013). PCR-amplified products were cleaned with Exonuclease and Shrimp Alkaline Phosphatase, and subsequently cycle sequenced using the Sanger method. We used the software Sequencher ver. 4.8 (Gene Codes, Ann Arbor, MI) for sequence editing and primer removal.

The sequences obtained were manually aligned with sequences of the 16S rDNA and 12S rDNA mitochondrial genes for 17 of the 21 nominal species of Tylos, reported in Hurtado et al. $(2013,2014)$. In addition, we included a $16 \mathrm{~S}$ rDNA sequence from a specimen identified as $T$. niveus collected at

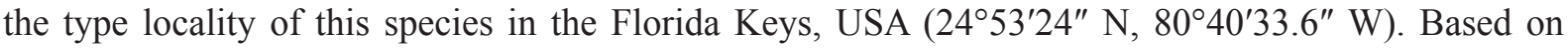
preliminary phylogenetic analyses, we identified the closest relatives to the new specimens to generate a smaller dataset (i.e., clade $\mathrm{N}$ in Hurtado et al. 2014) that excluded highly divergent taxa, which are more likely to produce homoplasies and complicate homology assessments. Alignments of the 12S rDNA, the 16S rDNA, and both genes concatenated, indicating included and excluded positions in subsequent analyses, are available as Supplementary file 1, Supplementary file 2 and Supplementary file 3. We used IQTree ver. 1.6.12 (Lam-Tung et al. 2015) to implement ModelFinder (Kalyaanamoorthy et al. 2017) and perform maximum likelihood (ML) analyses with standard bootstrap (100 replicates) and the Shimodaira-Hasegawa approximate Likelihood Ratio Test (SH-aLRT; 1000 replicates). We used 
Table 1. List of terrestrial isopods from Isla Grande. Abbreviations: $\mathrm{A}=$ Americas; $\mathrm{C}=$ Caribbean; $\mathrm{CO}=$ Cosmopolitan; $\mathrm{CSA}=$ Central and South America; $\mathrm{P}=$ Pantropical; TDF $=$ Tropical Dry Forest. * indicates first record for Colombia.

\begin{tabular}{|c|c|c|c|c|c|}
\hline \multirow{2}{*}{ Family/Species } & \multicolumn{4}{|c|}{ Habitat sampled } & \multirow{2}{*}{ Distribution } \\
\hline & Littoral & Mangrove & TDF & Urban & \\
\hline
\end{tabular}

\section{Ligiidae}

Ligia baudiniana

Tylidae

Tylos niveus

Tylos negroi sp. nov.

Tylos marcuzzii *

\section{Stenoniscidae}

Stenoniscus nestori sp. nov.

\section{Detonidae}

Armadilloniscus caraibicus *

Armadilloniscus luisi sp. nov.

Armadilloniscus ninae *

\section{Halophilosciidae}

Halophiloscia trichoniscoides comb. nov. * Littorophiloscia amphindica *

Littorophiloscia denticulata*

Littorophiloscia tropicalis *

\section{Platyarthridae}

Trichorhina bermudezae

Trichorhina heterophthalma

\section{Porcellionidae}

Porcellionides pruinosus

Agnaridae

Agnara madagascariensis *

Armadillidae

Ctenorillo tuberosus *

$\underline{\text { Total }} 11$

\begin{tabular}{|c|c|c|c|c|}
\hline$X$ & $X$ & - & - & A \\
\hline$X$ & $X$ & - & - & A \\
\hline$X$ & - & - & - & $\mathrm{C}$ \\
\hline$X$ & - & - & - & $\mathrm{C}$ \\
\hline- & $X$ & - & - & $\mathrm{C}$ \\
\hline$X$ & - & - & - & $\mathrm{C}$ \\
\hline- & $X$ & - & - & $\mathrm{C}$ \\
\hline$X$ & - & - & - & $\mathrm{C}$ \\
\hline$X$ & - & - & - & $\mathrm{C}$ \\
\hline$X$ & $X$ & - & - & $\mathrm{P}$ \\
\hline$X$ & $X$ & - & - & $\mathrm{P}$ \\
\hline$X$ & $X$ & - & - & $\mathrm{P}$ \\
\hline- & $X$ & $X$ & $X$ & $\mathrm{C}$ \\
\hline- & $X$ & $X$ & $X$ & $\mathrm{P}$ \\
\hline$X$ & $X$ & - & $X$ & $\mathrm{CO}$ \\
\hline- & - & - & $X$ & $\mathrm{P}$ \\
\hline- & $\mathrm{X}$ & - & $\mathrm{X}$ & CSA \\
\hline 11 & 11 & 2 & 5 & \\
\hline
\end{tabular}

MrBayes ver. 3.2.7a x86_64 (Altekar et al. 2004; Ronquist et al. 2012) as implemented in the CIPRES web portal (phylo.org) to perform Bayesian analyses (parameters in Dataset S1-3). We used PAUP* ver. 4.0a (build 168) (Swofford 2002) to compute pairwise uncorrected p-distances among taxa, for which all positions in the alignment were used, with missing or ambiguous positions ignored for each pairwise comparison.

\section{Results}

A total of 17 species of oniscideans belonging to nine families and 10 genera were identified from Isla Grande. Of these, 16 were collected in coastal habitats (littoral and mangroves), two in Tropical Dry Forest, and five in urban habitats (Table 1). 


\section{Systematic account}

Order Isopoda Latreille, 1817

Suborder Oniscidea Latreille, 1802

Family Ligiidae Leach, 1814

Genus Ligia Fabricius, 1798

Ligia baudiniana Milne-Edwards, 1840

Fig. 1

Ligia baudiniana Milne-Edwards, 1840: 155.

Ligia (Hirtiligia) baudiniana - Van Name 1936: 58, figs 5a, 14.

Ligia baudiniana - Ríos \& Ramos 1990: 93, fig. 7. - Schmalfuss 2003: 124. — Lazarus-Agudelo \& Cantera-Kintz 2007: 226. — López-Orozco et al. 2014: 196, figs 1-3.

\section{Additional references}

Jackson (1922); Schultz (1984); Kensley \& Schotte (1989); Leistikow (1997); Leistikow \& Wägele (1999); Espinosa-Pérez \& Hendrickx (2001); Santamaria et al. (2014).

\section{Material examined}

COLOMBIA - Bolívar, Cartagena de Indias, Islas del Rosario, Isla Grande -3 ô $\hat{o}, 1$ q; El Silencio, Laguna del Silencio; 10¹0'34.8" N, 7544'26.6" W; 24 Aug. 2017; C.M. López-Orozco, R. Borja-Arrieta and Y.M. Carpio-Díaz leg.; CUDC-CRU $141 \bullet 3 \widehat{\partial} \widehat{\jmath}, 2$ 우; same collection data as for preceding; $10^{\circ} 10^{\prime} 35^{\prime \prime} \mathrm{N}, 75^{\circ} 44^{\prime} 26.4^{\prime \prime} \mathrm{W}$; CUDC-CRU $142 \cdot 1$ juv.; same collection data as for preceding; $10^{\circ} 10^{\prime} 35.4^{\prime \prime} \mathrm{N}, 75^{\circ} 44^{\prime} 26.2^{\prime \prime} \mathrm{W}$; CUDC-CRU $143 \cdot 1$ ô, 1 \%; same collection data as for preceding; $10^{\circ} 10^{\prime} 34.3^{\prime \prime} \mathrm{N}, 75^{\circ} 44^{\prime} 26.7^{\prime \prime} \mathrm{W}$; CUDC-CRU $144 \cdot 1$; ; same locality and collectors as for preceding; $10^{\circ} 10^{\prime} 32.9^{\prime \prime} \mathrm{N}, 75^{\circ} 44^{\prime} 27.3^{\prime \prime} \mathrm{W}$; 25 Aug. 2017; CUDC-CRU 145 • 1 क ; same collection data as for preceding; $10^{\circ} 10^{\prime} 32.3^{\prime \prime} \mathrm{N}, 75^{\circ} 44^{\prime} 27.2^{\prime \prime} \mathrm{W}$; CUDC-CRU 146 • 1 ' ; same collection data as for preceding; $10^{\circ} 10^{\prime} 32.5^{\prime \prime} \mathrm{N}, 75^{\circ} 44^{\prime 2} 27.1^{\prime \prime} \mathrm{W}$; CUDC-CRU 147 • 1 q; Caño Ratón, Laguna Palmar; $10^{\circ} 10^{\prime} 24.5^{\prime \prime} \mathrm{N}$,

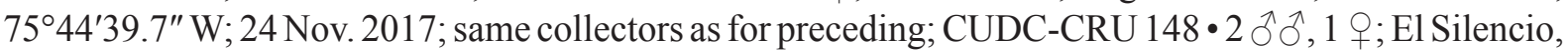
Laguna del Silencio; $10^{\circ} 10^{\prime} 35.4^{\prime \prime} \mathrm{N}, 75^{\circ} 44^{\prime} 26^{\prime \prime} \mathrm{W} ; 24$ Nov. 2017; same collectors as for preceding; CUDC-CRU 149 • 1 \%; same locality and collectors as for preceding; $10^{\circ} 10^{\prime} 48^{\prime \prime} \mathrm{N}, 75^{\circ} 43^{\prime} 39.3^{\prime \prime} \mathrm{W}$; 25 Aug. 2017; CUDC-CRU 150 • $1 \mathrm{O}^{\top}$; same collection data as for preceding; $10^{\circ} 10^{\prime} 34^{\prime \prime} \mathrm{N}, 75^{\circ} 44^{\prime} 26.8^{\prime \prime} \mathrm{W}$; CUDC-CRU 151 - 1 juv.; same collection data as for preceding; $10^{\circ} 10^{\prime} 47.74^{\prime \prime} \mathrm{N}, 75^{\circ} 43^{\prime} 39.93^{\prime \prime} \mathrm{W}$; CUDC-CRU 152 • 1 Oे, 1 q; same collection data as for preceding; $10^{\circ} 10^{\prime} 35^{\prime \prime} \mathrm{N}, 75^{\circ} 44^{\prime} 26.9^{\prime \prime} \mathrm{W}$; ICN-

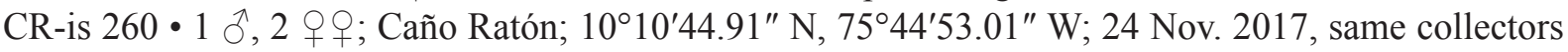

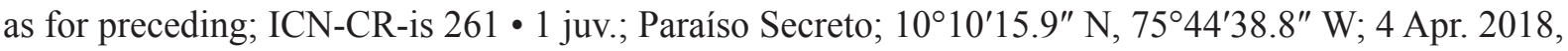
C.M. López-Orozco, R. Borja-Arrieta and K. Meza leg.; CUDC-CRU 222.

\section{Previous records}

Valle del Cauca: Bahía Málaga (Pacific); Bolívar: Cartagena de Indias (Caribbean); Magdalena: Santa Marta (Ríos \& Ramos 1990; Lazarus-Agudelo \& Cantera-Kintz 2007; López-Orozco et al. 2014; Santamaria et al. 2014).

\section{Distribution}

This species was originally described from Veracruz, Mexico (but see Discussion). Molecular phylogenetic analyses, however, revealed that what has been denominated as this species corresponds to a clade composed of highly divergent lineages (probably a complex of cryptic species), distributed in southern Florida, across the Caribbean Sea, Bahamas, Bermuda, and probably in northern Brazil, and 
the Pacific coast from Costa Rica, Panamá, Colombia, probably to Ecuador (Santamaria et al. 2014). Although this species has been reported in the Gulf of California and California, extensive sampling for phylogeographic studies conducted by some of us suggest that these previous records are likely misidentifications (Hurtado et al. 2010; Eberl et al. 2013; Hurtado et al. 2018).

Family Tylidae Dana, 1852

Genus Tylos Audouin, 1826

Tylos niveus Budde-Lund, 1885

Fig. 1

Tylos niveus Budde-Lund, 1885: 278.

Tylos niveus - Carpio-Díaz et al. 2016: 435, fig. 3.

\section{Additional references}

Boone (1934); Van Name (1936); Schultz (1970); Kensley \& Schotte (1989); Silva \& Alves (2000); Hurtado et al. (2014); Taiti et al. (2018).

\section{Material examined}

COLOMBIA - Bolívar, Cartagena de Indias, Islas del Rosario, Isla Grande • $3 \widehat{\partial} \partial^{\lambda}, 1$ q; La Punta, Laguna Encantada; $10^{\circ} 10^{\prime} 48.1^{\prime \prime} \mathrm{N}, 7^{\circ} 43^{\prime} 37.5^{\prime \prime} \mathrm{W} ; 24$ Aug. 2017; Y.M. Carpio-Díaz, C.M. López-

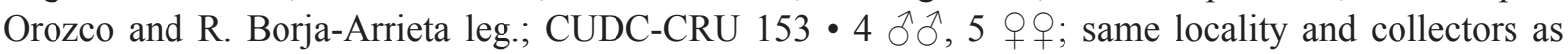

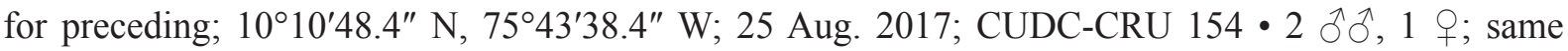

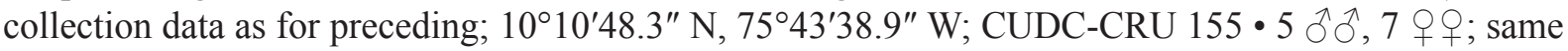

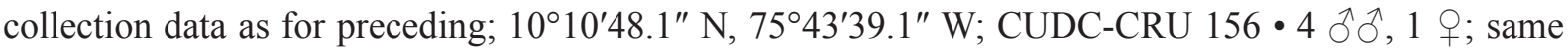

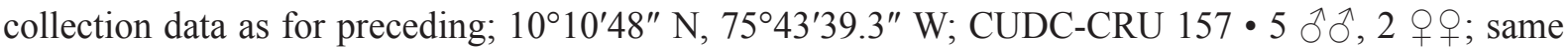
collection data as for preceding; $10^{\circ} 10^{\prime} 47.72^{\prime \prime} \mathrm{N}, 75^{\circ} 43^{\prime} 40.09^{\prime \prime} \mathrm{W}$; CUDC-CRU $158 \cdot 2 \mathrm{o}^{\Uparrow} \mathrm{o}^{\prime}, 1$ \% same collection data as for preceding; $10^{\circ} 10^{\prime} 47.76^{\prime \prime} \mathrm{N}, 75^{\circ} 43^{\prime} 40.27^{\prime \prime} \mathrm{W}$; CUDC-CRU $159 \cdot 5$ ⿵े $^{\lambda}$, 2 우우; same collection data as for preceding; $10^{\circ} 10^{\prime} 47.7^{\prime \prime} \mathrm{N}, 75^{\circ} 43^{\prime} 39.93^{\prime \prime} \mathrm{W}$; CUDC-CRU 160 •

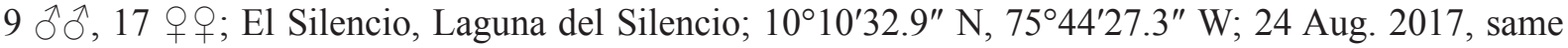

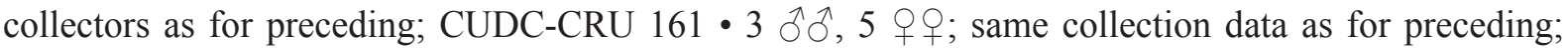

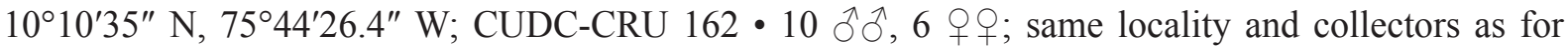

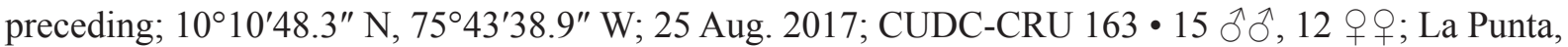
El Terminal; $10^{\circ} 10^{\prime} 55.75^{\prime \prime} \mathrm{N}, 7^{\circ} 43^{\prime} 36.57^{\prime \prime} \mathrm{W} ; 6$ Oct. 2017; C.M. López-Orozco leg.; ICN-CR-is

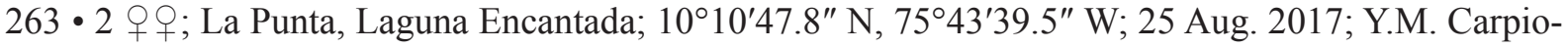

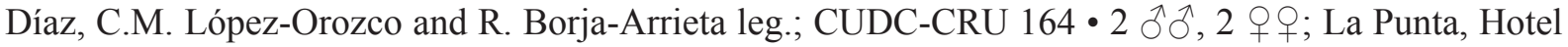
Cocoliso; $10^{\circ} 10^{\prime} 42.19^{\prime \prime} \mathrm{N}, 75^{\circ} 43^{\prime} 32.88^{\prime \prime} \mathrm{W}$; 6 Oct. 2017; same collectors as for preceding; CUDCCRU 165 • 4 우; Hotel La Pola; 10¹0'19.4" N, 7544'48.9" W; 24 Nov. 2017; same collectors as for

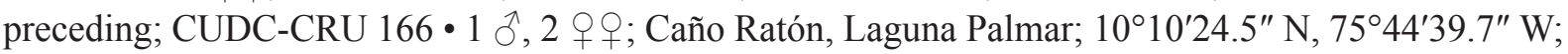
same date and collectors as for preceding; CUDC-CRU $167 \bullet 4 \jmath^{\lambda} \partial^{\lambda}, 5$ 우 ; Playa Libre; $10^{\circ} 10^{\prime} 52.3^{\prime \prime} \mathrm{N}$, 7543'55.7" W; same date as for preceding; C.M. López-Orozco leg.; CUDC-CRU $168 \cdot 3 \overbrace{}^{\Uparrow}, 2$ 우; El Silencio, Laguna del Silencio; 10¹0'34.3" N, 7544'26.7" W; 24 Aug. 2017; C.M. López-Orozco, Y.M. Carpio-Díaz and R. Borja-Arrieta leg.; CUDC-CRU 169 • 1 \%; El Silencio, Laguna del Silencio;

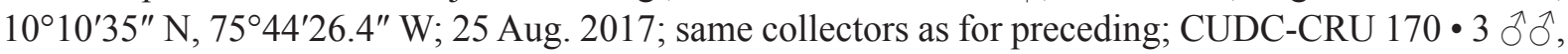
6 우, 1 juv.; Paraíso Secreto; 10¹0'15.9" N, 7544'38.8" W; 24 Nov. 2017; C.M. López-Orozco leg.;

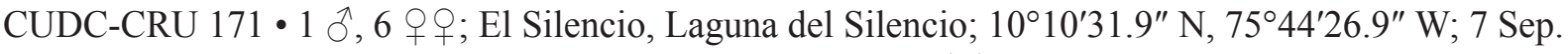

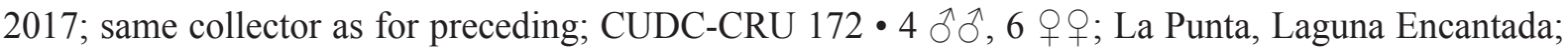
$10^{\circ} 10^{\prime} 48.1^{\prime \prime}$ N, 7543'37.5" W; 7 Sep. 2017; C.M. López-Orozco, Y.M. Carpio-Díaz and R. Borja- 


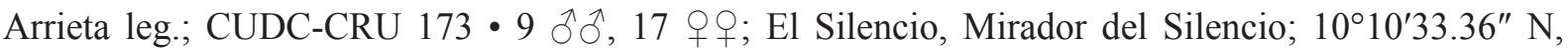

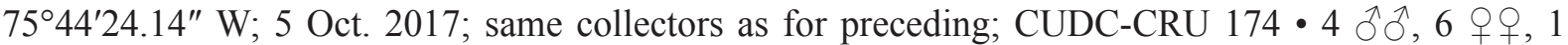
juv.; Caño Ratón; 10¹0'44.91" N, 7544'53.01" W; 24 Nov. 2017; C.M. López-Orozco leg.; CUDCCRU 175 • 29 đ̊ ô, 38 우 o ; Paraíso Secreto; $10^{\circ} 10^{\prime} 15.9^{\prime \prime}$ N, 7544'38.8" W; 6 Sep. 2017; same collector

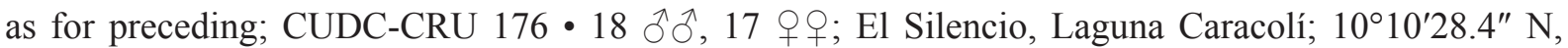

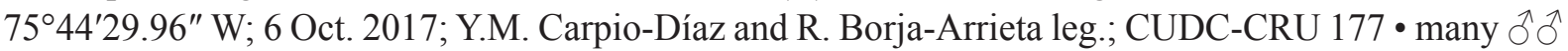
and + ; ; Caño Ratón; $10^{\circ} 10^{\prime} 42.6^{\prime \prime}$ N, 7544'52.6" W; 24 Nov. 2017; C.M. López-Orozco leg.; CUDC-

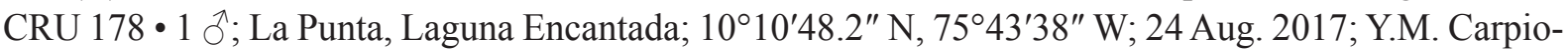
Díaz, C.M. López-Orozco and R. Borja-Arrieta leg.; CUDC-CRU 179 • 5 ふぇ, 8 우우 El Silencio, Laguna del Silencio; $10^{\circ} 10^{\prime} 35.4^{\prime \prime} \mathrm{N}, 75^{\circ} 44^{\prime} 26^{\prime \prime} \mathrm{W}$; same date and collectors as for preceding; CUDC-

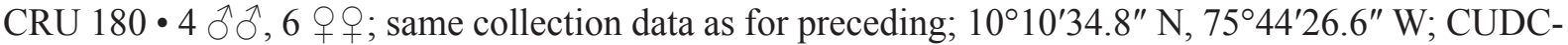

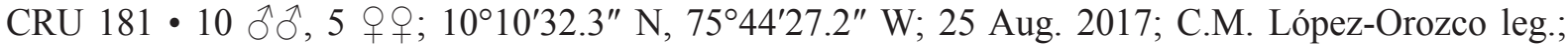

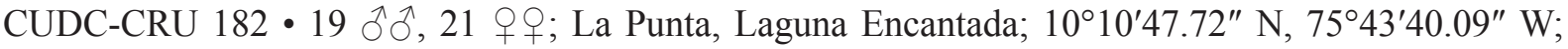
25 Aug. 2017; Y.M. Carpio-Díaz, C.M. López-Orozco and R. Borja-Arrieta leg.; CUDC-CRU 183 •

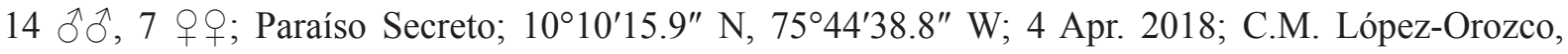

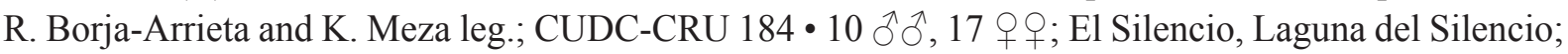
$10^{\circ} 10^{\prime} 35.4^{\prime \prime}$ N, 7544'26.2" W; 24 Aug. 2017; Y.M. Carpio-Díaz, C.M. López-Orozco and R. BorjaArrieta leg.; ICN-CR-is 264.

\section{Previous records}

Bolívar: Barú, Cartagena de Indias (Caribbean) (Carpio-Díaz et al. 2016).

\section{Distribution}

Widely distributed in Atlantic coastal areas of Mexico (Kensley \& Schotte 1989); Florida, Cuba (Van Name 1936); Bahamas, Tobago, Bonaire (Schultz 1974); Dominica, Curacao, Virgin Islands, Belize, Venezuela (Kensley \& Schotte 1989); Puerto Rico (Hurtado et al. 2014); Colombia (Carpio-Díaz et al. 2016); and Brazil (Silva \& Alves 2000). It is also present on the Pacific coast of Costa Rica (Taiti et al. 2018). First record of the species for continental islands of the Colombian Caribbean.

\section{Tylos marcuzzii Giordani Soika, 1954}

Figs 1, 2A

Tylos marcuzzii Giordani Soika, 1954: 79, fig. 10/1.

\section{Additional references}

Schultz (1974); Kensley \& Schotte (1989).

\section{Material examined}

COLOMBIA - Bolívar, Cartagena de Indias, Islas del Rosario, Isla Grande • 1 ; ; Playa Libre; $10^{\circ} 10^{\prime} 52.4^{\prime \prime}$ N, 7543'56.1" W; 7 Sep. 2017; C.M. López-Orozco, R. Borja-Arrieta and Y.M. Carpio-

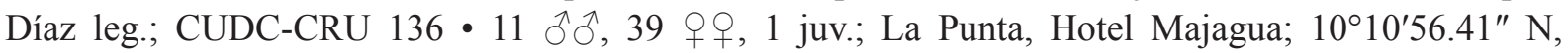
7543'33.51" W; 6 Oct. 2017; same collectors as for preceding; CUDC-CRU 137.

\section{Distribution}

Florida, Bahamas, Leeward Islands, Belize, Venezuela and Cuba (Schultz 1974; Kensley \& Schotte 1989; Schmalfuss \& Vergara 2000; Schmidt 2001; Schmalfuss 2003; Hurtado et al. 2014). First record for Colombia. 


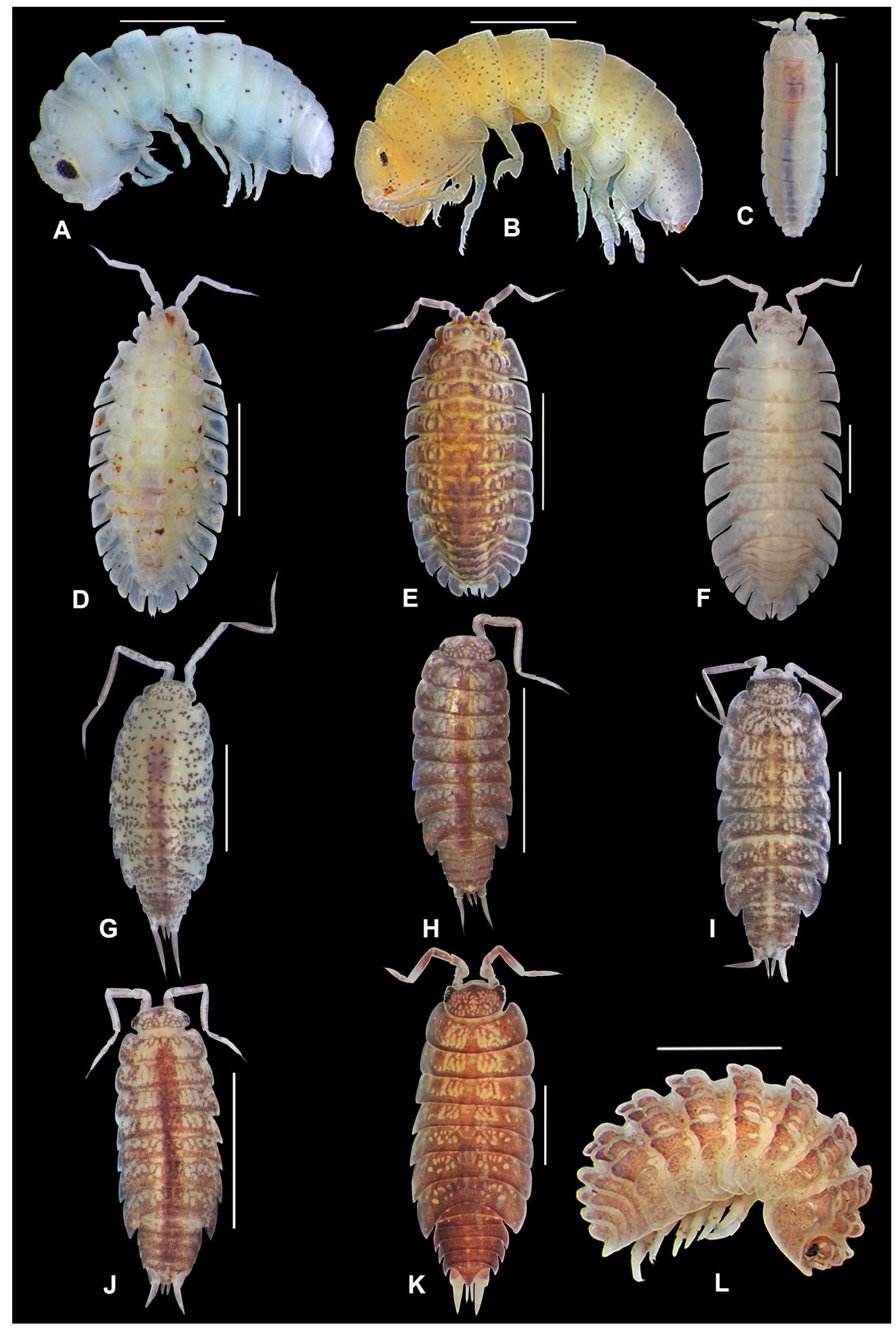

Fig. 2. A. Tylos marcuzzii Giordani Soika, 1954. B. Tylos negroi López-Orozco, Carpio-Díaz \& CamposFilho sp. nov. C. Stenoniscus nestori López-Orozco, Taiti \& Campos-Filho sp. nov. D. Armadilloniscus caraibicus Paoletti \& Stinner, 1989. E. Armadilloniscus luisi Carpio-Díaz, Taiti \& Campos-Filho sp. nov. F. Armadilloniscus ninae Schultz, 1984. G. Halophiloscia trichoniscoides (Vandel, 1973) comb. nov. H. Littorophiloscia amphindica Taiti \& Ferrara, 1986. I. Littorophiloscia denticulata (Ferrara \& Taiti, 1982). J. Littorophiloscia tropicalis Taiti \& Ferrara, 1986. K. Agnara madagascariensis (Budde-Lund, 1885). L. Ctenorillo tuberosus (Budde-Lund, 1904). Scale bars: $1 \mathrm{~mm}$. 
Tylos negroi López-Orozco, Carpio-Díaz \& Campos-Filho sp. nov. urn:lsid:zoobank.org:act:DFCDBD2C-AEBD-4754-951A-1D927E81E6DC

Figs 1, 2B, 3-5

\section{Etymology}

The new species is named after Mr Hernando Gómez Molina, also known as Mr Negro, for his efforts to conserve the biodiversity of the Rosario Islands.

\section{Material examined}

Holotype

COLOMBIA - Bolívar, Cartagena de Indias, Islas del Rosario, Isla Grande - đ̧; Playa Libre; $10^{\circ} 10^{\prime} 52.3^{\prime \prime}$ N, $75^{\circ} 43^{\prime} 54.8^{\prime \prime}$ W; 5 Oct. 2017; C.M. López-Orozco, R. Borja-Arrieta and Y.M. CarpioDíaz leg.; CUDC-CRU 127.

\section{Paratypes}

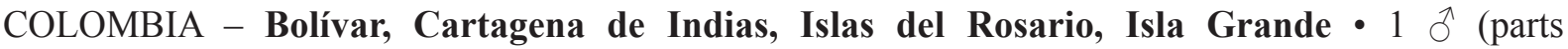
in micropreparations); same collection data as for holotype; CUDC-CRU $128 \cdot 2$ 우 (parts in micropreparations); same collection data as for holotype; CUDC-CRU $129 \cdot$ many $\hat{\jmath} \delta$ and $q 0+$; same

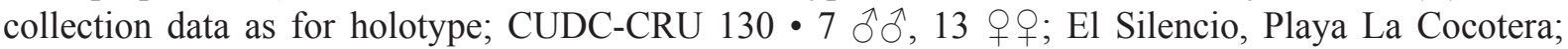

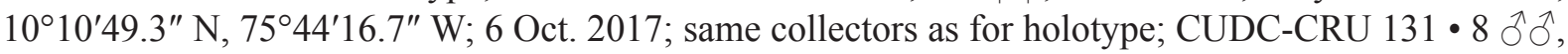
10 우울 La Punta, El Terminal; $10^{\circ} 10^{\prime} 55.75^{\prime \prime} \mathrm{N}, 75^{\circ} 43^{\prime} 36.57^{\prime \prime} \mathrm{W}$; same collectors as for holotype; CUDC-CRU 132 • 5 o 9 ; Playa Libre; $10^{\circ} 10^{\prime} 52.3^{\prime \prime}$ N, 7543'55.7" W; 7 Sep. 2017; same collectors as

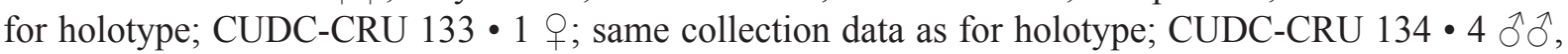
3 + $\odot$; same collection data as for holotype; 5 Oct. 2017; ICN-CR-is 262 • 1 § ; La Punta, Hotel Cocoliso; $10^{\circ} 10^{\prime} 42.19^{\prime \prime} \mathrm{N}, 75^{\circ} 43^{\prime} 32.88^{\prime \prime} \mathrm{W}$; 6 Oct. 2017; same collectors as for holotype; CUDC-CRU 135.

\section{Description}

MeAsurements. Maximum body length: male $10 \mathrm{~mm}$; female $8.1 \mathrm{~mm}$.

Body. Colour yellowish with many irregular dark spots (Fig. 2B). Body outline as in Fig. 3A. Endoantennal conglobation. Dorsum covered with lanceolate scale-setae (Fig. 3B).

Cephalon. Frontal lamina triangular (Fig. 3C-D); eyes consisting of 26-27 ommatidia.

Pereon. Pereonite 1 epimera grooved on lateral margins, schisma with inner lobe triangular, slightly surpassing outer lobe (Fig. 3E); pereonite 2 with ventral lobe triangular, shorter than outer lobe (Fig. 3E); epimera of pereonites 2-4 subtriangular, 5-7 subquadrangular (Fig. 3A).

Pleon. Epimera of pleonites 3-5 with rounded distal margin (Fig. 3F). Ventral phylacomera present on pleonites 3-5; phylacomera 5 oar-shaped, with wide distal part, medial margin oblique and slightly sinuous (Fig. 3G). Telson rectangular, posterior margin slightly folded upwards (Fig. 3F).

Antennula. Composed of one article, flattened and triangular, several aesthetascs inserted on slightly rounded lobe (Fig. 3H).

AnTENNA. Short and thickset, flagellum of three articles, apical article as long as first and second articles (Fig. 4A).

MouTH. Mandibles with strong molar process, left mandible (Fig 4B) with two penicils on molar process, two on hairy lobe and five free penicils; right mandible (Fig. 4C) with two penicils on molar process, one on hairy lobe and five free penicils. Maxillula (Fig. 4D) inner endite with three long penicils densely 
covered with thin setae, apical penicil longest; outer endite composed of $5+5$ simple teeth plus one sensory seta, inner set bearing two teeth slightly serrate, median portion bearing three short setae. Maxilla (Fig. 4E) of two lobes, inner lobe rounded, covered with thick setae, outer lobe covered with thin setae. Maxilliped (Fig. 4F) basis with rounded outer margin, palp proximal article triangular without setae; endite rectangular, bearing five apical and two subapical penicils.

UROPOD. As in Fig 3G.

Pereopods. Pereopod 1 (Fig. 5A) basis with triangular latero-apical process. Pereopod 7 (Fig. 5B) propodus slightly inflated; dactylus of one claw, dactylar seta stout, not surpassing claw and bearing several small sensory setae on median to apical portion.

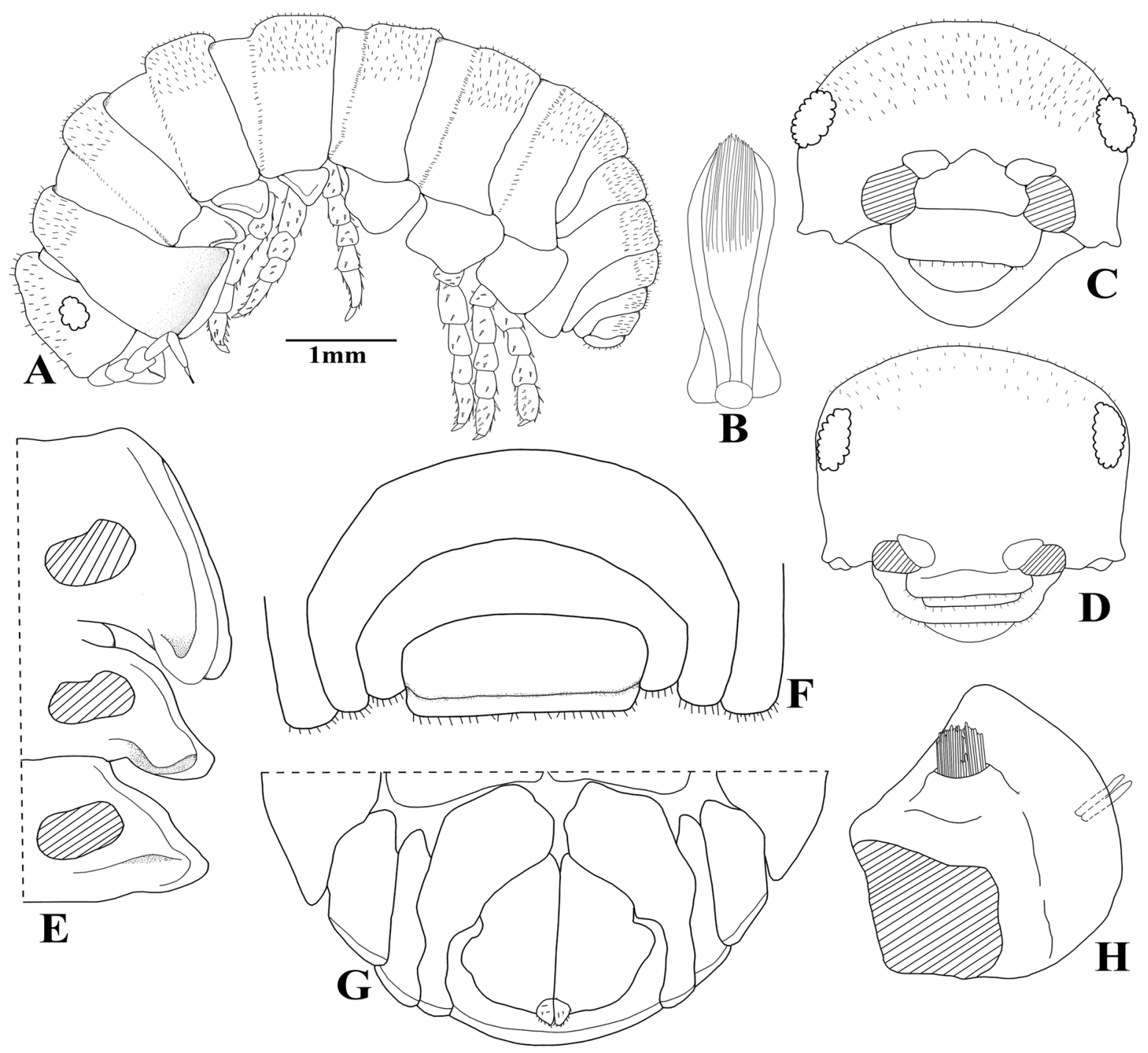

Fig. 3. Tylos negroi López-Orozco, Carpio-Díaz \& Campos-Filho sp. nov., paratype, đ (CDUCCRU 128). A. Habitus, lateral view. B. Dorsal scale-seta. C. Cephalon, frontal view. D. Cephalon, dorsal view. E. Epimera of pereonites 1-3, ventral view. F. Pleonites 4, 5 and telson, dorsal view. G. Pleon, ventral view. H. Antennula. 


\section{Male}

Pereopods 1 and 7. Without any sexual dimorphism (Fig. 5A-B).

Pleopods. Pleopod 2 exopod rectangular (Fig. 5C) with respiratory folds; endopod with distal portion slightly directed inwards, apex covered with cleft scales of 2-4 branches (Fig. 5C).

\section{Remarks}

Presently, the genus Tylos has a worldwide distribution and comprises 21 coastal species (Schmalfuss \& Vergara 2000; Schmalfuss 2003). In Colombia, only T. niveus Budde-Lund, 1885 was recorded from the Caribbean region (Carpio-Díaz et al. 2016). Tylos negroi sp. nov. can be distinguished from all species of the genus by the shape of the ventral phylacomera 5. Moreover, it differs from T. niveus in the pereonite 1 epimeron having the inner lobe of the schisma surpassing the outer lobe (vs inner lobe not surpassing outer lobe) and the pereopod 7 propodus being inflated (vs not inflated).

\section{Distribution}

Presently known only from Isla Grande, Cartagena de Indias, Colombia.
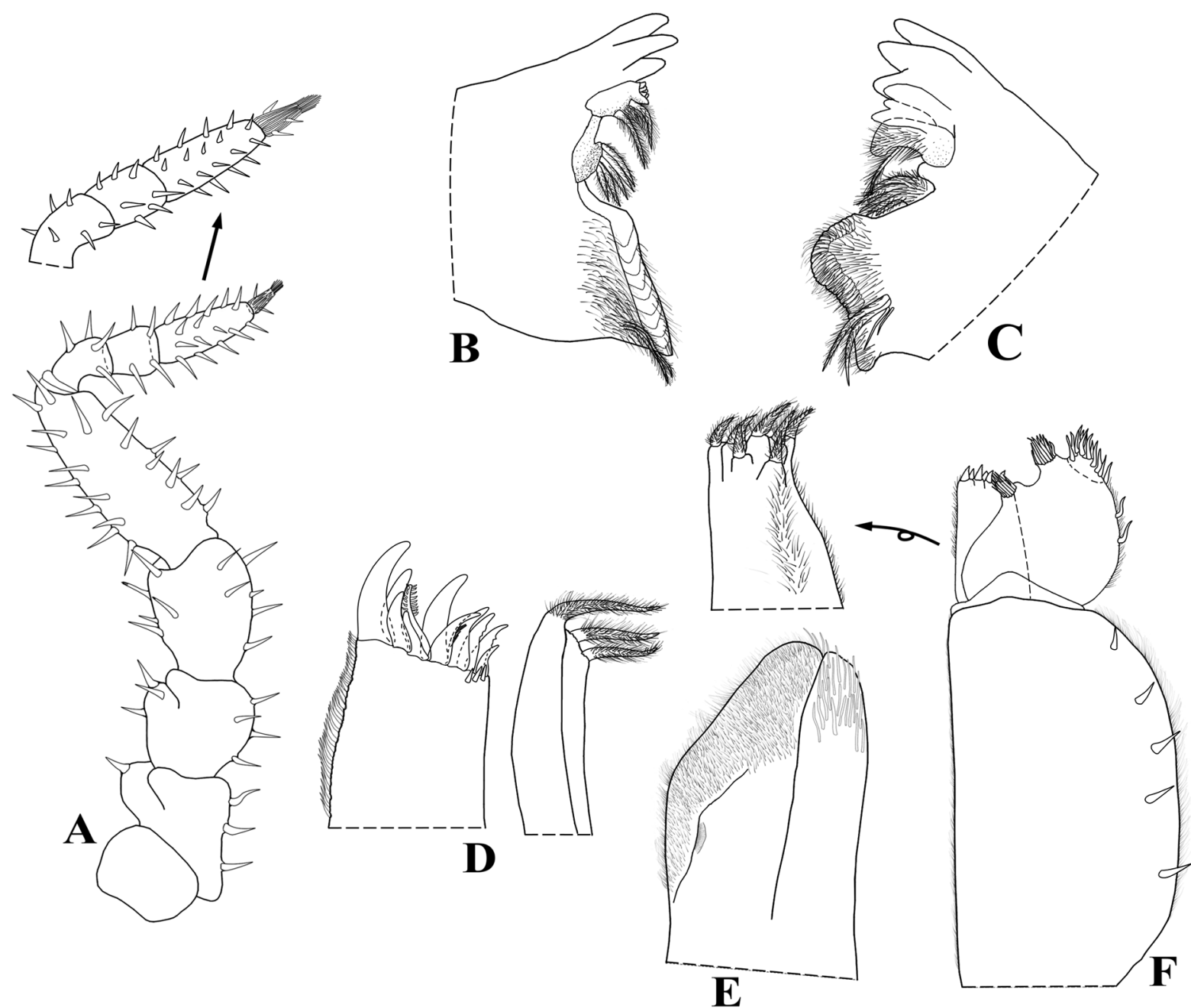

Fig. 4. Tylos negroi López-Orozco, Carpio-Díaz \& Campos-Filho sp. nov., paratype, $q$ (CDUCCRU 129). A. Antenna. B. Left mandible. C. Right mandible. D. Maxillula. E. Maxilla. F. Maxilliped. 


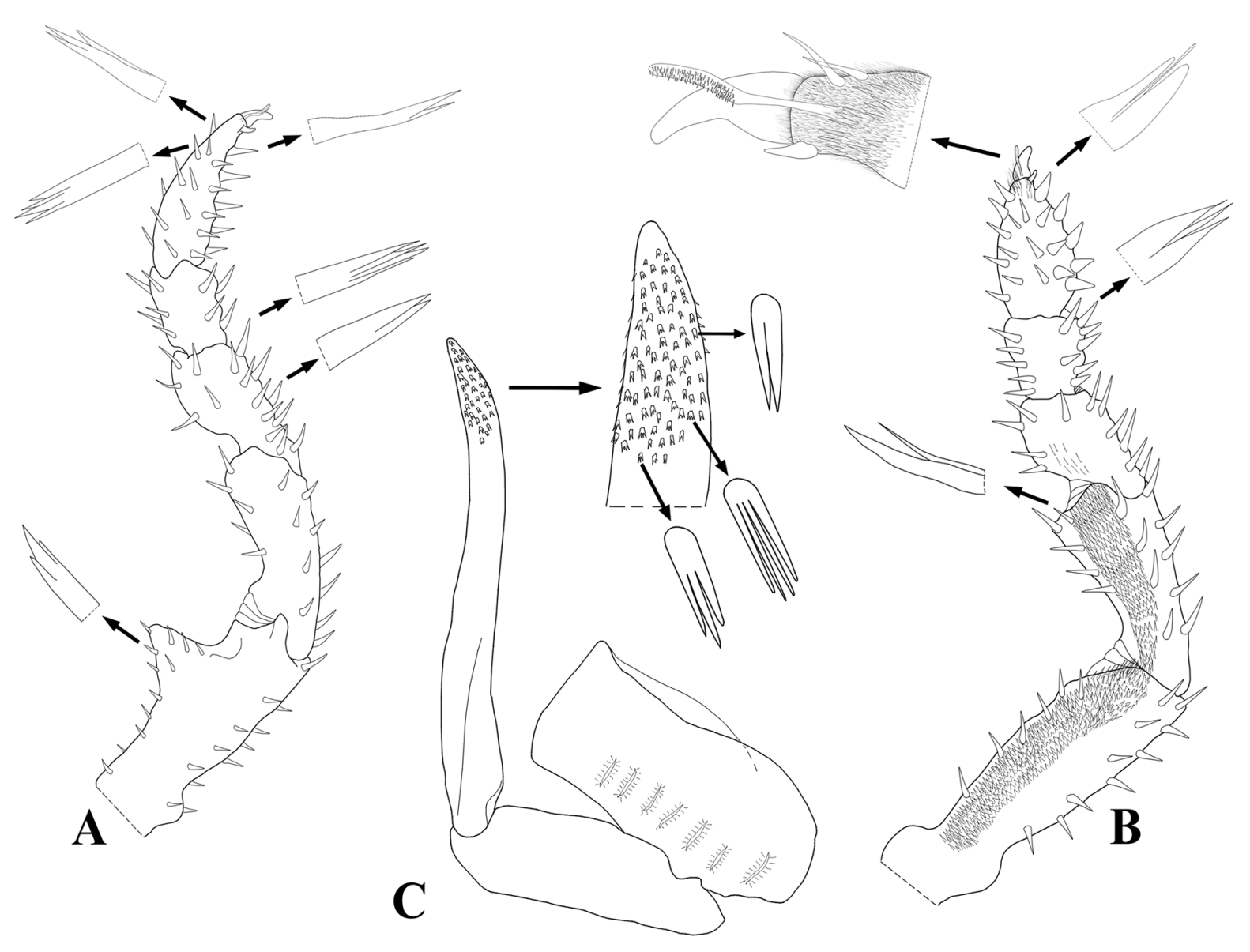

Fig. 5. Tylos negroi López-Orozco, Carpio-Díaz \& Campos-Filho sp. nov., paratype, ô (CDUCCRU 128). A. Pereopod 1. B. Pereopod 7. C. Pleopod 2.

Family Stenoniscidae Budde-Lund, 1904

Genus Stenoniscus Aubert \& Dollfus, 1890

Stenoniscus nestori López-Orozco, Taiti \& Campos-Filho sp. nov. urn:1sid:zoobank.org:act:045F7904-E6DE-4912-9073-1473A522FAC7

Figs 1, 2C, 6-8

\section{Etymology}

The new species is named after Dr Nestor Hernando Campos, for his contribution to the knowledge of Crustacea from Colombia.

\section{Material examined}

\section{Holotype}

COLOMBIA - Bolívar, Cartagena de Indias, Islas del Rosario, Isla Grande $\bullet ~ \hat{~(p a r t s ~ i n ~}$

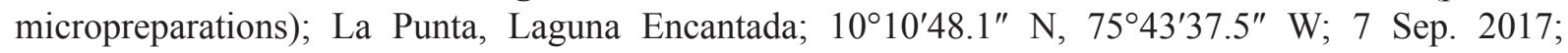
C.M. López-Orozco, R. Borja-Arrieta and Y.M. Carpio-Díaz leg.; CUDC-CRU 185. 


\section{Paratypes}

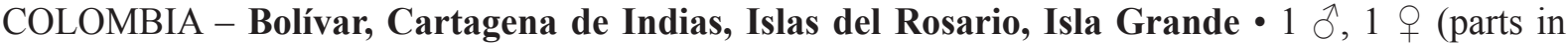
micropreparations); same collection data as for holotype; CUDC-CRU 186 • 2 q $q$; same collection data as for holotype; CUDC-CRU $187 \bullet 1$ \&; same locality and collectors as for holotype; 24 Aug. 2017; CUDC-CRU 188.

\section{Description}

MeAsurements. Maximum body length: male $1.8 \mathrm{~mm}$; female $2.4 \mathrm{~mm}$.

BoDy. Body pigments absent (Fig. 2C). Body (Fig. 6A-C) slender, about four times as long as wide, parallel sides. Dorsal surface bearing ribs and tubercles (Fig. 6A-C, E-G), as follows: cephalon with two tubercles on anterior portion and three on posterior portion; pereonite 1 with two transversal ribs; pereonites 1-4 with three longitudinal ribs (middle rib split in two on pereonites 2 and 3), one lateral tubercle and one tubercle between two lateral ribs per side; pereonites 5-7 with two longitudinal ribs and one lateral tubercle per side; pleonites $2-5$ and telson with two paramedian tubercles. Dorsum bearing rectangular scale-setae with fringed apex (Fig. 6D).

CEPHALON. Sub-rectangular (Fig. 6E-F), median lobe triangular, lateral lobes well-developed, directed frontwards, not surpassing median lobe; eyes absent.

Pereon. Epimera of pereonites 2-7 laterally grooved (Fig. 6B). Pereonites $4-5$ ventrally with lateral sternal thickenings small, triangular; pereonites 6 and 7 ventrally with sub-rectangular sternal plates (Fig. 6C).

Pleon. Pleonite 2 dorsally visible, 3-5 with rectangular epimera (Fig. 6A-C). Telson (Fig. 6G) trapezoidal, distal margin broadly rounded.

Antennula. Composed of two articles (Fig. 6H), proximal article stout with shield-like projection on distal margin, distal article comma-shaped bearing two distal aesthetascs.

ANTENNA. Short (Fig. 6I), peduncle articles more or less subequal in length; flagellum of two articles, distal article twice as long as proximal article, bearing two lateral aesthetascs.

MouTH. Mandibles with molar penicil consisting of two plumose setae, left mandible (Fig. 7A) with two penicils on incisor process, right mandible (Fig. 7B) with one penicil. Maxillula (Fig. 7C) inner endite with two short apical penicils; outer endite bearing $4+4$ teeth, inner set with two teeth apically cleft. Maxilla (Fig. 7D) of two rounded lobes, inner lobe bearing three thick setae. Maxilliped (Fig. 7E) basis with sparse setae; endite stout, distal margin rounded, bearing thin setae, one large penicil inserted near medial margin.

UROPOD. Protopod stout and conical, exopod short, bearing two long apical setae, endopod inserted proximally (Fig. 7F).

Pereopods. Pereopods 1-7 short, stout, merus to propodus bearing sparse setae on sternal margins; pereopod 1 carpus with distal seta fringed at apex; dactylus of two claws, inner claw very short, ungual seta simple, not surpassing outer claw, dactylar seta stout, reaching distal margin of outer claw, apex bearing many small setae.

\section{Male}

Pereopods 1 And 7. Without sexual dimorphism (Fig. 8A-B).

Pleopods. Pleopod 1 exopod absent; endopod (Fig. 8C) enlarged on proximal portion, distal portion tapering. Pleopod 2 (Fig. 8D) exopod triangular, inner margin grooved, bearing one strong seta; endopod 

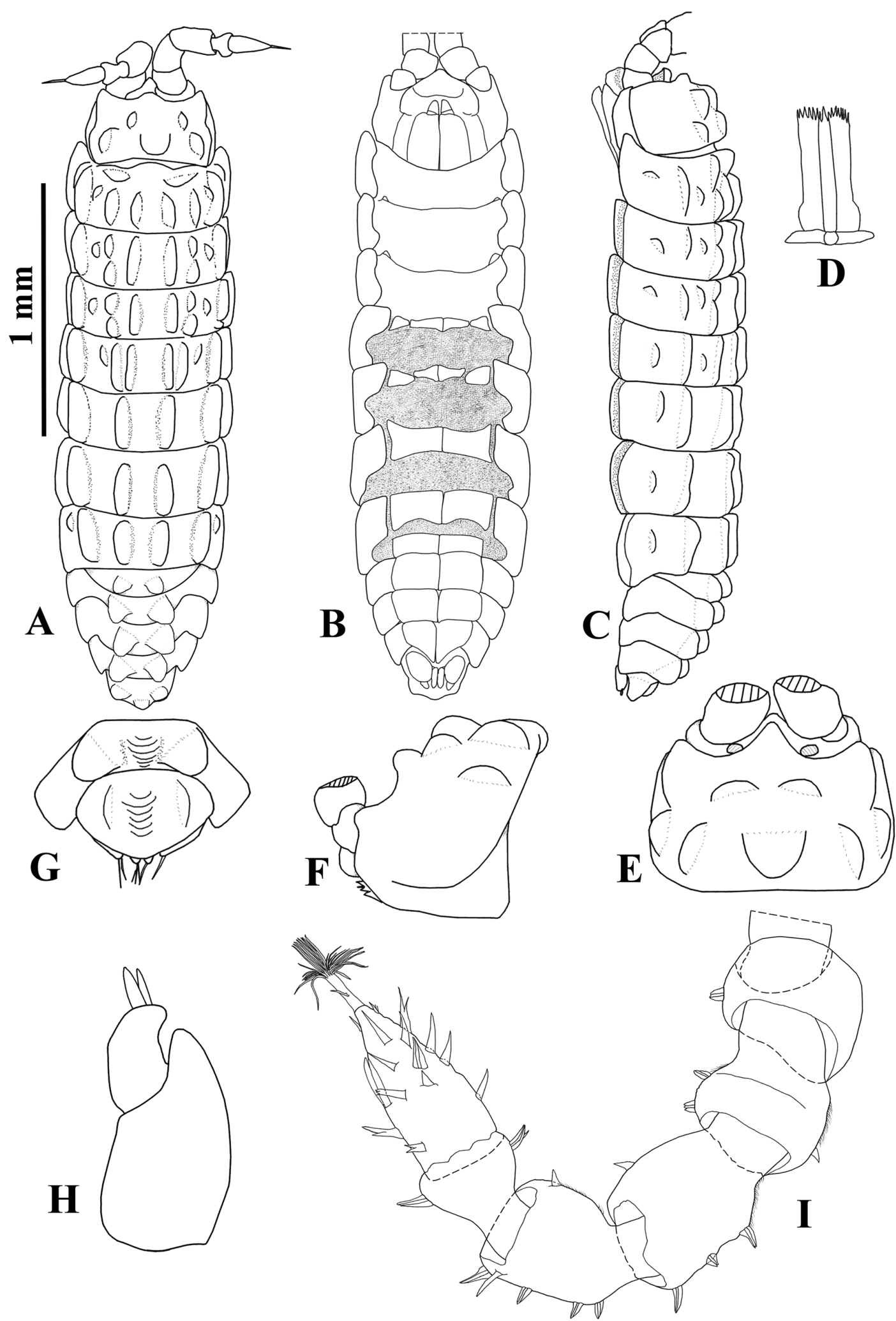

Fig. 6. Stenoniscus nestori López-Orozco, Taiti \& Campos-Filho sp. nov., paratype, $\widehat{o}$ (CDUCCRU 186). A. Habitus, dorsal view. B. Habitus, ventral view. C. Habitus, lateral view. D. Dorsal scale-seta. E. Cephalon, dorsal view. F. Cephalon, lateral view. G. Pleonite 5 and telson, dorsal view. H. Antennula. I. Antenna. 
about twice as long as exopod. Pleopod 3 and 4 exopods (Fig. 8E-F) sub-quadrangular, inner margin grooved, distal margin slightly serrate. Pleopod 5 exopod (Fig. 8G) sub-rectangular, inner margin slightly serrate, distal margin straight, bearing one seta.

\section{Remarks}

Presently, Stenoniscus comprises four species (Schmalfuss 2003): S. pleonalis Aubert \& Dollfus, 1890 from the northern coasts of the Mediterranean east to the Aegean, Bermuda, Bulgaria, Madeira and Mexico; S. carinatus Silvestri, 1897 from coastal areas of Croatia, Italy, Portugal and Spain; S. aenariensis (Verhoeff, 1942) and S. plutonis (Verhoeff, 1942) from Ischia Island, Italy, both most

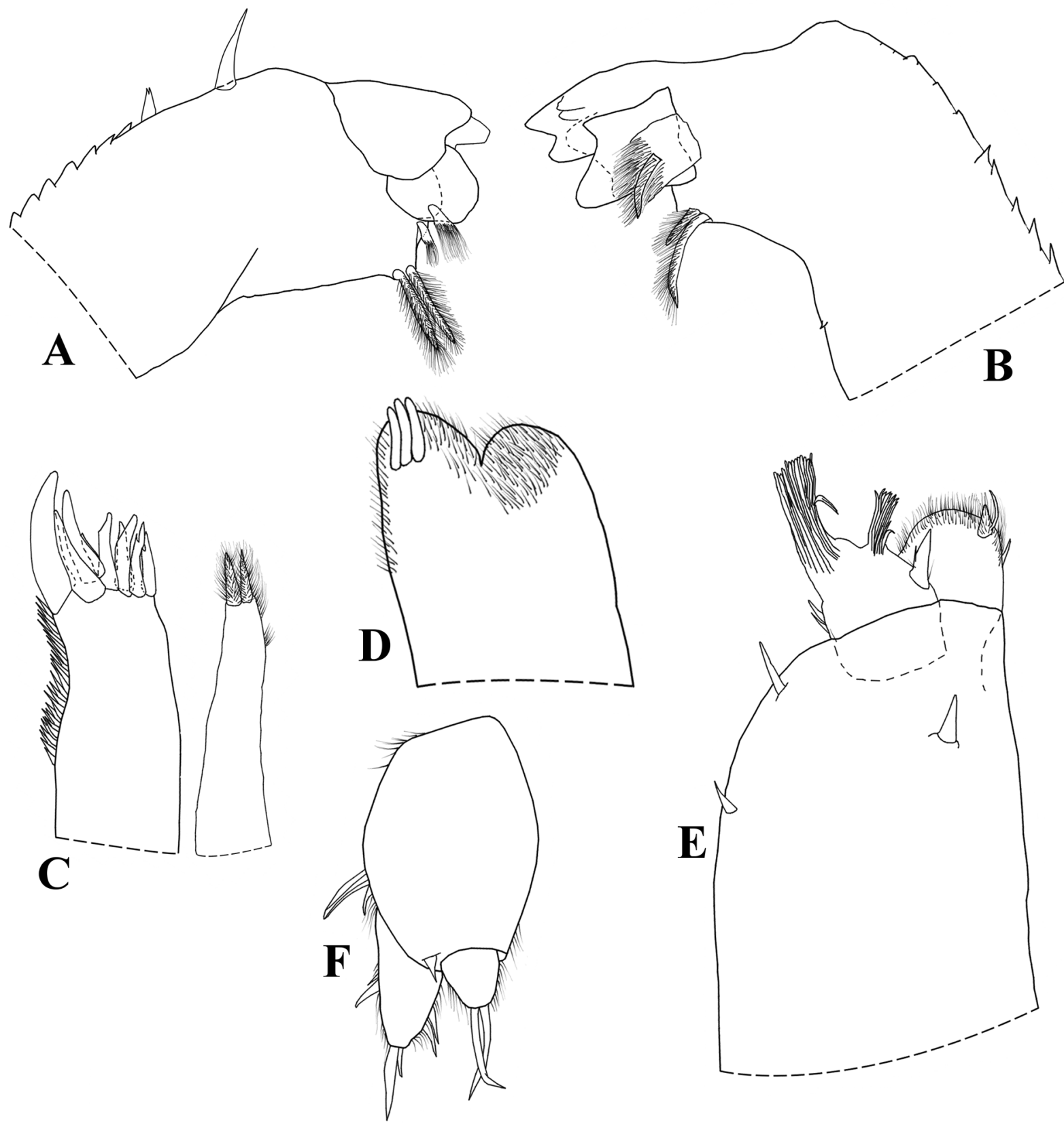

Fig. 7. Stenoniscus nestori López-Orozco, Taiti \& Campos-Filho sp. nov., paratype, $q$ (CDUCCRU 186). A. Left mandible. B. Right mandible. C. Maxillula. D. Maxilla. E. Maxilliped. F. Uropod. 


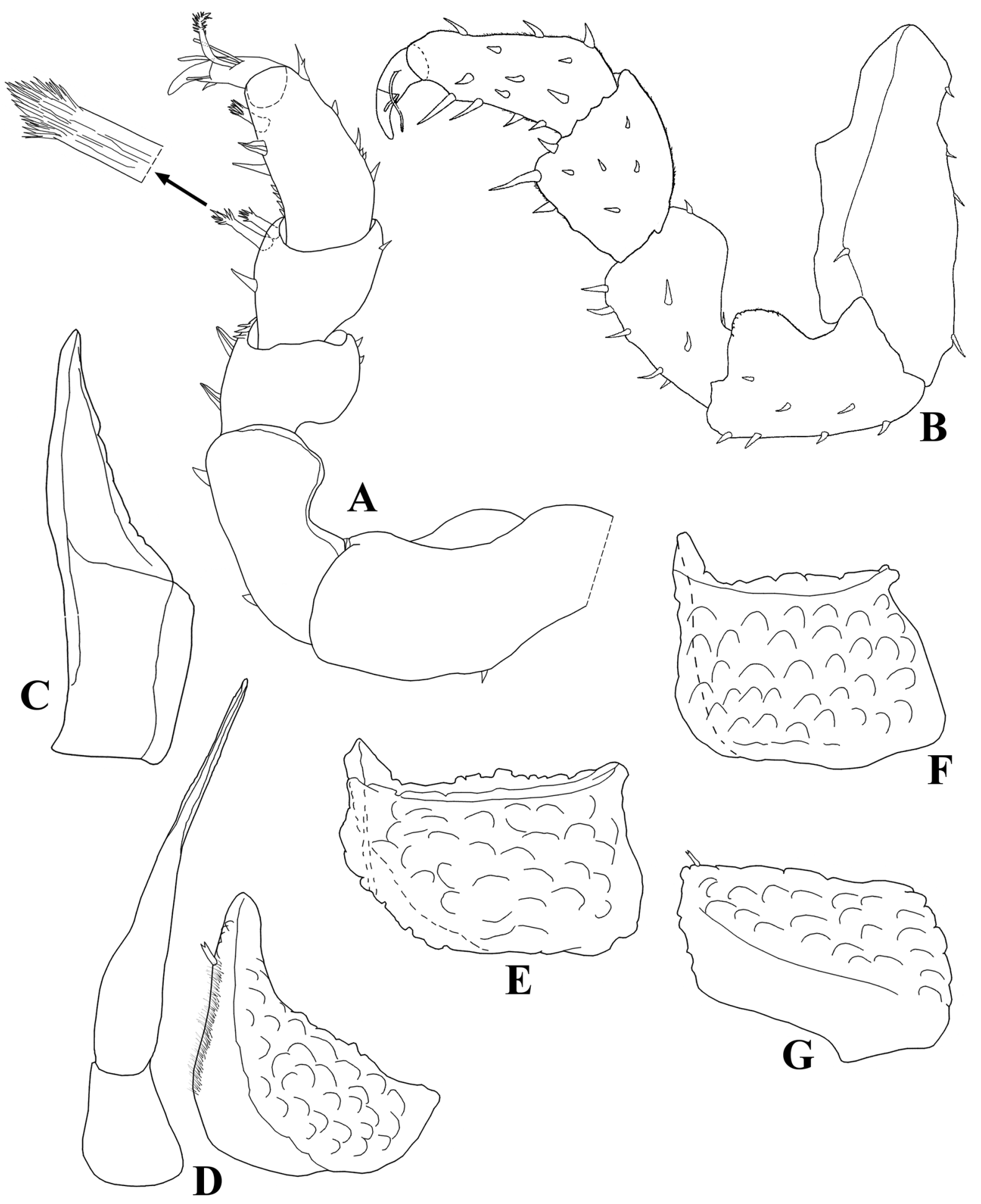

Fig. 8. Stenoniscus nestori López-Orozco, Taiti \& Campos-Filho sp. nov., paratypes, $ぇ \widehat{~}$ (CDUCCRU 185 and CDUC-CRU 186). A. Pereopod 1. B. Pereopod 7. C. Pleopod 1 endopod. D. Pleopod 2. E. Pleopod 3 exopod. F. Pleopod 4 exopod. G. Pleopod 5 exopod. 
probably junior synonyms of $S$. pleonalis according to the short descriptions by Verhoeff (1942). The genus can be defined by animals of reduced size (up to $3.5 \mathrm{~mm}$ ), body slender with lateral sides parallel, dorsum bearing longitudinal ribs and tubercles, sometimes reduced, epimera of pereonites 2-7 with lateral margins grooved, pereonites $4-5$ ventrally with lateral sternal thickenings and 6-7 with sternal plates, antennula of two articles, pleonite 1 absent, uropods of conical shape, pleopod exopods without respiratory organs, and pleopod 1 absent on females (see Vandel 1962; Schmidt 2003).

Stenoniscus nestori López-Orozco, Taiti \& Campos-Filho sp. nov. is morphologically similar to Stenoniscus carinatus, from which it differs mainly in the number and disposition of the dorsal ribs and tubercles on the cephalon and pereonites (compare Fig. 6A-B with Schmidt 2003: fig. 67 and Taiti \& Ferrara 1982: fig. 6a for $S$. carinatus). The new species is readily distinct from Stenoniscus pleonalis in having a strong dorsal ornamentation (vs very weak) and lacking the tomentose appearance due to long dorsal scale-setae (see Vandel 1944: fig. 1a-c).

\section{Distribution}

Presently known only from Isla Grande, Cartagena de Indias, Colombia.

Family Detonidae Budde-Lund, 1904

\section{Remarks}

The family Detonidae Budde-Lund, 1904 comprises 39 littoral species in the genera Armadilloniscus Uljanin, 1875 (32 spp.), Deto Guérin-Méneville, 1836 (5 spp.) and Detonella Lohmander, 1927 (2 spp.), including two dubious species, Armadilloniscus minutus Uljanin, 1875 and Deto spinicornis Brandt, 1851 (Schultz 1984; Paoletti \& Stinner 1989; Taiti \& Ferrara 1989; Schmidt 2002; Schmalfuss 2003; Schmidt \& Leistikow 2004; WoRMS 2020b). The family can be characterized by animals having a clinger habitus (sensu Schmalfuss 1984), cephalon with well-developed lateral lobes, dorsal surface more or less tuberculated or with longitudinal ridges, exopods of pleopods 1-5 without respiratory structures and lateral margins covered with thin setae conferring a fringe-like appearance (see Taiti \& Ferrara 1989; Schmidt 2002).

Recently, Reinoso-Flórez et al. (2016) recorded the family from Páramo de Estambul (Tolima), Colombia. However, after the re-examination of the material deposited at Colección Zoológica de la Universidad del Tolima (CZUT-IT 1423-1426, see Reinoso-Flórez et al. 2016), the specimens belong to the families Styloniscidae and Philosciidae, and therefore, our work constitutes the first record of the family in the country.

Genus Armadilloniscus Uljanin, 1875

Armadilloniscus caraibicus Paoletti \& Stinner, 1989

Figs 1, 2D, 9

Armadilloniscus caraibicus Paoletti \& Stinner, 1989: 73, figs 6-12.

\section{Additional reference}

Schmidt (2002).

\section{Material examined}

COLOMBIA - Bolívar, Cartagena de Indias, Islas del Rosario, Isla Grande • 2 $\uparrow+$; Paraíso Secreto; $10^{\circ} 10^{\prime} 15.9^{\prime \prime}$ N, 7544'38.8" W; 4 Apr. 2018; C.M. López-Orozco, R. Borja-Arrieta and K. Meza leg.;

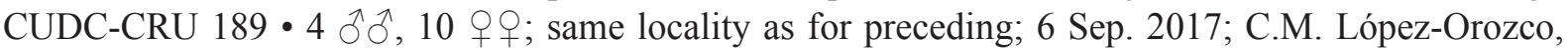


Y.M. Carpio-Díaz and R. Borja-Arrieta leg.; CUDC-CRU 190 • 1 q; Caño Ratón; 10¹0'33.4" N,

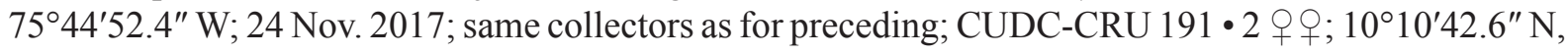
7544'52.6" W; same collection data as for preceding; CUDC-CRU 192.

\section{Remarks}

Paoletti \& Stinner (1989) described A. caraibicus from Parque Marrocoy, Falcón State, Venezuela. In the description, no sexual dimorphism was noted in the dorsal ornamentation. However, the male specimens show four dorsal tubercles on pleonite 2, while females have only two (see Fig. 9 and Paoletti \& Stinner 1989: fig. 11).

\section{Distribution}

Venezuela: Coralline cays of the Parque Natural Morrocoy (Paoletti \& Stinner 1989), and north coast of the Península de Paria (Schmidt 2001). First record for Colombia.

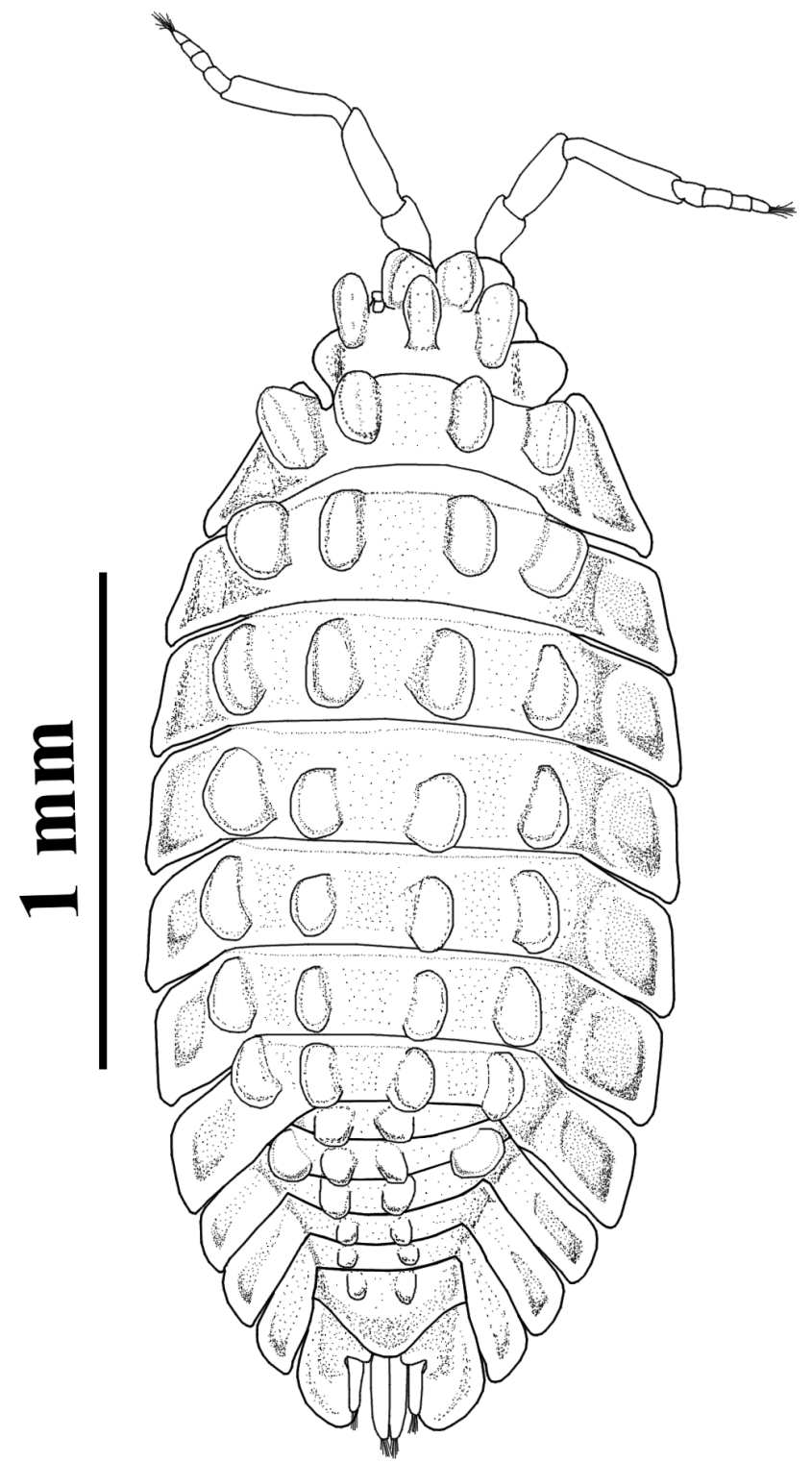

Fig. 9. Armadilloniscus caraibicus Paoletti \& Stinner, 1989, đ̊ (CUDC-CRU 190). Habitus, dorsal view. 
Armadilloniscus luisi Carpio-Díaz, Taiti \& Campos-Filho sp. nov. urn:lsid:zoobank.org:act:88600E5C-BFF9-49BA-976C-8853E33A6E58

Figs 1, 2E, 10-12

\section{Etymology}

The new species is named after Mr Luis Felipe Arrieta Zúñiga, for his interest in nature and support to Ricardo Borja-Arrieta as a biologist.

\section{Material examined}

\section{Holotype}

COLOMBIA - Bolívar, Cartagena de Indias, Islas del Rosario, Isla Grande • ${ }^{\wedge}$; Laguna del Silencio, El Silencio; 10¹0'35.4" N, 7544'26" W; 24 Aug. 2017; C.M. López-Orozco, Y.M. Carpio-Díaz and R. Borja-Arrieta leg.; CUDC-CRU 193.

\section{Paratypes}

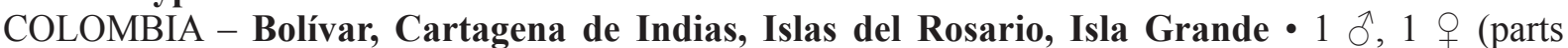

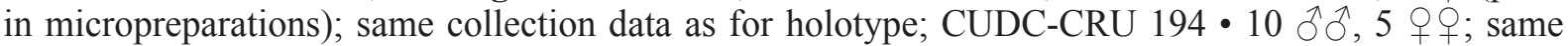
collection data as for holotype; CUDC-CRU 195 • 1 \% ; $10^{\circ} 10^{\prime} 32.9^{\prime \prime} \mathrm{N}, 75^{\circ} 44^{\prime} 27.3^{\prime \prime} \mathrm{W}$; same date and collectors as for holotype; CUDC-CRU $206 \bullet^{\prime}$; ; $10^{\circ} 10^{\prime} 33.5^{\prime \prime} \mathrm{N}, 75^{\circ} 44^{\prime} 26.9^{\prime \prime} \mathrm{W}$; same date and collectors as for holotype; CUDC-CRU $207 \cdot 10^{\prime} ; 10^{\circ} 10^{\prime} 35^{\prime \prime} \mathrm{N}, 75^{\circ} 44^{\prime} 26.4^{\prime \prime} \mathrm{W}$; same date and collectors as for holotype; CUDC-CRU 208 1 1 $0^{\prime} ; 10^{\circ} 10^{\prime} 34.8^{\prime \prime} \mathrm{N}, 75^{\circ} 44^{\prime} 26.6^{\prime \prime} \mathrm{W}$; same date and collectors as

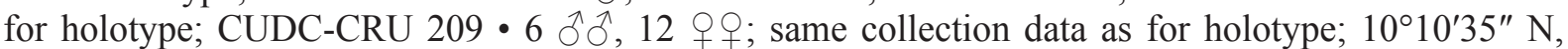

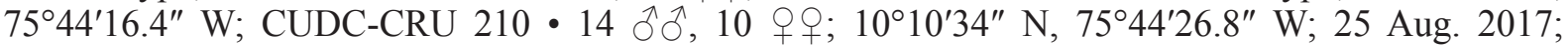
same locality and collectors as for holotype; CUDC-CRU 211 - $3{ }^{\lambda} \delta^{\lambda}$; La Punta, Laguna Encantada; $10^{\circ} 10^{\prime} 48.4^{\prime \prime}$ N, 7543'38.4" W; 25 Aug. 2017; C.M. López-Orozco, Y.M. Carpio-Díaz and R. BorjaArrieta leg.; CUDC-CRU $196 \bullet 1 \mathrm{O}^{\top}$; same locality as for preceding; $10^{\circ} 10^{\prime} 47.72^{\prime \prime} \mathrm{N}, 75^{\circ} 43^{\prime} 40.09^{\prime \prime} \mathrm{W}$; same date and collectors as for holotype; CUDC-CRU $197 \bullet 1$ O, 1 q; same locality as for preceding; $10^{\circ} 10^{\prime} 48^{\prime \prime} \mathrm{N}, 75^{\circ} 43^{\prime} 39.3^{\prime \prime} \mathrm{W}$; same date and collectors as for holotype; CUDC-CRU 198 • 1 q; same locality as for preceding; $10^{\circ} 10^{\prime} 47.7^{\prime \prime} \mathrm{N}, 75^{\circ} 43^{\prime} 39.93^{\prime \prime} \mathrm{W}$; same date and collectors as for holotype; CUDC-CRU 199 • 2 ô $^{\lambda}, 3$ 우; same locality as for preceding; $10^{\circ} 10^{\prime} 48.3^{\prime \prime} \mathrm{N}, 75^{\circ} 43^{\prime \prime} 38.9^{\prime \prime} \mathrm{W}$; same date and collectors as for holotype; CUDC-CRU $200 \bullet 3$ 우; same locality as for preceding; $10^{\circ} 10^{\prime} 48.1^{\prime \prime} \mathrm{N}$, $75^{\circ} 43^{\prime} 39.1^{\prime \prime} \mathrm{W}$; same date and collectors as for holotype; CUDC-CRU $201 \bullet 2$ 우; same locality as for preceding; $10^{\circ} 10^{\prime} 48.1^{\prime \prime} \mathrm{N}, 75^{\circ} 43^{\prime} 37.5^{\prime \prime} \mathrm{W}$; same date and collectors as for holotype; CUDC-CRU 202 • $4{ }^{\lambda}{ }^{\lambda}, 4$ 우; same locality as for preceding; $10^{\circ} 10^{\prime} 47.72^{\prime \prime} \mathrm{N}, 75^{\circ} 43^{\prime} 40.09^{\prime \prime} \mathrm{W}$; same date and collectors

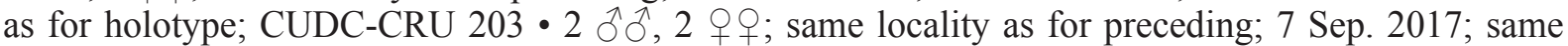
date and collectors as for holotype; CUDC-CRU $204 \cdot 3{ }^{\lambda}{ }^{\lambda}, 4$ o 9 ; Laguna La Charca; $10^{\circ} 10^{\prime} 47.8^{\prime \prime} \mathrm{N}$, 7544'0.4" W; 7 Sep. 2017; C.M. López-Orozco, Y.M. Carpio-Díaz and R. Borja-Arrieta leg.; CUDCCRU 205.

\section{Description}

Measurements. Maximum length: male $2.5 \mathrm{~mm}$; female $3.1 \mathrm{~mm}$.

BoDy. Color brown with usual pale muscle spots; antennae brown with pale flagellum (Fig. 2E). Body elongated and elliptical-shaped (Fig. 10A, H). Dorsal surface bearing elongated scale-setae (Fig. 10B). Dorsum covered with broad tubercles (Fig. 10A, C-E, H): cephalon bearing seven tubercles in two rows, anterior row with four and posterior row with three; $\delta$ pereonites $1-3$ with one row of 10 tubercles, 4-7 with one row of eight tubercles; 9 pereonites 1,5 and 6 with one row of 10 tubercles, 2-4 and 7 with one row of eight tubercles; $\delta$ pleonites $1-5$ and telson with two paramedian tubercles, pleonite 2 with two broad tubercles at sides, pleonite 3 with two small additional tubercles; 9 pleonites $1-5$ and telson with two paramedian tubercles, pleonites 2 and 3 with two additional small tubercles at sides.

Cephalon. Lateral lobes well developed and directed outwards, median lobe triangular, slightly surpassing distal margin of lateral lobes, frontal and suprantennal lines absent; eyes consisting of four ommatidia (Fig. 10C-D). 


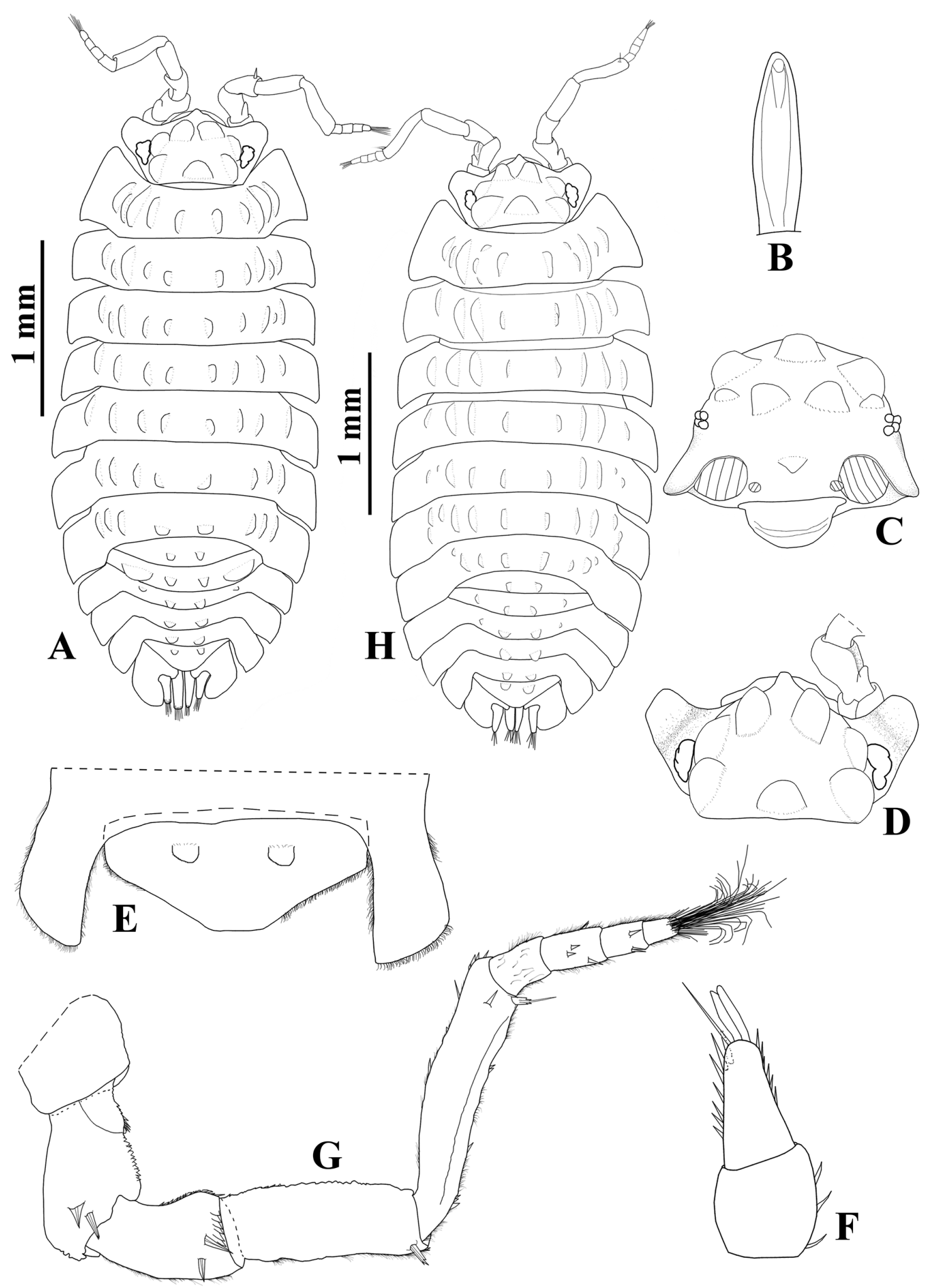

Fig. 10. Armadilloniscus luisi Carpio-Díaz, Taiti \& Campos-Filho sp. nov. A-G. Paratype, ô (CUDCCRU 194). A. Habitus, dorsal view. B. Dorsal scale-seta. C. Cephalon, frontal view. D. Cephalon, dorsal view. E. Pleonite 5 and telson. F. Antennula. G. Antenna. H. Paratype, $q$ (CDUC-CRU 194), habitus, dorsal view. 
Pleon. Outline continuous with that of pereonite 7, epimera of pleonites 3-5 rectangular (Fig. 10A, E, $\mathrm{H})$. Telson (Fig. 10E) triangular, lateral margins almost straight, distal part truncate and not surpassing distal margin of pleonite 5 epimera.

Antennula. Composed of two articles, second article bearing a few lateral setae, distal margin bearing one flagellar seta and two aesthetascs (Fig. 10F).

ANTENNA. When extended posteriorly slightly surpassing pereonite 1, flagellum of four articles (Fig. 10G).

Mouth. Mandibles with molar penicil of several plumose setae, left mandible with $2+1$ penicils (Fig. 11A), right with 1+1 penicils (Fig. 11B). Maxillula (Fig. 11C) inner endite with two penicils; outer endite of $4+8$ teeth, five of them pectinated, and one slender stalk between outer and inner set, outer distal margin bearing fringe of long thin setae. Maxilla (Fig. 11D) with lobes fused, inner middle portion with five long setae, distal margin rounded, bearing several thin and thick setae. Maxilliped (Fig. 11E) palp bearing two tufts of setae on first article, distal articles of palp fused, bearing several thin and thick setae; endite rectangular, inner margin bearing fringe of long thin setae plus four long thick setae, distal margin bilobed, bearing broad rounded penicil with long thick setae.

UROPOD. Protopod enlarged with distal margin rounded, exopod not surpassing protopod, endopod longer than exopod (Fig. 11F).

Pereopods. Pereopods 1-7 stout, merus to propodus bearing sparse setae on sternal margin, carpus 1 with strong distal seta bearing long sensilla, dactylus with very long ungual seta, dactylar seta elongated, apically cleft and plumose.

\section{Male}

Pereopods 1 and 7. Without any sexual modifications (Fig. 12A-B).

Genital PaPILLA. Ventral shield triangular, papilla slightly cleft at apex, bearing small setae (Fig. 12C).

Pleopods. Pleopod 1 (Fig. 12D) exopod ovoid; endopod three times as long as exopod, apical portion bent outwards. Pleopod 2 (Fig. 12E) exopod subtriangular; endopod with distal article flagelliform. Exopods of pleopods 3-5 as in Fig. 12F-H.

\section{Remarks}

In the Caribbean region, four species of Armadilloniscus have been recorded: A. caraibicus from Venezuela, A. ellipticus (Harger, 1878) from the Atlantic coasts of USA and Bermuda, A. ninae Schultz, 1984 from Belize, and A. steptus Schotte \& Heard, 1991 from Turks and Caicos Islands (British West Indies) (Schultz 1984; Paoletti \& Stinner 1989; Taiti \& Ferrara 1989; Schotte \& Heard 1991). For a definition of the genus see Arcangeli (1957), Vandel (1962), Taiti \& Ferrara (1989), and Schmidt (2002).

Armadilloniscus luisi Carpio-Díaz, Taiti \& Campos-Filho sp. nov. is readily distinguished from all the other species of the genus in the number and arrangement of the dorsal tubercles on the cephalon, pereon and pleon. Moreover, it can be distinguished from the other four Caribbean species in having two broad tubercles on pleonite 2 (vs small in A. caraibicus and A. steptus, absent in A. ninae), the cephalon with the median lobe triangular (vs rounded in A. caraibicus) and lateral lobes subquadrangular (vs subtriangular in A. ninae and A. steptus), eyes composed of four ommatidia (vs 4-5 in A. caraibicus, 6 in A. ellipticus and 5 in A. ninae), telson with distal margin truncate (vs rounded in A. caraibicus and A. ellipticus, triangular in A. ninae), and $\delta$ pleopod 1 exopod ovoid (vs subtriangular in A. caraibicus, A. ellipticus and A. ninae, almost rounded in A. steptus) (Paoletti \& Stinner 1989; Schultz 1984; Schotte \& Heard 1991; Garthwaite et al. 1992; Schmidt 2002). 


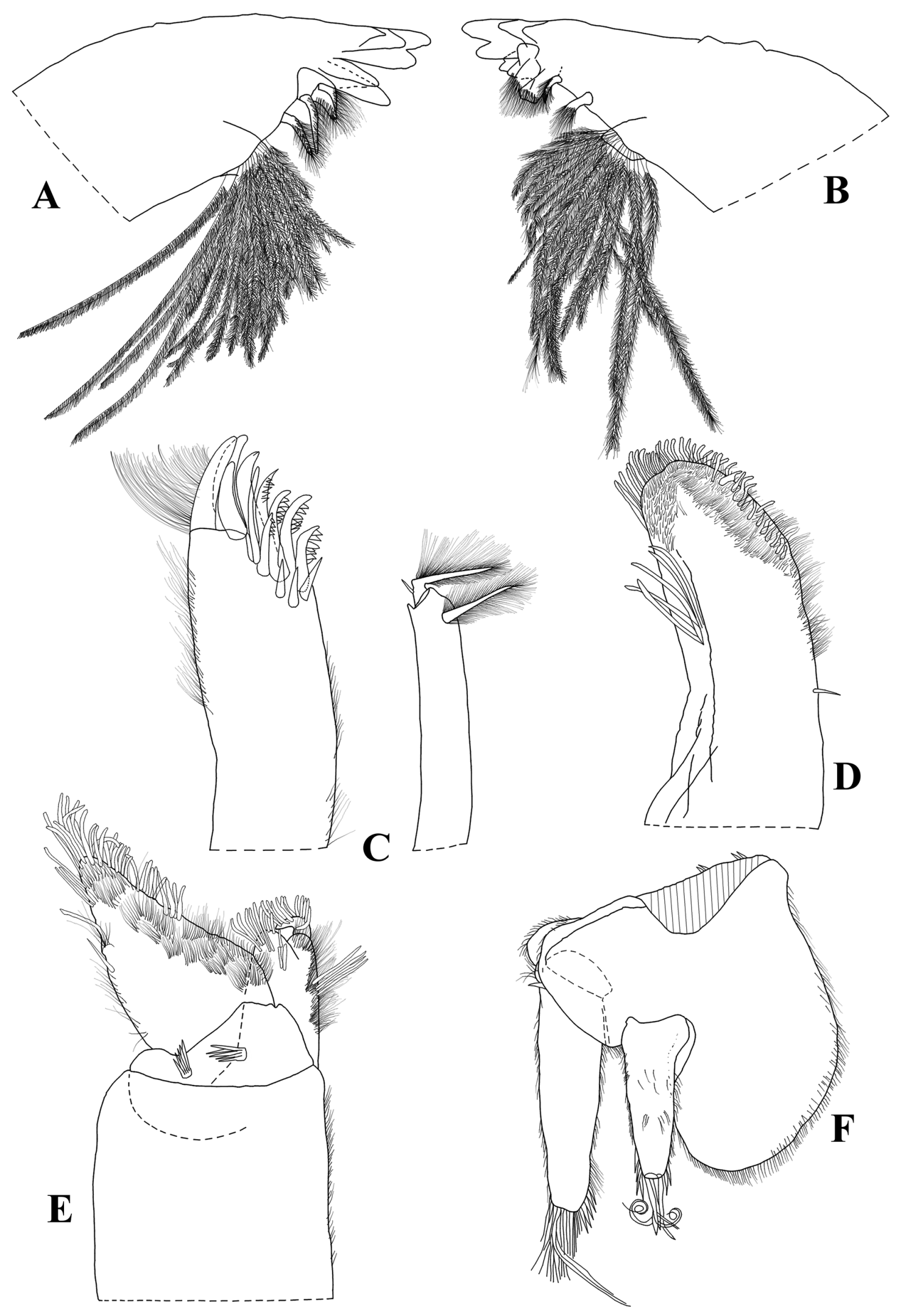

Fig. 11. Armadilloniscus luisi Carpio-Díaz, Taiti \& Campos-Filho sp. nov., paratype, $q$ (CDUCCRU 194). A. Left mandible. B. Right mandible. C. Maxillula. D. Maxilla. E. Maxilliped. F. Uropod. 


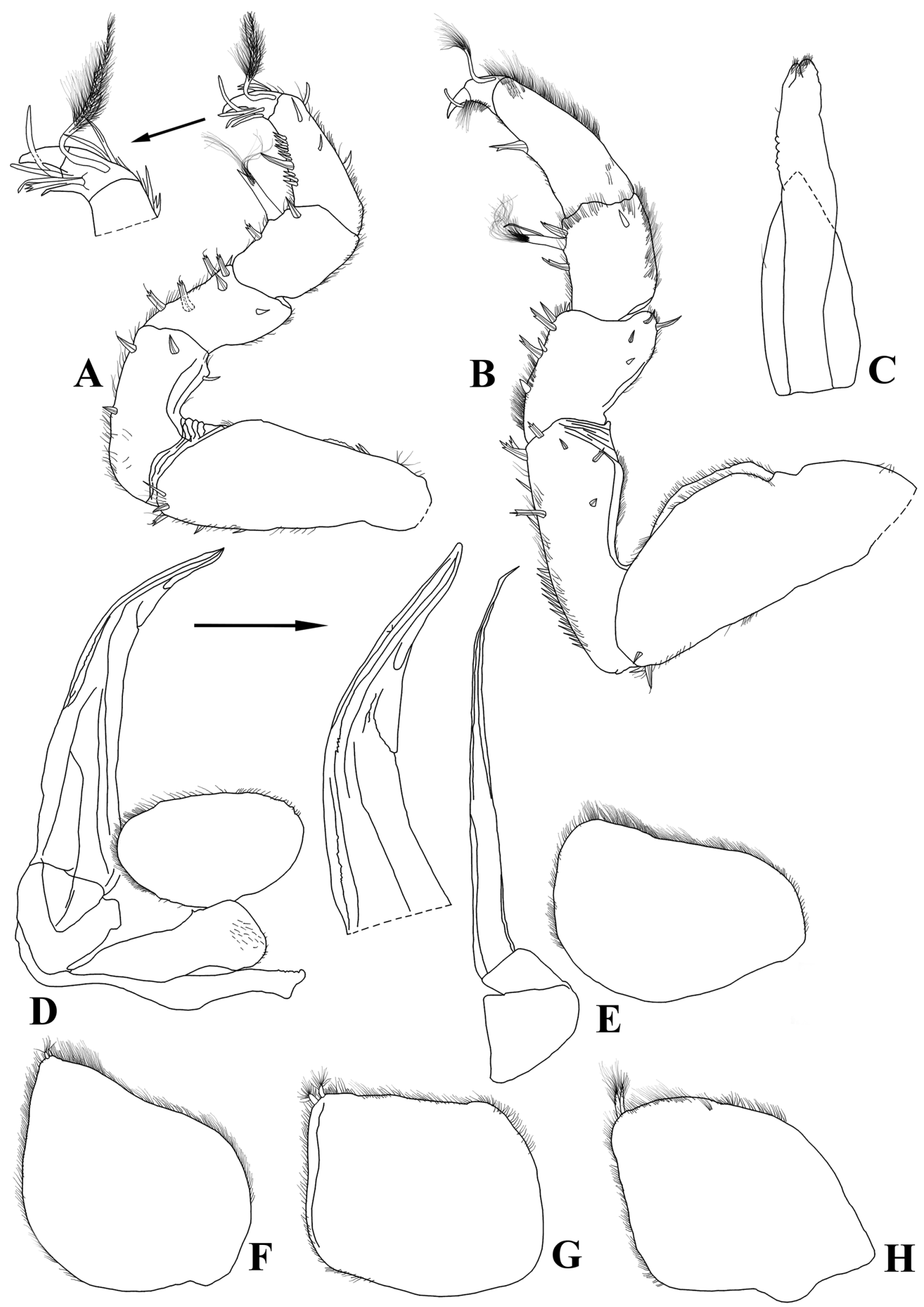

Fig. 12. Armadilloniscus luisi Carpio-Díaz, Taiti \& Campos-Filho sp. nov., paratype, § (CDUCCRU 194). A. Pereopod 1. B. Pereopod 7. C. Genital papilla. D. Pleopod 1. E. Pleopod 2. F. Pleopod 3 exopod. G. Pleopod 4 exopod. H. Pleopod 5 exopod. 


\title{
Distribution
}

Presently known only from Isla Grande, Cartagena de Indias, Colombia.

\author{
Armadilloniscus ninae Schultz, 1984
}

Figs 1, 2F, 13-14

Armadilloniscus ninae Schultz, 1984: 4, figs 1-2.

\section{Material examined}

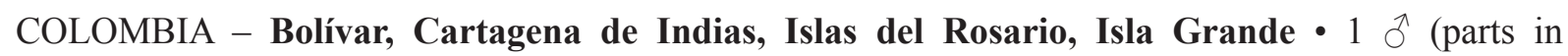
micropreparations); Paraíso Secreto; $10^{\circ} 10^{\prime} 15.9^{\prime \prime}$ N, 7544'38.8" W; 24 Nov. 2017; C.M. LópezOrozco leg.; CUDC-CRU $212 \bullet 1 \hat{\jmath}, 4$ 우; same collection data as for preceding; CUDC-CRU 214 • $21 \widehat{\jmath} \widehat{\jmath}, 61$ 우; same locality as for preceding; 4 Apr. 2018; C.M. López-Orozco, R. Borja-Arrieta and K. Meza leg.; CUDC-CRU 213 • 3 9 \%; same locality as for preceding; 6 Sep. 2017; C.M. LópezOrozco leg.; CUDC-CRU $215 \cdot 1$ ภ, 6 우 (one with parts in micropreparations); Caño Ratón; $10^{\circ} 10^{\prime} 33.4^{\prime \prime} \mathrm{N}, 75^{\circ} 44^{\prime} 52.4^{\prime \prime} \mathrm{W} ; 24$ Nov. 2017; C.M. López-Orozco leg.; CUDC-CRU 216 • 5 q ; $10^{\circ} 10^{\prime} 44.91^{\prime \prime} \mathrm{N}, 75^{\circ} 44^{\prime} 53.01^{\prime \prime} \mathrm{W}$; same collection data as for preceding; CUDC-CRU 217.

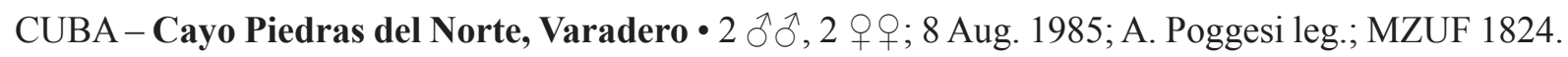

\section{Redescription}

BoDy. Color pale brown; cephalon, antennae, epimera of pereonites $1-7$, epimera of pleonites $1-5$ and uropod protopods more pigmented; pereon and pleon with median and paramedian region more depigmented (Fig. 2F). Body elongated and elliptical-shaped (Fig. 13A). Dorsal surface bearing elongated scale-setae (Fig. 13B). Cephalon and pereon covered with small tubercles (Fig. 13A, C-D): cephalon bearing six tubercles in two rows, anterior row with two and posterior row with four; pereonites $1-7$ with one row of 8 tubercles.

Cephalon. Lateral lobes well developed and directed outwards, median lobe triangular, slightly surpassing distal margin of lateral lobes, frontal and suprantennal lines absent; eyes consisting of 5 ommatidia (Fig. 13C-D).

PLEON. Outline continuous with that of pereonite 7, epimera of pleonites 3-5 rectangular (Fig. 13A, E). Telson (Fig. 13E) triangular, wider than long, lateral margins almost straight, broadly rounded apex.

Antennula. Composed of two articles, second article bearing many lateral setae, distal margin bearing one flagellar seta and two aesthetascs (Fig. 13F).

ANTENNA. When extended posteriorly slightly surpassing pereonite 1, flagellum of four articles (Fig. 13G).

BucCAL PIECEs. As in Armadilloniscus luisi sp. nov.

UROPOD. Protopod enlarged with distal margin slightly rounded, exopod not surpassing protopod, endopod longer than exopod (Fig. 13E).

Pereopods. Pereopods 1-7 stout, merus to propodus bearing sparse setae on sternal margin, carpus 1 with strong distal seta bearing long sensilla, dactylus with elongated and digitform ungual seta, dactylar seta elongated, apically cleft and plumose.

\section{Male}

PEREOPODS 1 AND 7. Without any sexual modifications (Fig. 14A-B). 


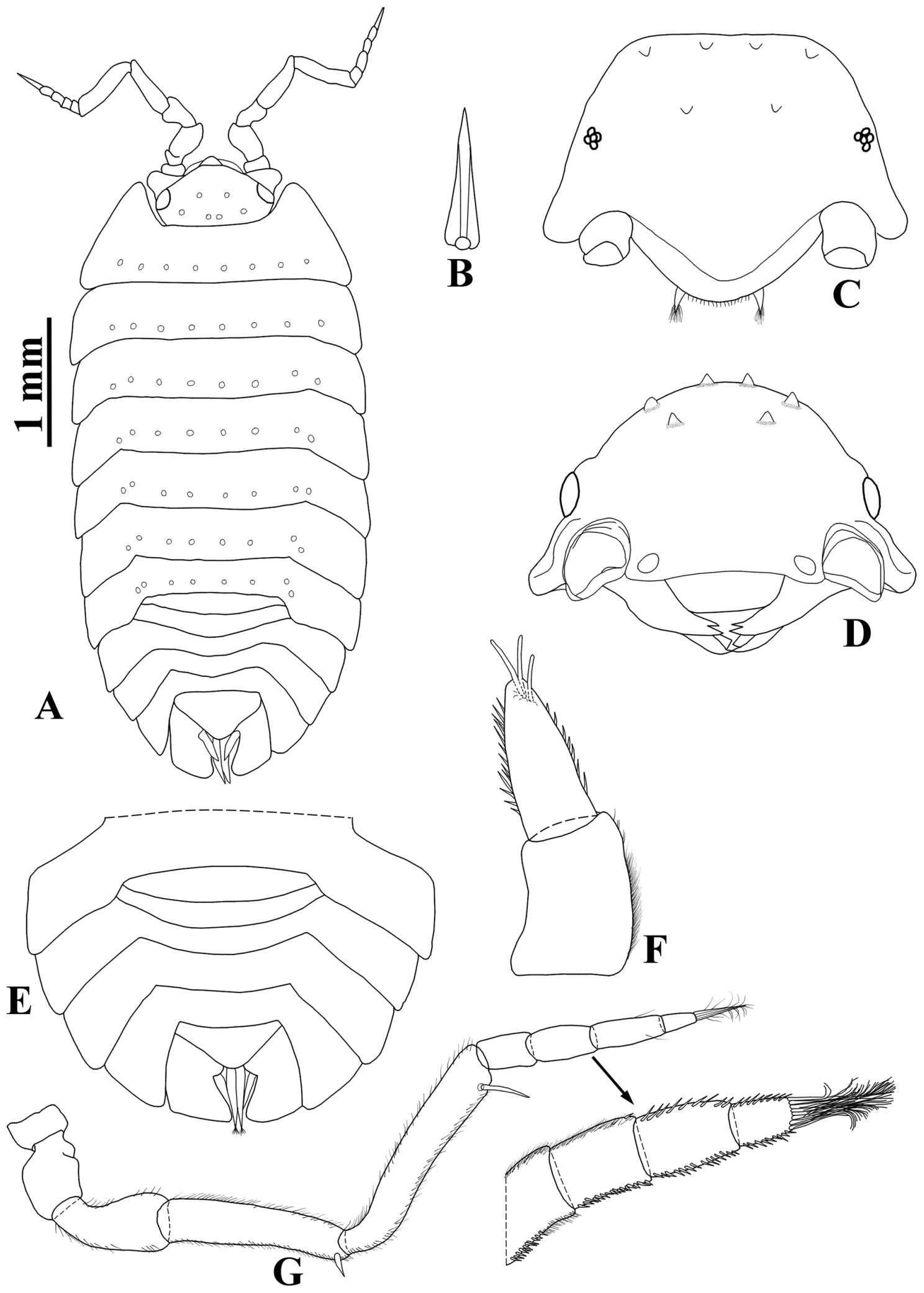

Fig. 13. Armadilloniscus ninae Schultz, 1984, $q$ (CDUC-CRU 216). A. Habitus, dorsal view. B. Dorsal scale-seta. C. Cephalon, dorsal view. D. Cephalon, frontal view. E. Pleon, telson and uropods. F. Antennula. G. Antenna. 


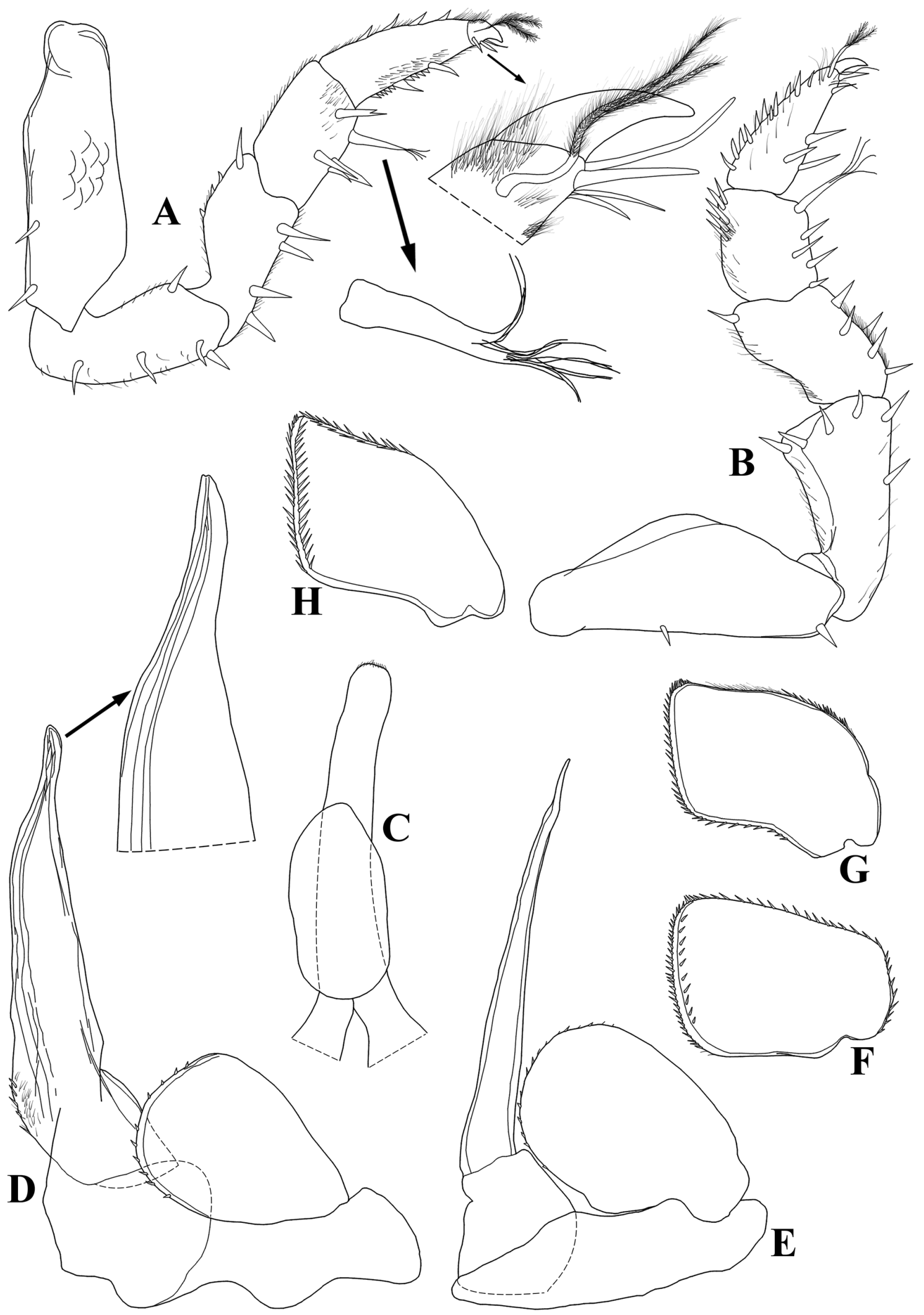

Fig. 14. Armadilloniscus ninae Schultz, 1984, ô (CDUC-CRU 216). A. Pereopod 1. B. Pereopod 7. C. Genital papilla. D. Pleopod 1. E. Pleopod 2. F. Pleopod 3 exopod. G. Pleopod 4 exopod. H. Pleopod 5 exopod. 
Genital papiLla. Ventral shield stout triangular, papilla rounded at apex, bearing small setae (Fig. 14C).

Pleopods. Pleopod 1 (Fig. 14D) exopod ovoid, wider than long; endopod stout, three times as long as exopod, apical portion slightly bent inwards. Pleopod 2 (Fig. 14E) exopod ovoid, wider than long; endopod with flagelliform distal article. Exopods of pleopods 3-5 as in Fig. 14F-H.

\section{Remarks}

Schultz (1984) described A. ninae from San Pedro beach, Ambergris Cay, Belize. Comparing Shultz's description with the specimens examined here, it was possible to observe that almost all characters mentioned, including the pale dorsal pigmentation, are quite similar. However, Schultz (1984) mentioned that $A$. ninae has eyes composed of 14 ommatidia and antennula with three articles, and herein the specimens showed the eyes composed of 5 ommatidia and antennula of two articles. Most probably, the author misinterpreted the composition of the eyes of this species, since the illustrations of the cephalon clearly show a smaller number. The same statement can be applied to the antennula. In general, within Oniscidea, the composition of the antennula does not vary within the genera, with just few exceptions (see Schmidt 2002, 2003). Moreover, analyzing other representatives of Armadilloniscus, it is possible to observe that the antennula is always composed of two articles (see Taiti \& Ferrara 1989; Kwon \& Wang 1996). Therefore, we identify our specimens as $A$. ninae.

\section{Distribution}

This species was previously recorded only from San Pedro beach, Ambergris Cay, Belize (Schultz 1984). First record for Colombia and Cuba.

Family Halophilosciidae Verhoeff, 1908

\section{Remarks}

The family Halophilosciidae comprises 34 species distributed in three genera, Halophiloscia Verhoeff, 1908 (9 spp.), Littorophiloscia Hatch, 1947 (22 spp.), and Stenophiloscia Verhoeff, 1908 (3 spp.)(WoRMS 2020c). In Colombia, Pearse (1915) recorded Philoscia culebrae Moore, 1901 [= Littorophiloscia c.] in coffee plantations from Hacienda Cincinati and Hacienda La Rosa, Sierra Nevada de Santa Marta (ca 1400 m a.s.l.), which is considered to be a misidentification by Van Name (1936). Littorophiloscia culebrae (Moore, 1901) is recorded from coastal areas of Angola, Brazil, Canary Islands, Caribbean islands, Florida (USA), Hawaii, Iraq, Madagascar, Socotra Archipelago and Yemen (Schmalfuss 2003; Taiti \& Ferrara 2004; Araujo \& Taiti 2007; Taiti \& Lopez 2008; Naser et al. 2015; Lisboa et al. 2017; Campos-Filho et al. 2018). Recent expeditions to the north coast of Bolívar revealed the existence of this species in Colombia, inhabiting the coastal areas of the Barú Peninsula, Cartagena de Indias (C. López-Orozco \& Y. Carpio-Díaz, pers. obs.).

Genus Halophiloscia Verhoeff, 1908

Microphiloscia Vandel, 1973. Syn. nov.

Halophiloscia trichoniscoides (Vandel, 1973) comb. nov.

Figs 1, 2G, 15-17

Microphiloscia trichoniscoides Vandel, 1973: 170, figs 19-21.

\section{Material examined}

COLOMBIA - Bolívar, Cartagena de Indias, Islas del Rosario, Isla Grande $\bullet 3 \hat{\partial} \widehat{\partial}$; Paraíso Secreto; $10^{\circ} 10^{\prime} 15.9^{\prime \prime}$ N, 7544'38.8" W; 4 Apr. 2018; C.M. López-Orozco, R. Borja-Arrieta and K. Meza leg.; CUDC-CRU 218, 220, 221 $11 \hat{\jmath}, 1$ ㅇ (parts in micropreparations); same locality as for preceding; 6 Sep. 2017; C.M. López-Orozco, Y.M. Carpio-Díaz and R. Borja-Arrieta leg.; CUDC-CRU 219. 
CUBA - Matanzas, Bahia de Conchinos 4 d $\hat{\partial}, 10$ 우; near Cueva de los Peces, between Playa

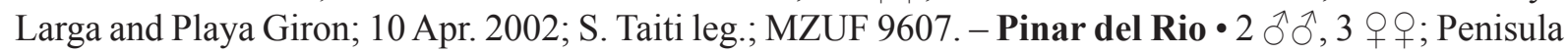
Guanahacabibes, La Bajada; 7 Apr. 2002; S. Taiti leg.; MZUF 9608.

\section{Redescription}

Measurements. Maximum body length: male $2.8 \mathrm{~mm}$ and female $4 \mathrm{~mm}$.

Body. Color light brown (Fig. 2G), mottled with the usual pale muscle spots; posterior margins of pereonites 4-7, pleonites 3-5 and uropod branches more pigmented. Body outline as in Fig. 15A. Back

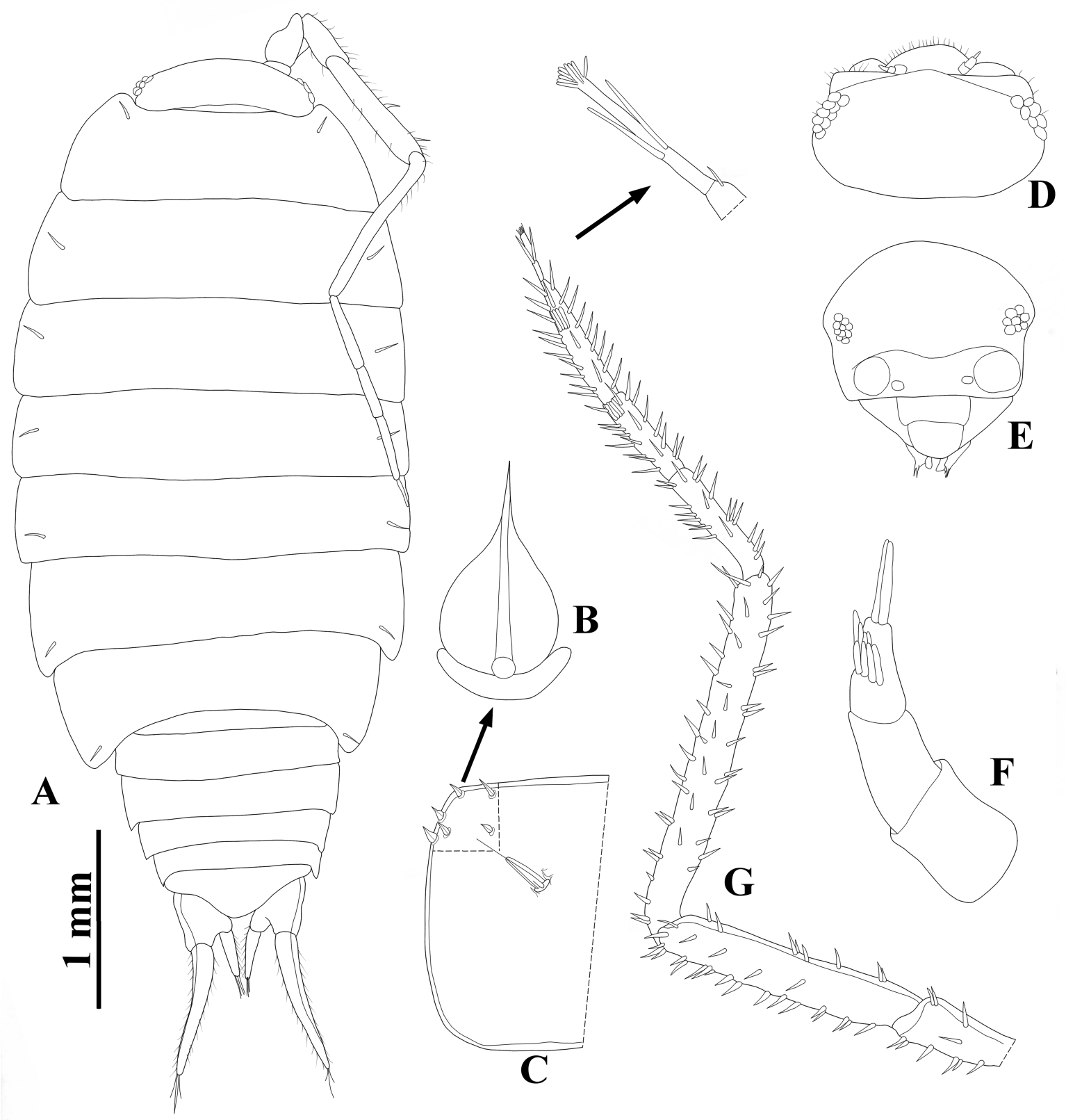

Fig. 15. Halophiloscia trichoniscoides (Vandel, 1973) comb. nov., $q$ (MZUF 9607). A. Habitus, dorsal view. B. Dorsal scale-seta. C. Epimera 4 with noduli laterales. D. Cephalon, dorsal view. E. Cephalon, frontal view. F. Antennula. G. Antenna. 
smooth with numerous triangular scale-setae (Fig. 15B). One line of noduli laterales per side on the pereonites inserted at same distance from lateral margins (Fig. 15A, C).

Cephalon. Without frontal line, suprantennal line straight on median portion; eyes consisting of 10 ommatidia (Fig. 15D-E).

Pleon. Narrower than pereon; epimera of pleonites 3-5 not developed. Telson with lateral sides slightly concave, distal margin broadly rounded (Fig. 15A).

Antennula. Composed of three articles subequal in length, distal article with two lateral aesthetascs plus apical pair (Fig. 15F).

ANTENNA. When extended posteriorly reaches posterior margin of pereonite 5; flagellum as long as fifth article of peduncle, first article slightly longer than second and third, second and third articles with three and two lateral aesthetascs, respectively (Fig. 15G).

Mouth. Mandibles with molar penicil consisting of at least five branches, left mandible with $2+1$ penicils (Fig. 16A), right mandible with $1+1$ penicils (Fig. 16B). Maxillula (Fig. 16C) inner endite with two long penicils inserted transversely; outer endite of $5+5$ teeth, inner set apically cleft. Maxilla (Fig. 16D) with

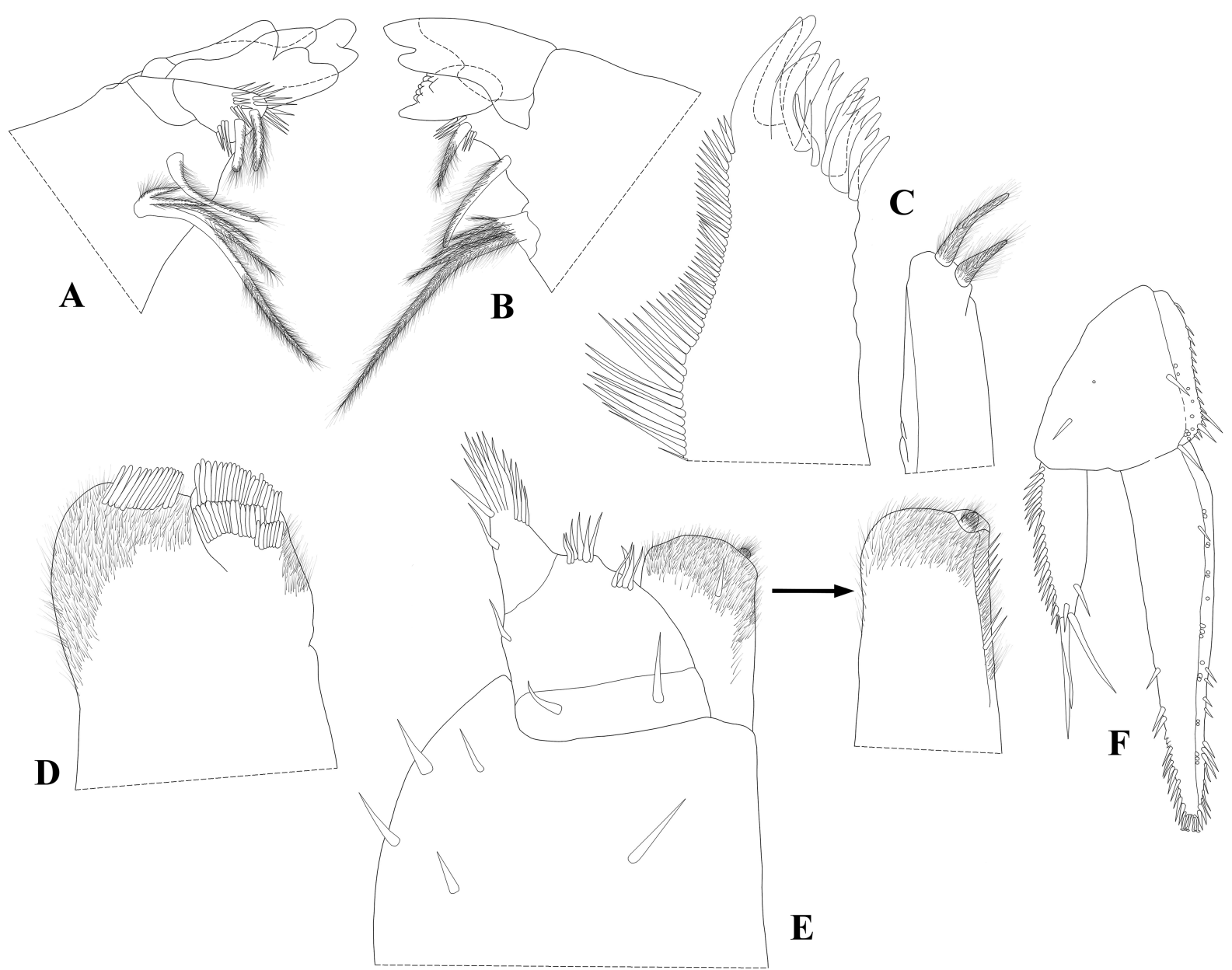

Fig. 16. Halophiloscia trichoniscoides (Vandel, 1973) comb. nov., $q$ (MZUF 9607). A. Left mandible. B. Right mandible. C. Maxillula. D. Maxilla. E. Maxilliped. F. Uropod. 
bilobate apex, inner lobe rounded, bearing thick setae, outer lobe rounded, covered with thin setae plus three thick setae. Maxilliped (Fig. 16E) base bearing sparse setae, proximal article of palp with two stout setae slightly distinct in length; endite subrectangular, inner and distal margins bearing several thin setae, medial seta not surpassing distal margin, distal margin with one small hairy penicil.

UROPOD. Protopod and exopod grooved on outer margin, bearing many glandular pores, exopod almost three times as long as endopod (Fig. 16F).

Pereopods. Rather slender, pereopod 1 carpus bearing transverse antennal grooming brush and distal seta apically cleft; dactylus with ungual seta simple and surpassing outer claw, dactylar seta simple, not surpassing outer claw.

\section{Male}

Pereopods 1 and 7. Pereopod 1 (Fig. 17A) propodus slightly flattened, carpus with transverse antennal grooming brush and distal seta hand-like. Pereopod 7 (Fig. 17B) without any sexual dimorphism.

GENITAL PAPILLA. Ventral shield ovoid, papilla bifurcate with genital orifices opening at apex (Fig. 17C).

Pleopods. Pleopod 1 (Fig. 17D) exopod triangular, inner margin almost straight, outer margin sinuous, distal portion triangular with distal margin rounded; endopod with thickest distal part with sides almost parallel, inner distal part with long pointed process concave on outer margin, prominent subquadrangular apical lobe on outer distal portion bearing thin setae. Pleopod 2 (Fig. 17E) exopod triangular, outer margin concave, bearing seven stout setae; endopod robust, distinctly longer than exopod. Exopods of pleopods $3-5$ as in Fig. 17F-H.

\section{Remarks}

Vandel (1973) erected the genus Microphiloscia to allocate the new species M. trichoniscoides from Cueva de la Colorada, Provincia de Oriente, Sierra Maestra, Colorada del Maso, Cuba. After the examination of material belonging to this species, $M$. trichoniscoides shows the shape of the genital papilla and male pleopod 1 endopod typical of members of Halophiloscia (see also Taiti \& Lopez 2008). Halophiloscia includes 9 halophilic species mainly distributed along the Mediterranean and Atlantic coasts of Europe and Africa (Schmalfuss 2003; Taiti \& Lopez 2008; Taiti \& Argano 2009, 2011). In America, only H. couchii (Kinahan, 1858) was recorded, from Argentina, Bermuda, and USA (see Schmidt 2003). The genus is mainly characterized by the runner-type habitus (sensu Schmalfuss 1984), epimera of pereonites 1-7 with one or more lines of noduli laterales, male pereopod 1 and sometimes pereopod 2 carpus and propodus enlarged and covered with several scales on frontal side, male genital papilla distally bifurcated, and male pleopod 1 endopod stout bearing a long, pointed process on the apex (see Schmidt 2003; Taiti \& Lopez 2008). The species is included within the genus since it shows all the previously mentioned characters, except that the male pereopods 1 and 2 do not have the carpus and propodus enlarged. Thus, Microphiloscia is considered to be a junior synonym of Halophiloscia.

\section{Distribution}

Cuba (Vandel 1973). First record for Colombia. 


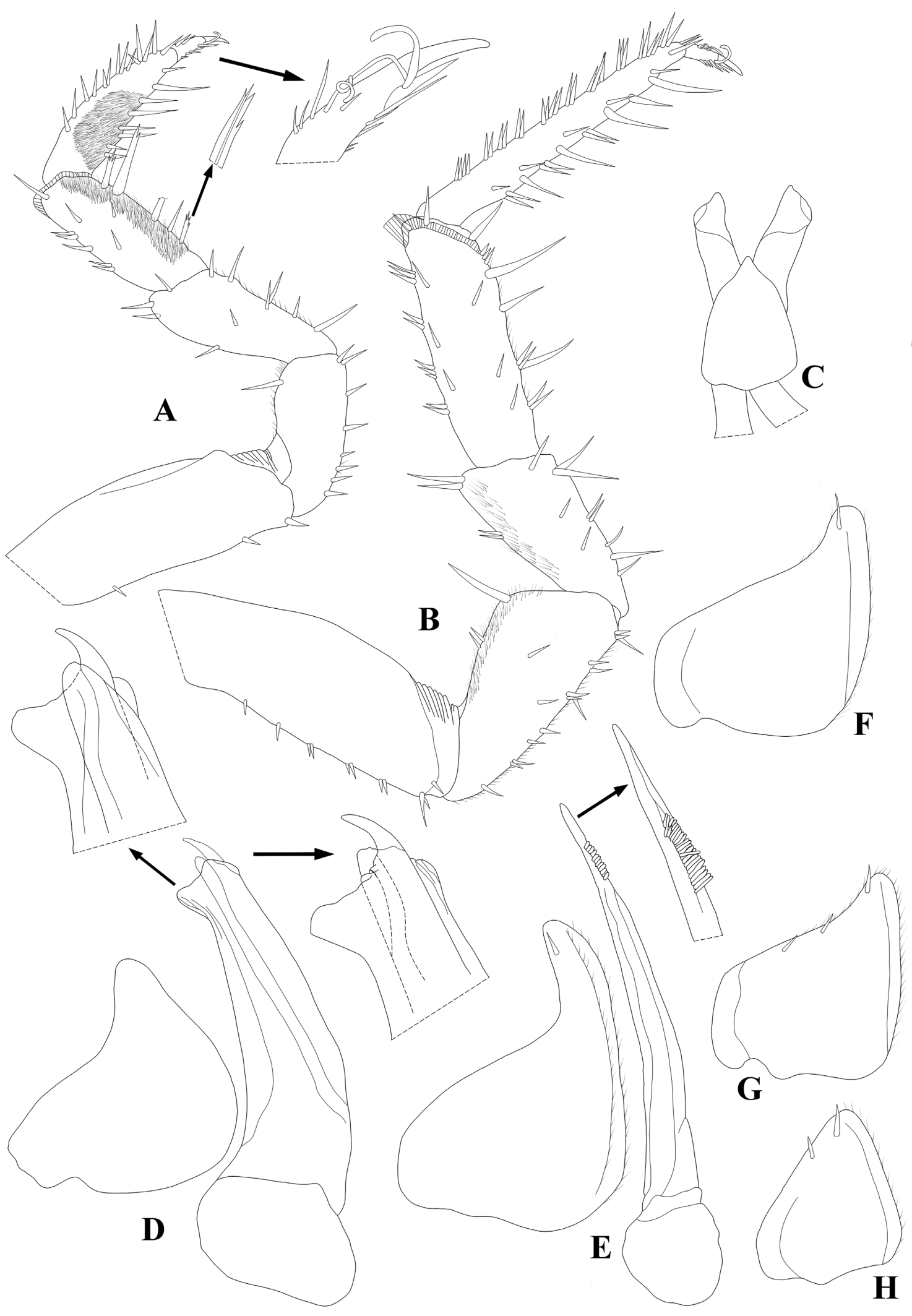

Fig. 17. Halophiloscia trichoniscoides (Vandel, 1973) comb. nov., đ̊ (MZUF 9607). A. Pereopod 1. B. Pereopod 7. C. Genital papilla. D. Pleopod 1. E. Pleopod 2. F. Pleopod 3 exopod. G. Pleopod 4 exopod. H. Pleopod 5 exopod. 
Genus Littorophiloscia Hatch, 1947

Littorophiloscia amphindica Taiti \& Ferrara, 1986

Figs 1,2H

Littorophiloscia amphindica Taiti \& Ferrara, 1986: 1369, fig. 16.

\section{Material examined}

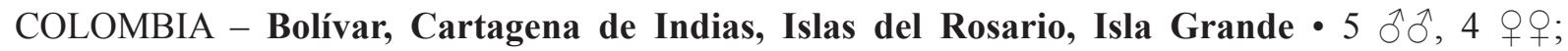
El Silencio, Laguna Caracolí; 10¹0'28.4" N, 7544'29.96" W; 6 Oct. 2017; Y.M. Carpio-Díaz and R. Borja-Arrieta leg.; CUDC-CRU 223 • 1 ô, 1 क; El Silencio, Laguna del Silencio; 10¹0'34" N, 7544'26.8” W; 25 Aug. 2017; leg. Y.M. Carpio-Díaz, C.M. López-Orozco and R. Borja-Arrieta; CUDC-

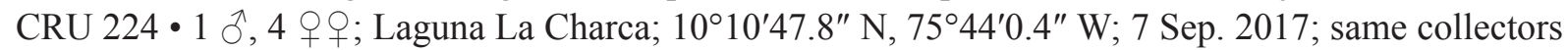

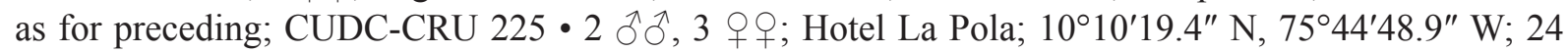

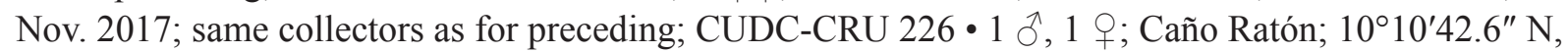

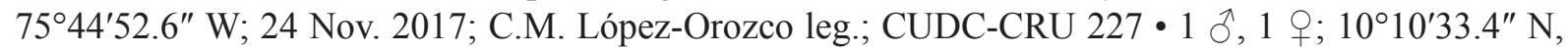
7544'52.4" W; 24 Nov. 2017; C.M. López-Orozco, Y.M. Carpio-Díaz and R. Borja-Arrieta leg.; CUDCCRU 228 • 1 万’, 3 우; same collection data as for preceding; $10^{\circ} 10^{\prime} 44.91^{\prime \prime} \mathrm{N}, 75^{\circ} 44^{\prime} 53.01^{\prime \prime} \mathrm{W}$; CUDC-

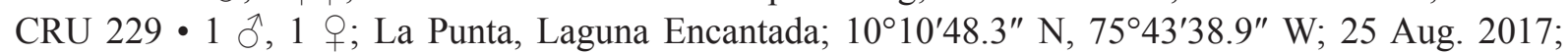

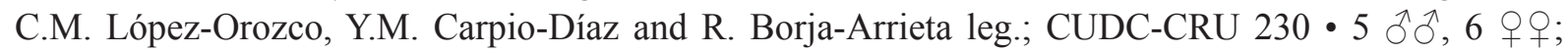
same collection data as for preceding; $10^{\circ} 10^{\prime} 48.1^{\prime \prime} \mathrm{N}, 7^{\circ} 43^{\prime} 39.1^{\prime \prime} \mathrm{W}$; CUDC-CRU 231 • 9 우 ; same collection data as for preceding; $10^{\circ} 10^{\prime} 48.1^{\prime \prime} \mathrm{N}, 75^{\circ} 43^{\prime} 37.5^{\prime \prime} \mathrm{W}$; CUDC-CRU $232 \bullet 1$ \% ; same collection data as for preceding; $10^{\circ} 10^{\prime} 48.4^{\prime \prime} \mathrm{N}, 75^{\circ} 43^{\prime} 38.4^{\prime \prime} \mathrm{W}$; CUDC-CRU $233 \cdot 1$ क ; same collection data as for preceding; $10^{\circ} 10^{\prime} 48^{\prime \prime} \mathrm{N}, 75^{\circ} 43^{\prime} 39.3^{\prime \prime} \mathrm{W}$; CUDC-CRU 234 • 1 ㅇ, 5 우우 ; same collection data as for

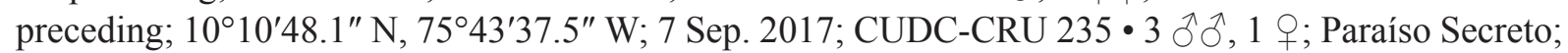

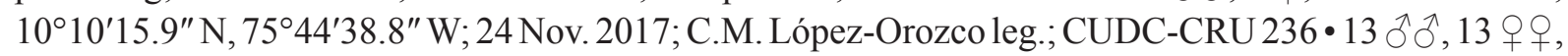
8 juvs; same locality and collector as for preceding, 6 Sep. 2017; CUDC-CRU $237 \cdot 14$ ठิ $\widehat{\jmath}, 32$ 우, 3 juvs; same locality as for preceding; 4 Apr. 2018; C.M. López-Orozco, R. Borja-Arrieta and K. Meza leg.; CUDC-CRU 238.

\section{Distribution}

Tanzania (Zanzíbar), Maldives, Comoro Islands, Indonesia (Bali) and Taiwan (Schmalfuss 2003; Taiti 2014). First record for Colombia.

Littorophiloscia denticulata (Ferrara \& Taiti, 1982)

Figs 1, 2I

Bilawrencia denticulata Ferrara \& Taiti, 1982: 469, figs 6-7.

\section{Additional reference}

Leistikow (2000).

\section{Material examined}

COLOMBIA - Bolívar, Cartagena de Indias, Islas del Rosario, Isla Grande • 1 $\widehat{\partial}, 2$ $q$; ; El Silencio, Laguna Caracolí; 10¹0'28.4" N, 7544'29.96"' W; 6 Oct. 2017; Y.M. Carpio-Díaz and R. Borja-

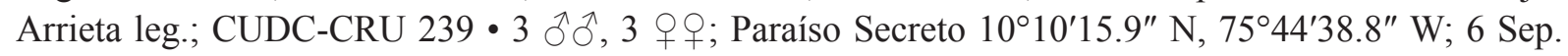

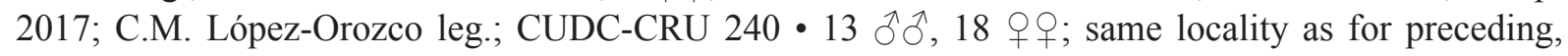
4 Apr. 2018; C.M. López-Orozco, R. Borja-Arrieta and K. Meza leg.; CUDC-CRU 241. 


\section{Distribution}

Andaman Islands, Brazil and Guatemala (Schmalfuss 2003; Lisboa et al. 2017). First record for Colombia.

Littorophiloscia tropicalis Taiti \& Ferrara, 1986

Figs 1, 2J

Littorophiloscia tropicalis Taiti \& Ferrara, 1986: 1361, fig. 9.

\section{Material examined}

COLOMBIA - Bolívar, Cartagena de Indias, Islas del Rosario, Isla Grande $\bullet$ many $\hat{\partial} \widehat{\partial}$ and $\phi \circ$; Playa Libre; $10^{\circ} 10^{\prime} 52.3^{\prime \prime}$ N, 7543'55.7" W; 7 Sep. 2017; C.M. López-Orozco, R. Borja-Arrieta and Y.M. Carpio-Díaz leg.; CUDC-CRU 242 • 1 ^ , 6 우; same locality as for preceding; $10^{\circ} 10^{\prime} 52.3^{\prime \prime} \mathrm{N}$,

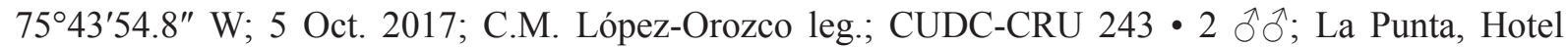
Majagua; $10^{\circ} 10^{\prime} 56.41^{\prime \prime} \mathrm{N}, 75^{\circ} 43^{\prime} 33.51^{\prime \prime} \mathrm{W}$; 6 Oct. 2017; C.M. López-Orozco and L. Vides leg.; CUDC-

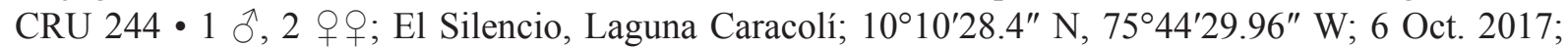
Y.M. Carpio-Díaz and R. Borja-Arrieta leg.; CUDC-CRU 245 • 1 ô, 2 우, 1 juv.; El Silencio, Playa La Cocotera; $10^{\circ} 10^{\prime} 49.3^{\prime \prime}$ N, 7544'16.7" W; 6 Oct. 2017; C.M. López-Orozco leg.; CUDC-CRU 246 • 1 ठૈ, 2 오; Caño Ratón; $10^{\circ} 10^{\prime} 44.91^{\prime \prime}$ N, 7544'53.01" W; 24 Nov. 2017; C.M. López-Orozco, R. BorjaArrieta and Y.M. Carpio-Díaz leg.; CUDC-CRU $247 \bullet 2$ ๙ิ $\widehat{0}, 2$ 우; same locality, date and collectors; as for preceding; $10^{\circ} 10^{\prime} 33.4^{\prime \prime} \mathrm{N}, 75^{\circ} 44^{\prime} 52.4^{\prime \prime} \mathrm{W}$; CUDC-CRU $248 \cdot 1$ ô, 3 ㅇ; Paraíso Secreto; $10^{\circ} 10^{\prime} 15.9^{\prime \prime} \mathrm{N}, 75^{\circ} 44^{\prime} 38.8^{\prime \prime} \mathrm{W}$; 24 Nov. 2017; C.M. López-Orozco leg.; ICN-CR-is 265.

\section{Distribution}

Circumtropical (Schmalfuss 2003; Taiti \& Ferrara 2004; Taiti \& Checcucci 2009; Taiti 2014; Lisboa et al. 2017). First record for Colombia.

Family Platyarthridae Verhoeff, 1949

Genus Trichorhina Budde-Lund, 1908

Trichorhina bermudezae Carpio-Díaz, López-Orozco \& Campos-Filho, 2018

Fig. 1

Trichorhina bermudezae Carpio-Díaz, López-Orozco \& Campos-Filho in Carpio-Díaz et al., 2018: 307, figs 29-50.

\section{Material examined}

COLOMBIA - Bolívar, Cartagena de Indias, Islas del Rosario, Isla Grande • 1 đ; La Punta (TDF); $10^{\circ} 10^{\prime} 48.42^{\prime \prime}$ N, 7543'41.36" W; 8 Sep. 2017; Y.M. Carpio-Díaz, C.M. López-Orozco and R. BorjaArrieta leg.; CUDC-CRU $267 \cdot 1$ đo, 1 q; same collection data as for preceding; $10^{\circ} 10^{\prime} 47.36^{\prime \prime} \mathrm{N}$,

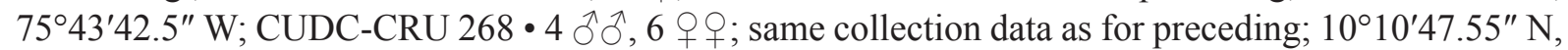
$75^{\circ} 43^{\prime} 42.09^{\prime \prime} \mathrm{W}$; CUDC-CRU 269 $2 \mathrm{o}^{\wedge} \mathrm{o}^{\wedge}, 7$ $q$ \% ; same collection data as for preceding; $10^{\circ} 10^{\prime} 46.79^{\prime \prime} \mathrm{N}$, $75^{\circ} 43^{\prime} 43.51^{\prime \prime} \mathrm{W}$; CUDC-CRU 270 • 2 ๙ิ $\mathrm{o}^{\circ}, 6$ 우우; same collection data as for preceding; $10^{\circ} 10^{\prime} 48.02^{\prime \prime} \mathrm{N}$,

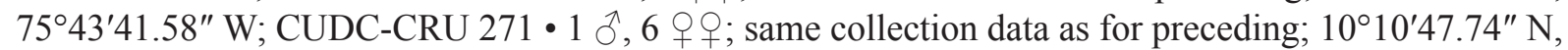
$75^{\circ} 43^{\prime} 41.8^{\prime \prime} \mathrm{W}$; CUDC-CRU 272 • 1 今, 6 우 웅 same collection data as for preceding; $10^{\circ} 10^{\prime} 48.1^{\prime \prime} \mathrm{N}$,

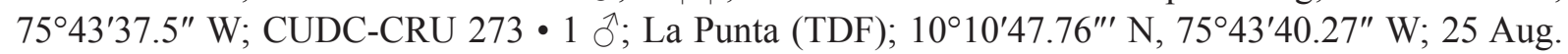
2017; Y.M. Carpio-Díaz, C.M. López-Orozco and R. Borja-Arrieta leg.; CUDC-CRU 274 • 1 đ, 1 O ; La Punta, Casa Sra. Miriam; 10¹0'46.91" N, 7543'46.73" W; 8 Sep. 2017; C.M. López-Orozco, R. 
Borja-Arrieta and Y.M. Carpio-Díaz leg.; CUDC-CRU 275 • 2 우; El Silencio, Laguna Caracolí; $10^{\circ} 10^{\prime} 28.4^{\prime \prime}$ N, 7544'29.96" W; 6 Oct. 2017; Y.M. Carpio-Díaz and R. Borja-Arrieta leg.; CUDC-

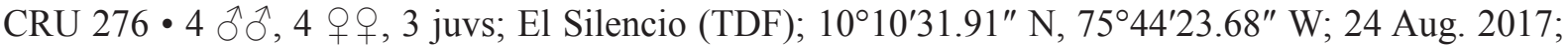
A. Figueroa and B. Valencia leg.; CUDC-CRU 277 - 1 त, 1 क; El Silencio, Laguna del Silencio;

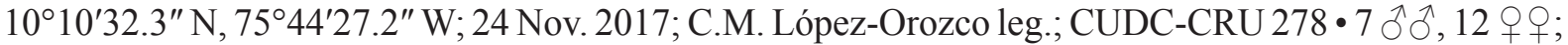
El Paraiso (TDF); 10¹0'22.9" N, 7544'32.8" W; 6 Sep. 2017; C.M. López-Orozco, R. Borja-Arrieta and Y.M. Carpio-Díaz leg.; CUDC-CRU 279 • 3 ô ô; Caño Ratón; $10^{\circ} 10^{\prime} 42.9^{\prime \prime}$ N, 7544'52.8" W; 24 Nov. 2017; C.M. López-Orozco leg.; CUDC-CRU 280.

\section{Previous records}

Botanical Garden “Guillermo Piñeres”, Turbaco, Bolívar (Carpio-Díaz et al. 2018).

\section{Distribution}

Colombia. First record for continental islands of the Colombian Caribbean.

Trichorhina heterophthalma Lemos de Castro, 1964

Fig. 1

Trichorhina heterophthalma Lemos de Castro, 1964: 2, figs 1-2.

Trichorhina heterophthalma - Carpio-Díaz et al. 2018: 303, fig. 3.

\section{Material examined}

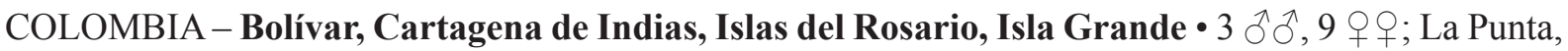
Casa Sra. Miriam; $10^{\circ} 10^{\prime} 46.91^{\prime \prime}$ N, 7543'46.73" W; 8 Sep. 2017; C.M. López-Orozco, R. Borja-Arrieta and Y.M. Carpio-Díaz leg.; CUDC-CRU 260 • 3 o o+; Caño Ratón; $10^{\circ} 10^{\prime} 42.9^{\prime \prime}$ N, 75²4'52.8" W; 24 Nov. 2017; C.M. López-Orozco leg.; CUDC-CRU 261 • 3 q o+; El Silencio, Laguna del Silencio; $10^{\circ} 10^{\prime} 31.91^{\prime \prime} \mathrm{N}, 75^{\circ} 44^{\prime 2} 3.68^{\prime \prime} \mathrm{W} ; 25$ Aug. 2017; Alison Figueroa leg.; CUDC-CRU 262・ 1 §, 1 ㅇ; La

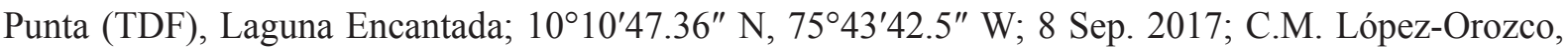
Y.M. Carpio-Díaz and R. Borja-Arrieta leg.; CUDC-CRU 263 • 2 § $\widehat{\jmath}, 3$ juvs; same locality, date and collectors as for preceding; $10^{\circ} 10^{\prime} 47.55^{\prime \prime} \mathrm{N}, 75^{\circ} 43^{\prime} 42.89^{\prime \prime} \mathrm{W}$; CUDC-CRU $264 \bullet 2$ 우; same locality

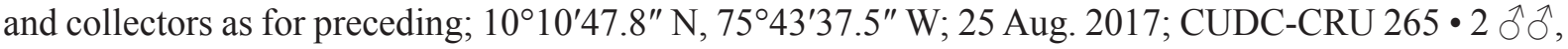
2 우우 a Punta; $10^{\circ} 10^{\prime} 47.74^{\prime \prime} \mathrm{N}, 7^{\circ} 43^{\prime} 41.85^{\prime \prime} \mathrm{W} ; 8$ Sep. 2017, same collectors as for preceding; CUDC-CRU 266.

\section{Previous records}

Botanical Garden “Guillermo Piñeres”, Turbaco, Bolívar (Carpio-Díaz et al. 2018).

\section{Distribution}

Pantropical (Schmalfuss 2003). First record for continental islands of the Colombian Caribbean.

Family Porcellionidae Brandt, 1831

Genus Porcellionides Miers, 1877

Porcellionides pruinosus (Brandt, 1833)

Fig. 1

Porcellio pruinosus Brandt, 1833: 19. 
Porcellionides pruinosus - Carpio-Díaz et al. 2016: 434, figs 1-2.

\section{Material examined}

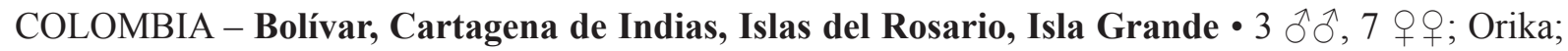

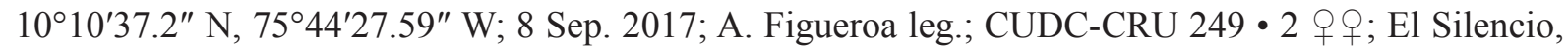
Playa La Cocotera; $10^{\circ} 10^{\prime} 49.3^{\prime \prime} \mathrm{N}, 7^{\circ} 44^{\prime} 16.7^{\prime \prime} \mathrm{W}$; 6 Oct. 2017; C.M. López-Orozco, R. Borja-Arrieta and

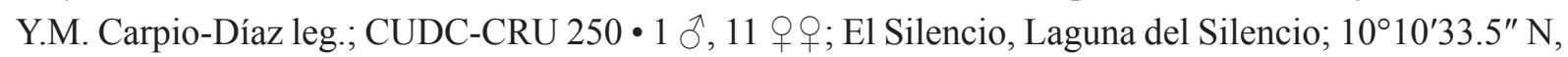
7544'26.9" W; 24 Aug. 2017, same collectors as for preceding; CUDC-CRU 251 • 1 क; same collection data as for preceding; $10^{\circ} 10^{\prime} 32.9^{\prime \prime} \mathrm{N}, 75^{\circ} 44^{\prime} 27.3^{\prime \prime} \mathrm{W}$; CUDC-CRU $252 \cdot 18 \hat{\jmath} \partial^{\circ}, 15$ 우, 1 juvenile; same collection data as for preceding; $10^{\circ} 10^{\prime} 35^{\prime \prime} \mathrm{N}, 75^{\circ} 44^{\prime} 26.4^{\prime \prime} \mathrm{W}$; CUDC-CRU $253 \cdot 3$ q \% ; La Punta, Laguna Encantada; 10¹0'47.76" N, 7543'40.27" W; 25 Aug. 2017; C.M. López-Orozco, Y.M. CarpioDíaz and R. Borja-Arrieta leg.; CUDC-CRU 254.

\section{Previous records}

San Andrés (Van Name 1936); Angelópolis, Cafetal La Camelia Antioquia Dept, and near Nevado del Ruíz, Caldas Dept (Richardson 1912); Cartagena de Indias, Barú, Bolívar Dept (Caribbean region) (Carpio-Díaz et al. 2016).

\section{Distribution}

Cosmopolitan species (Schmalfuss 2003). First record for continental islands of the Colombian Caribbean.

Family Agnaridae Schmidt, 2003

Genus Agnara Budde-Lund, 1908

Agnara madagascariensis (Budde-Lund, 1885)

Figs 1, 2K

Metoponorthus Madagascariensis Budde-Lund, 1885: 189.

\section{Additional references}

Schmalfuss \& Ferrara (1978); Ferrara \& Taiti (1986).

\section{Material examined}

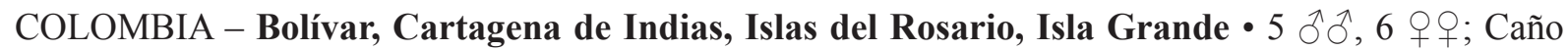
Ratón, Casa Comunal; 10¹0'39.06" N, 7544'50.4" W; 8 Sep. 2017; C.M. López-Orozco, R. Borja-

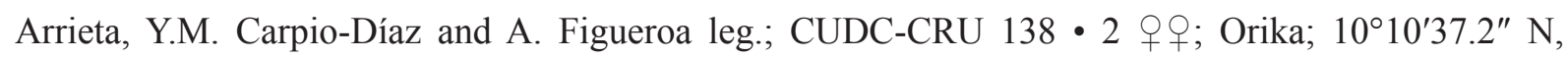

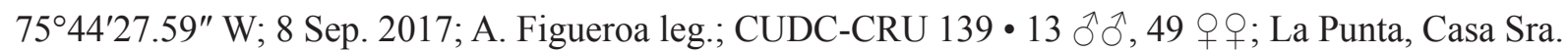
Miriam; $10^{\circ} 10^{\prime} 46.91^{\prime \prime}$ N, 7543'46.73" W; 8 Sep. 2017; C.M. López-Orozco, R. Borja-Arrieta and Y.M. Carpio-Díaz leg.; CUDC-CRU 140.

\section{Distribution}

Ascension Island, Senegal, Guinea Bissau, Arabian Peninsula, Madagascar, southern China, Taiwan and Venezuela (Ashmole \& Ashmole 2000; Schmidt 2001; Schmalfuss 2003). First record for Colombia. 
Family Armadillidae Brandt, 1831

Genus Ctenorillo Verhoeff, 1942

Ctenorillo tuberosus (Budde-Lund, 1904)

Figs 1, 2L

Armadillo tuberosus Budde-Lund, 1904: 109, pl. x, figs 1-4.

\section{Additional reference}

Campos-Filho et al. (2017).

\section{Material examined}

COLOMBIA - Bolívar, Cartagena de Indias, Islas del Rosario, Isla Grande • 1 đ̊; Caño Ratón, Casa Comunal; 10¹0'39.06" N, 7544'50.4" W; 8 Sep. 2017; C.M. López-Orozco, R. Borja-Arrieta,

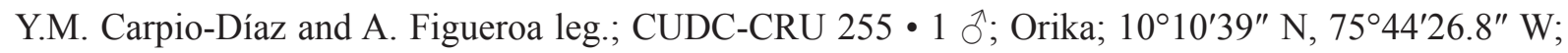

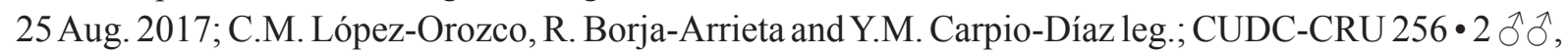
5 우; La Punta, Casa Sra. Miriam; $10^{\circ} 10^{\prime} 46.91^{\prime \prime}$ N, $75^{\circ} 43^{\prime} 46.73^{\prime \prime}$ W; 8 Sep. 2017; same collectors as for

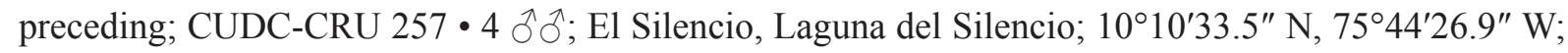
24 Aug. 2017, same collectors as for preceding; CUDC-CRU $258 \cdot 2$ o $\sigma^{\lambda}$; same collection data as for

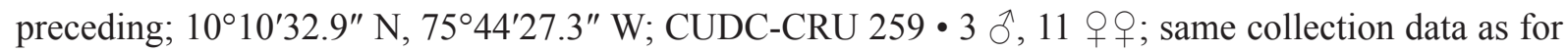
preceding; $10^{\circ} 10^{\prime} 34.3^{\prime \prime} \mathrm{N}, 75^{\circ} 44^{\prime} 26.7^{\prime \prime} \mathrm{W}$; ICN-CR-is 266.

\section{Distribution}

Brazil and Haiti (Schmalfuss 2003; Campos-Filho et al. 2017). First record for Colombia.

\section{Molecular phylogenetic analyses of Tylos Audouin, 1826}

Sequences obtained for the three species of Tylos from Isla Grande and the specimen from Florida have been deposited under GenBank Accession Numbers MW532964-MW532970 and MW533069MW533075. Only the 12S rDNA sequence was obtained for the specimen from Isla Grande assigned to T. marcuzzii. Phylogenetic analyses using only $12 \mathrm{~S}$ rDNA group this sequence with the two specimens of T. marcuzzii from Cuba reported in Hurtado et al. (2014); see Fig. 18. The 12S rDNA p-distance between T. marcuzzii from Isla Grande and T. marcuzzii from Cuba is 2.0-2.7\%, whereas the distance between the specimens from the two Cuban localities is $2.0 \%$ (Table 2). Only the $16 \mathrm{~S}$ rDNA sequence was obtained for the specimen of T. niveus from the Florida Keys, the type locality of this species. Phylogenetic analyses of $16 \mathrm{~S}$ rDNA show that specimens identified as T. niveus from Isla Grande are most closely related to the T. niveus specimen from the Florida Keys. The 16S rDNA p-distance between T. niveus from Isla Grande and the Florida Keys is $2.7 \%$ (Table 2).

The concatenated (12S rDNA and 16S rDNA) dataset was comprised of 43 taxa and 740 characters (excluding characters with ambiguous homology), 236 of which were parsimony-informative. The specimens assigned to T. marcuzzii were used as outgroup. Five main lineages were identified for the ingroup taxa in the concatenated phylogenetic analyses, which formed a basal polytomy (Fig. 18): (1) T. niveus from Puerto Rico; (2) Tylos sp. from Yaguanabo, Cuba; (3) T. niveus from Florida and Isla Grande; (4) T. negroi sp. nov.; and (5) Tylos punctatus sensu lato from the Northeastern Pacific. The range of $16 \mathrm{~S}$ rDNA and $12 \mathrm{~S}$ rDNA p-distances between the four basal lineages excluding T. punctatus is $11.1-13.6 \%$ and $9.7-15.5 \%$, respectively. The range of $16 \mathrm{~S}$ rDNA and $12 \mathrm{~S}$ rDNA p-distances between these ingroup lineages and T. marcuzzii is $19.4-22.2 \%$ and $19.5-23.8 \%$, respectively. 
Table 2. Genetic $p$-distance for 16S rDNA (above the diagonal) and 12S rDNA (below the diagonal) between the main genetic lineages of Tylos Audouin, 1826 in the Caribbean and Atlantic.

\begin{tabular}{|c|c|c|c|c|c|c|c|}
\hline & $\begin{array}{l}\text { T. niveus } \\
\text { Puerto Rico }\end{array}$ & $\begin{array}{l}\text { Tylos sp. } \\
\text { Yaguanabo, } \\
\text { Cuba }\end{array}$ & $\begin{array}{l}\text { T. negroi } \\
\text { sp. nov. Isla } \\
\text { Grande }\end{array}$ & $\begin{array}{l}\text { T. niveus } \\
\text { Isla Grande }\end{array}$ & $\begin{array}{c}\text { T. niveus } \\
\text { Florida Keys }\end{array}$ & $\begin{array}{l}\text { T. marcuzzii } \\
\text { Cayo Coco, } \\
\text { Cuba }\end{array}$ & $\begin{array}{c}\text { T. marcuzzii } \\
\text { Pinar del Rio, } \\
\text { Cuba }\end{array}$ \\
\hline T. niveus Puerto Rico & - & $12.3 \%$ & $11.1 \%$ & $9.7 \%$ & $11.4 \%$ & $19.4 \%$ & $19.9 \%$ \\
\hline Tylos sp. Yaguanabo, Cuba & $9.7 \%$ & - & $12.1 \%$ & $13.5 \%$ & $13.6 \%$ & $21.7 \%$ & $22.2 \%$ \\
\hline T. negroi sp. nov. Isla Grande & $10.9 \%$ & $14.7 \%$ & - & $12.4 \%$ & $12.5 \%$ & $21.1 \%$ & $21.4 \%$ \\
\hline T. niveus Isla Grande & $12.2 \%$ & $12.8 \%$ & $15.5 \%$ & - & $2.7 \%$ & $21.7 \%$ & $21.7 \%$ \\
\hline T. niveus Florida Keys & & & & & - & & \\
\hline T. marcuzzii Cayo Coco, Cuba & $21.0 \%$ & $20.0 \%$ & $21.9 \%$ & $20.4 \%$ & NA & - & $2.0 \%$ \\
\hline T. marcuzzii Pinar del Rio, Cuba & $20.6 \%$ & $19.7 \%$ & $22.1 \%$ & $20.4 \%$ & NA & $2.0 \%$ & - \\
\hline T. marcuzzii Isla Grande & $20.6 \%$ & $19.5 \%$ & $23.8 \%$ & $22.0 \%$ & NA & $2.0 \%$ & $2.7 \%$ \\
\hline
\end{tabular}

$\frac{\text { posterior probability }}{\text { SH-aLRT / bootstrap }}$

specimens from Isla Grande

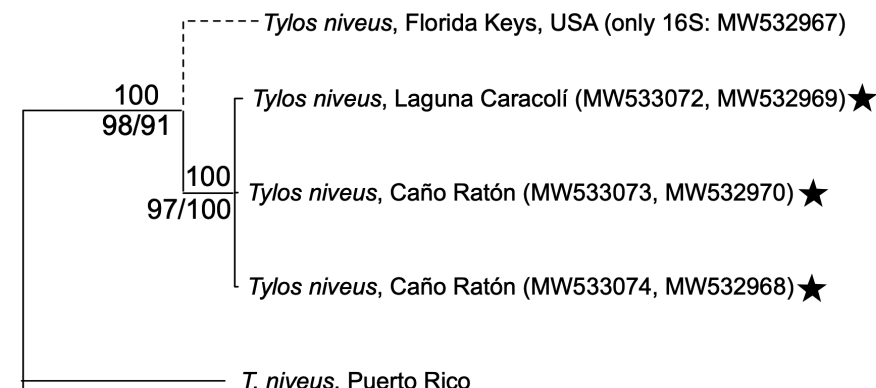

niveus, Puerto Rico

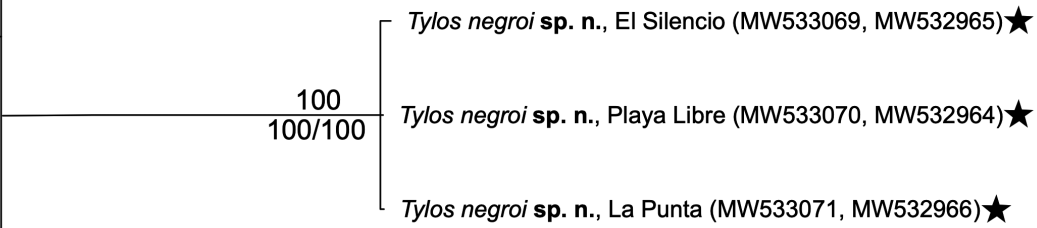

Tylos sp. Yaguanabo, Cuba

Tylos punctatus sensu lato Northeastern Pacific

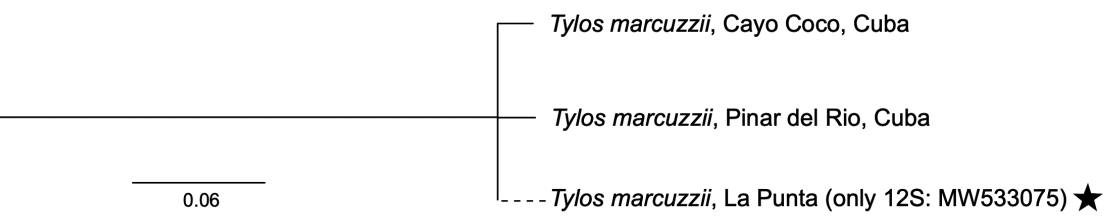

Fig. 18. Phylogenetic relationships among lineages of Tylos Audouin, 1826 from Isla Grande and their closest relatives. Majority rule consensus tree of the Bayesian posterior distribution (GTR+G+I model; 2 runs; 4 million generations; sampled every 1000; 10\% burn-in), based on the dataset combining the 12S rDNA and 16S rDNA genes (Supplementary file 3). Nodes with less than 70\% support (posterior probability, bootstrap, and SH-aLRT) for any dataset have been collapsed. Dashed lines represent relationships redrawn based on single gene analyses (Supplementary file 1 and Supplementary file 2). The split between the outgroup (T. marcuzzii) and the ingroup received 100\% support in all analyses. Specimens from Isla Grande, Colombia are marked with a star. GenBank accession numbers for newly generated sequences are provided in parentheses. 


\section{Key to species of terrestrial isopods from Isla Grande}

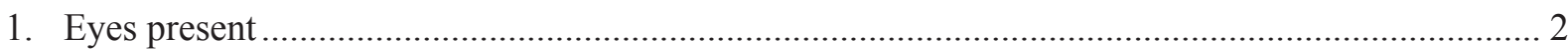

- Eyes absent ................................ Stenoniscus nestori López-Orozco, Taiti \& Campos-Filho sp. nov.

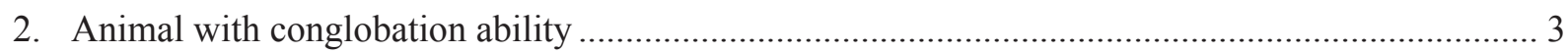

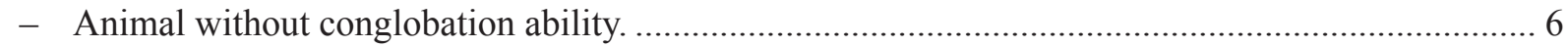

3. Pereon dorsally smooth; pereonite 5 epimera with ventral phylacomera....................................... 4

- Pereon dorsally tuberculate; pereonite 5 epimera without phylacomera

Ctenorillo tuberosus (Budde-Lund, 1904)

4. Phylacomera 5 paddle-shaped, extended anteriorly

- Phylacomera 5 sickle-shaped. Tylos marcuzzii Giordani Soika, 1954

5. Inner lobe of schisma extending beyond posterior margin of outer lobe

.Tylos negroi López-Orozco, Carpio-Díaz \& Campos-Filho sp. nov.

- Inner lobe of schisma not extending beyond posterior margin of outer lobe

Tylos niveus Budde-Lund, 1885

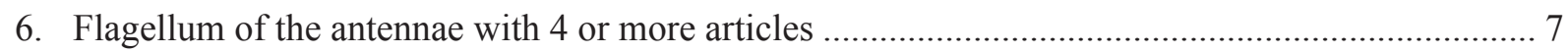

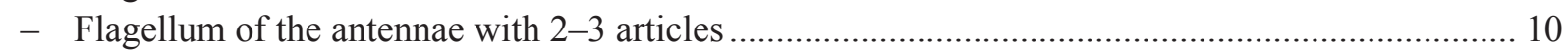

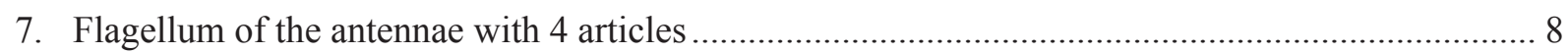

- Flagellum of the antennae with more than 10 articles..........Ligia baudiniana Milne-Edwards, 1840

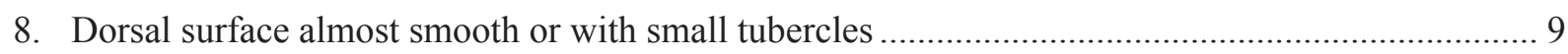

- Dorsal surface of pereon with 4 prominent longitudinal ribs

Armadilloniscus caraibicus Paoletti \& Stinner, 1989

9. Dorsal surface almost smooth. Armadilloniscus ninae Schultz, 1984

- Dorsal surface with small tubercles Armadilloniscus luisi Carpio-Díaz, Taiti \& Campos-Filho sp. nov.

10. Flagellum of the antennae with 3 articles 11

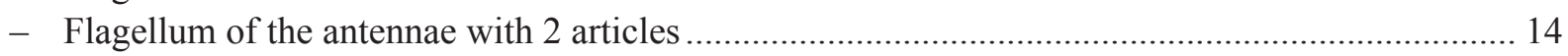

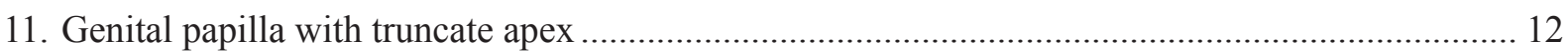

- Genital papilla with bifurcated apex....... Halophiloscia trichoniscoides (Vandel, 1973) comb. nov.

12. Male pleopod 1 endopod without lobe on outer margin of apical part

- Male pleopod 1 endopod with a lobe on outer margin of apical part.

Littorophiloscia tropicalis Taiti \& Ferrara, 1986

13. Male pleopod 1 endopod with apex divided into three points

Littorophiloscia amphindica Taiti \& Ferrara, 1986

- Male pleopod 1 endopod with a long spine and 2 small distinct denticles on the inner margin of the apical part.

Littorophiloscia denticulata (Ferrara \& Taiti, 1982)

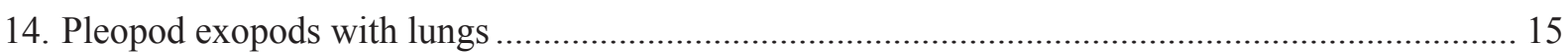

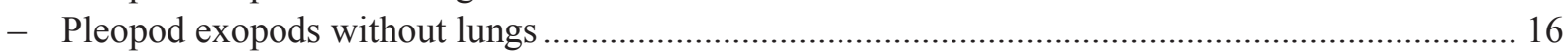


15. Pleopodal lungs present in first two pairs of pleopods ...... Porcellionides pruinosus (Brandt, 1833)

- Pleopodal lungs present in all five pairs of pleopods

Agnara madagascariensis (Budde-Lund, 1885)

16. Colorless body; eyes composed of two unequal ommatidia.

Trichorhina heterophthalma Lemos de Castro, 1964

- Pigmented body; eyes with 10 ommatidia

Trichorhina bermudezae Carpio-Díaz, López-Orozco \& Campos-Filho, 2018

\section{Discussion}

Despite its small area, Isla Grande appears to harbor a high diversity of oniscideans in coastal habitats (i.e., from beaches, coastal lagoons and mangroves), where 16 of the 17 species reported here were observed (Table 1). These include species commonly found in the Caribbean region (Ligia baudiniana, Tylos niveus, T. marcuzzii, Armadilloniscus caraibicus, A. ninae, and Halophiloscia trichoniscoides comb. nov.) and three new species (Tylos negroi López-Orozco, Carpio-Díaz \& Campos-Filho sp. nov., Stenoniscus nestori López-Orozco, Taiti \& Campos-Filho sp. nov., and Armadilloniscus luisi CarpioDíaz, Taiti \& Campos-Filho sp. nov.). Only two species were observed in the tropical dry forest, Trichorhina bermudezae and T. heterophthalma, which had previously been reported in this habitat on the mainland, in the northern Bolívar department (Carpio-Díaz et al. 2018). Eight of the 17 species have only been reported in the Caribbean region and nine are reported for the first time in Colombia (Table 1).

Molecular phylogenetic analyses supported the identification of three species of Tylos in Isla Grande and the recognition of one of them as a new species. The species identified as T. marcuzzii clustered with specimens identified as this species from two Cuban localities. The genetic distance between the specimens from Isla Grande and those from Cuba ranged between 2.0 and 2.7\% for $12 \mathrm{~S}$ rDNA, whereas the divergence between the two Cuban specimens was $2.0 \%$. These probably correspond to species-level divergences (Hurtado et al. 2013). The Isla Grande specimens from Laguna Caracolí and Caño Ratón recognized as $T$. niveus were recovered as closely related with the specimen from the Florida Keys, type locality of the species. The genetic distance between specimens of $T$. niveus from the Isla Grande and the Florida Keys was $2.7 \%$ for $16 \mathrm{~S}$ rDNA. The lineage formed by the T. niveus from Isla Grande and Florida is part of a cluster in which a basal polytomy of five lineages, including this lineage, was observed. Another basal lineage corresponds to the new species $T$. negroi sp. nov., indicating the high degree of genetic differentiation of this isopod within this cluster. The other three basal lineages include a clade of specimens from the Northeastern Pacific (referred to as T. punctatus sensu lato in Hurtado et al. 2014), which appears to be a clade conformed by multiple species (Hurtado et al. 2013), a lineage previously identified as T. niveus from Aguada, Puerto Rico (Hurtado et al. 2014), and a lineage previously identified as Tylos sp. from Yaguanabo, Cuba (Hurtado et al. 2014). Genetic distances among the basal lineages range from 9.7 to $15.5 \%$ for $12 \mathrm{~S}$ rDNA and 11.1 to $13.6 \%$ for $16 \mathrm{~S}$ rDNA, which appear to correspond to species-level divergences in Tylos. Hurtado et al. (2013) reported smaller genetic divergences among multiple lineages that show morphological differences and appear to represent different species within the Northeastern Pacific clade. Although the lineage from Puerto Rico was previously identified as T. niveus, it probably corresponds to a different species, because it is highly divergent from the specimen from the Florida Keys, type locality of T. niveus. Similarly, Tylos sp. from Yaguanabo, Cuba, also appears to correspond to a different species. It is important to obtain more specimens of Tylos from the Caribbean to better understand the diversity patterns of this group in the region, and to use more markers, employing genomic methods, which could help solve the relationships among the five basal lineages.

We identified the Ligia found in Isla Grande as L. baudiniana. The taxonomy of L. baudiniana, however, needs revision. This species was originally described by Milne-Edwards (1840), from the 
surrounding of the San Juan de Ulúa Fort in the city of Veracruz, Gulf of Mexico, Mexico. However, specimens recently collected by LH from there corresponded to Ligia exotica Roux, 1828 (Santamaria et al. 2014; Hurtado et al. 2018). Santamaria et al. (2014) identified a monophyletic clade of Ligia distributed in the Caribbean Sea, Bahamas, southern Florida, Bermuda, and the Pacific coast of Central America and Colombia. Males of this clade have in their pleopod 2 endopod a large lateral process that bifurcates close to the apex (Leistikow 1997: fig. 6 and Santamaria et al. 2014: fig. 4). Schultz (1972) and Schultz \& Johnson (1984) assigned specimens from Florida and Bermuda with this characteristic to L. baudiniana. Santamaria et al. (2014) found that this clade is comprised of seven highly divergent lineages, which, based on their divergences, might warrant separate species status. One of the clades (Clade E in Santamaria et al. 2014), was observed on the Magdalena coast of Colombia, about $280 \mathrm{~km}$ northeast of Isla Grande. Unfortunately, we could not obtain molecular data for the specimens of Isla Grande, but molecular analyses will reveal whether they also belong to Clade E or to another lineage.

This study clearly shows the high potential for discovering unknown biodiversity of coastal oniscideans, a poorly studied group, in the Caribbean region. An examination of the oniscidean diversity on a tiny island of the Colombian Caribbean resulted in the description of three new species of coastal oniscideans. This and previous phylogeographic studies of isopods of Tylos and Ligia are revealing high levels of cryptic biodiversity in the Caribbean region, suggesting a high potential for finding much more diversity if sampling is expanded (Hurtado et al. 2014; Santamaria et al. 2014). As coastal habitats are threatened by multiple factors in the region, and unique evolutionary lineages of coastal oniscideans are at imminent risk, it is important to continue taxonomic and systematic studies of this group to identify diversity patterns and protect members of this highly diverse group. Coastal isopods can be informative on the processes that have contributed to the extraordinary diversity of the Caribbean region. For example, the phylogeographic study of Ligia allowed for testing different hypotheses to explain diversification patterns within this group, which included competing geological hypotheses and oceanic circulation patterns, and also provided evidence of multiple Atlantic-Pacific divergences, which appear to reflect separate vicariant events (Santamaria et al. 2014). Interestingly, studies of other coastal isopods have also shown multiple transisthmian divergences, a highly debated topic in evolutionary studies of the region (Hurtado et al. 2016, 2017). Coastal oniscideans also have the potential of being used as biomonitors of contamination (García-Hernández et al. 2015), and it is important to understand their diversity well in order to correctly interpret coastal ecological studies (Mattos et al. 2018). Our work on Tylos highlights the importance of combining taxonomic and molecular analyses to support taxonomic decisions and uncover cryptic diversity. The already published dataset of mitochondrial sequences for most nominal species of this genus (Hurtado et al. 2014) made the molecular phylogenetics analyses for specimens of Tylos possible. Given the multiple threats to coastal habitats in the Caribbean region, it is of upmost importance to generate similar molecular information for other oniscidean species to better analyze their diversification patterns in the region.

\section{Acknowledgements}

COLCIENCIAS, University of Cartagena and the Consejo Comunitario of the Islas del Rosario provided financial support to the project "Diseño e implementación del sendero eco turístico estratégico para el aprovechamiento sostenible de los ecosistemas del manglar y bosque seco tropical en Isla Grande (Cartagena-Bolivar)", Contract No. FP44842-484-2016. Vicerrectoría de Investigaciones and Grupo de Investigación Hidrobiología of the University of Cartagena provided a scholarship to CML-O (Resolución $\mathrm{N}^{\circ}$ 01478-2019, Programa de Movilidad Internacional de Estudiantes - International Program of Student Mobility) and financial support (Plan de Fortalecimiento 2019, Acta de Compromiso $N^{\circ}$ 024-2019). The University of Florence (Italy) is thanked for hosting CML-O. The Department of Wildlife and Fisheries Sciences at Texas A\&M University provided funds for field and molecular work to LAH and AO. Cristián Herrera, Juan Felipe Romero, and the "Observatorio para el Desarrollo Sostenible de las Islas 
del Rosario y San Bernardo" provided assistance in the production of the map of Isla Grande. Hernando Gómez Molina (Sr Negro) and Ms Miriam (Sector La Punta) provided assistance during fieldwork in Isla Grande. Jordan Hernández, Keiner Meza Tilvez, Alison Figueroa, Brandon Valencia and Luis Vides helped during collections. Research Project titled "Biodiversity of terrestrial isopods (Crustacea, Isopoda, Oniscidea) from Cyprus in the light of integrative taxonomy", funded by the "ONISILOS Research Program - 2018", University of Cyprus, for the postdoctoral fellowship granted to ISC-F; CAPES (Coordenação de Aperfeiçoamento de Pessoal de Nível Superior), Finance Code 001, and a Programa Nacional de Pós-Doutorado scholarship provided to ISC-F during his postdoctoral at UFCG (CAPES/PNPD/UFCG/CTRN/PPGRN/201713705-5). This work is a partial result of the Master's thesis of CML-O.

\section{References}

Altekar G., Dwarkadas S., Huelsenbeck J.P. \& Ronquist F. 2004. Parallel Metropolis coupled Markov chain Monte Carlo for Bayesian phylogenetic inference. Bioinformatics 20: 407-415. https://doi.org/10.1093/bioinformatics/btg427

Araujo P.B. \& Taiti S. 2007. Terrestrial isopods (Crustacea, Oniscidea) from Rocas Atoll, northeastern Brazil. Arquivos do Museu Nacional 65: 347-355.

Arcangeli A. 1957. Il genere Armadilloniscus Ulj. e gli Scyphacidae (crostacei isopodi terrestri). Atti della reale Accademia delle Scienze di Torino 91: 399-428.

Ashmole P. \& Ashmole M. 2000. St Helena and Ascension Island: a Natural History. Anthony Nelson, Oswestry, England.

Boone L. 1934. New and rare Cuban and Haitian terrestrial Isopoda. Bulletin of the American Museum of Natural History 66: 567-598.

Brandt J.F. 1833. Conspectus Monographiae Crustaceorum Oniscodorum Latreillii. Byulleten Moskovskogo Obshchestva Ispŷtateleı̆ Prirodŷ 6: 171-193.

Brummitt N. \& Lughadha E.N. 2003. Biodiversity: where's hot and where's not. Conservation Biology 17: 1442-1448. https://doi.org/10.1046/j.1523-1739.2003.02344.x

Budde-Lund G. 1885. Crustacea Isopoda terrestria per familias et genera et species descripta. Nielsen \& Lydiche, Copenhagen, Denmark. https://doi.org/10.5962/bhl.title.109769

Budde-Lund G. 1904. A Revision of Crustacea Isopoda Terrestria, with Additions and Illustrations. Pt 1 Eubelum, Pt 2 Spherilloninae, Pt 3 Armadillo. H. Hagerup, Copenhagen, Denmark.

Campos-Filho I.S., Araujo P.B., Bichuette M.E., Trajano E. \& Taiti S. 2014. Terrestrial isopods (Crustacea: Isopoda: Oniscidea) from Brazilian caves. Zoological Journal of the Linnean Society 172 (2): 360-425. https://doi.org/10.1111/zoj.12172

Campos-Filho I.S., Montesanto G., Araujo P.B. \& Taiti S. 2017. New species and new records of terrestrial isopods (Crustacea, Isopoda, Oniscidea) from Brazil. Iheringia, Série Zoologia 107: e2017034. https://doi.org/10.1590/1678-4766e2017034

Campos-Filho I.S., Cardoso G.M. \& Aguiar J.O. 2018. Catalogue of terrestrial isopods (Crustacea, Isopoda, Oniscidea) from Brazil: an update with some considerations. Nauplius 26: e2018038. https://doi.org/10.1590/2358-2936e2018038

Campos-Filho I.S., Fernandes C.S., Cardoso G.M., Bichuette M.E., Aguiar J.O. \& Taiti S. 2020. New species and new records of terrestrial isopods (Crustacea, Isopoda, Oniscidea) of the families Philosciidae and Scleropactidae from Brazilian caves. European Journal of Taxonomy 606: 1-38. https://doi.org/10.5852/ejt.2020.606 
Carpio-Díaz Y.M., López-Orozco C.M., Herrera-Medina Y., Navas G.R. \& Bermúdez A. 2016. Primer registro de Tylos niveus y nuevo reporte de Porcellionides pruinosus (Oniscidea: Tylidae y Porcellionidae) para Colombia. Revista de la Academia colombiana de Ciencias exactas fisicas y naturales 40 (156): 433-437. https://doi.org/10.18257/raccefyn.343

Carpio-Díaz Y.M., López-Orozco C.M., Campos-Filho I.S. \& Navas G.R. 2018. Terrestrial isopods (Isopoda: Oniscidea) of the Botanical Garden of Cartagena "Guillermo Piñeres", Colombia, with the description of three new species. Arthropoda Selecta 27 (4): 301-318.

https://doi.org/10.15298/arthsel.27.4.05

Coleman C.O. 2015. Taxonomy in times of the taxonomic impediment - Examples from the community of experts on amphipod crustaceans. Journal of Crustacean Biology 25 (6): 729-740.

https://doi.org/10.1163/1937240X-00002381

Dimitriou A.C., Taiti S. \& Sfenthourakis S. 2019. Genetic evidence against monophyly of Oniscidea implies a need to revise scenarios for the origin of terrestrial isopods. Scientific Reports 9: e18508 (1-10). https://doi.org/10.1038/s41598-019-55071-4

Ebach M.C., Valdecasas A.G. \& Wheeler Q.D. 2011. Impediments to taxonomy and users of taxonomy: accessibility and impact evaluation. Cladistics 27: 550-557.

https://doi.org/10.1111/j.1096-0031.2011.00348.x

Eberl R., Mateos M., Grosberg R.K., Santamaria C.A. \& Hurtado L.A. 2013. Phylogeography of the supralittoral isopod Ligia occidentalis around the Point Conception marine biogeographic boundary. Journal of Biogeography 40: 2361-2372. https://doi.org/10.1111/jbi.12168

Espinosa-Pérez M.C. \& Hendrickx M.E. 2001. Checklist of isopods (Crustacea: Peracarida: Isopoda) from the Eastern Tropical Pacific. Belgian Journal of Zoology 131 (1): 43-55.

Ferrara F. \& Taiti S. 1982. Isopodi terrestri delle Isole Andamane. Bollettino del Museo civico di Storia naturale di Verona 8: 459-492.

Ferrara F. \& Taiti S. 1986. The terrestral isopods (Oniscidea) of the Arabian Peninsula. Fauna of Saudi Arabia 7: 93-121.

García-Hernández J., Hurtado L.A., Leyva-García G., Güido-Moreno A., Aguilera-Márquez D., Mazzei V. \& Ferrante M. 2015. Isopods of the genus Ligia as potential biomonitors of trace metals from the gulf of California and pacific coast of the Baja California peninsula. Ecotoxicology and Environmental Safety 112: 177-185. https://doi.org/10.1016/j.ecoenv.2014.11.002

Garthwaite R., Lawson R. \& Taiti S. 1992. Morphological and genetical relationships among four species of Armadilloniscus Uljanin, 1875 (Isopoda: Oniscidea: Scyphacidae). Journal of Natural History 26: 327-338. https://doi.org/10.1080/00222939200770171

Giordani Soika A. 1954. Ecologia, sistematica, biogeografia ed evoluzione del Tylos latreillei. Bollettino del Museo civico di Storia naturale di Venezia 7: 63-83.

Guarderas A.P., Hacker S.D. \& Lubchenco J. 2008. Current status of marine protected areas in Latin America and the Caribbean. Conservation Biology 22 (6): 1630-1640.

https://doi.org/10.1111/j.1523-1739.2008.01023.x

Hurtado L.A., Mateos M. \& Santamaria C.A. 2010. Phylogeography of supralittoral rocky intertidal Ligia isopods in the Pacific region from Central California to Central Mexico. PLoS ONE 5 (7): e11633. https://doi.org/10.1371/journal.pone.0011633

Hurtado L.A., Lee E.J. \& Mateos M. 2013. Contrasting phylogeography of sandy vs. rocky supralittoral isopods in the megadiverse and geologically dynamic Gulf of California and adjacent areas. PLoS ONE 8 (7): e67827. https://doi.org/10.1371/journal.pone.0067827 
Hurtado L.A., Lee E.J., Mateos M. \& Taiti S. 2014. Global diversification at the harsh sea-land interface: mitochondrial phylogeny of the supralittoral isopod genus Tylos (Tylidae, Oniscidea). PloS ONE 9 (4): e94081. https://doi.org/10.1371/journal.pone.0094081

Hurtado L.A., Mateos M., Mattos G., Liu S., Haye P.A. \& Paiva P.C. 2016. Multiple transisthmian divergences, extensive cryptic diversity, occasional long-distance dispersal, and biogeographic patterns in a marine coastal isopod with an amphi-American distribution. Ecology and Evolution 6: 7794-7808. https://doi.org/10.1002/ece3.2397

Hurtado L.A., Mateos M. \& Liu S. 2017. Phylogeographic patterns of a lower intertidal isopod in the Gulf of California and the Caribbean and comparison with other intertidal isopods. Ecology and Evolution 7: 346-357. https://doi.org/10.1002/ece3.2599

Hurtado L.A., Mateos M., Wang C., Santamaria C.A., Jung J., Khalaji-Pirbalouty V. \& Kim W. 2018. Out of Asia: mitochondrial evolutionary history of the globally introduced supralittoral isopod Ligia exotica. PeerJ 6: e4337. https://doi.org/10.7717/peerj.4337

Jackson H.G. 1922. A revision of the isopod genus Ligia (Fabricius). Proceedings of the Zoological Society of London 92 (3): 683-703. https://doi.org/10.1111/j.1096-3642.1922.tb02164.x

Javidkar M., Cooper S.J.B., King R.A., Humphreys W.F. \& Austin A. 2015. Molecular phylogenetic analyses reveal a new southern hemisphere oniscidean family (Crustacea: Isopoda) with a unique water transport system. Invertebrate Systematics 29: 554-577. https://doi.org/10.1071/IS15010

Javidkar M., King R.A., Cooper S.J.B., Humphreys W.F. \& Austin A. 2017. Taxonomy of Paraplatyarthrus Javidkar and King (Isopoda: Oniscidea: Paraplatyarthridae) with description of five new species from Western Australia, and comments on Australian Trichorhina Budde-Lunde [sic], 1908 (Platyarthridae). Zootaxa 4243 (3): 401-431. https://doi.org/10.11646/zootaxa.4243.3.1

Kalyaanamoorthy S., Minh B.Q., Wong T.K.F., von Haeseler A. \& Jermiin L.S. 2017. ModelFinder: Fast model selection for accurate phylogenetic estimates. Nature Methods 14: 587-589.

https://doi.org/10.1038/nmeth.4285

Kensley B. \& Schotte M. 1989. Guide to the Marine Isopod Crustaceans of the Caribbean. Smithsonian Institution Press, Washington.

Available from https://www.biodiversitylibrary.org/page/10950583 [accessed 6 Jan. 2022].

Kerswell A.P. 2006. Global biodiversity patterns of benthic marine algae. Ecology 87: 2479-2488. https://doi.org/bmxb43

Kwon D.H. \& Wang C.H. 1996. Two new species of Armadilloniscus Uljanin, 1875 (Isopoda, Oniscidea, Scyphacidae) from Taiwan. The Korean Journal of Systematic Zoology 12 (1): 83-89.

Lam-Tung N., Schmidt H.A., Haeseler A. \& Minh B.Q. 2015. IQ-TREE: A fast and effective stochastic algorithm for estimating maximum likelihood phylogenies. Molecular Biology and Evolution 32: 268274. https://doi.org/10.1093/molbev/msu300

Lazarus-Agudelo J.F. \& Cantera-Kintz J.R. 2007. Crustáceos (Crustacea: Sessilia, Stomatopoda, Isopoda, Amphipoda, Decapoda) de Bahía Málaga, Valle del Cauca (Pacífico Colombiano). Biota Colombiana 8 (2): 221-239.

Leistikow A. 1997. Terrestrial isopods from Costa Rica and a redescription of Ischioscia variegata (Dollfus, 1893) (Crustacea: Isopoda: Oniscidea). Canadian Journal of Zoology 75 (9): 1415-1464. https://doi.org/10.1139/z97-768

Leistikow A. 2000. Terrestrial Isopoda from Guatemala and Mexico (Crustacea: Oniscidae: Crinocheta). Revue suisse de Zoologie 107: 283-323. https://doi.org/10.5962/bhl.part.80131 
Leistikow A. \& Wägele J.W. 1999. Checklist of terrestrial isopods of the New World (Crustacea, Isopoda, Oniscidea). Revista brasileira de Zoologia 16: 1-72.

https://doi.org/10.1590/S0101-81751999000100001

Lemos de Castro A. 1964. Trichorhina heterophthalma nueva especie de isopodo terrestre cavernicola de Cuba. Poeyana 2A: 1-7.

Lins L.S.F., Ho S.Y.W. \& Lo N. 2017. An evolutionary timescale for terrestrial isopods and a lack of molecular support for the monophyly of Oniscidea (Crustacea: Isopoda). Organisms Diversity \& Evolution 17: 813-820. https://doi.org/10.1007/s13127-017-0346-2

Lisboa J.T., Campos-Filho I.S., Couto E.C.G. \& Araujo P.B. 2017. Distribution of terrestrial isopods of the genus Littorophiloscia (Isopoda, Halophilosciidae) along the Brazilian coast. North-Western Journal of Zoology 13: e167301.

López-Orozco C.M., Bermúdez A. \& Navas G.R. 2014. Primer registro de Ligia baudiniana (Crustacea: Isopoda: Oniscidea) para el Caribe Colombiano. Boletín de Investigaciones marinas y costeras 43 (1): 195-200. https://doi.org/10.25268/bimc.invemar.2014.43.1.41

López-Orozco C.M., Carpio-Díaz Y.M., Navas G.R. \& Campos-Filho I.S. 2017. A new species and first record of Pulmoniscus Leistikow, 2001 (Isopoda, Oniscidea, Philosciidae) from Colombia. Nauplius 25: e2017014. https://doi.org/10.1590/2358-2936e2017014

Lorde T., Gomes C., Alleyne D. \& Phillips W. 2013. An Assessment of the Economic and Social Impacts of Climate Change on the Coastal and Marine Sector in the Caribbean. Economic Commission for Latin America and the Caribbean (ECLAC), United Nations.

Available from https://repositorio.cepal.org/handle/11362/38519 [accessed 6 Jan. 2022].

Mattos G., Paiva P.C., Mateos M., Haye P.A. \& Hurtado L.A. 2018. The cost of ignoring cryptic diversity in macroecological studies: Comment on Martinez et al. (2017). Marine Ecology Progress Series 601: 269-271. https://doi.org/10.3354/meps12701

Milne-Edwards M. 1840. Ordre des isopodes. In: Histoire Naturelle des Crustacés, comprenant l'Anatomie, la Physiologie et la Classficiation de ces Animaux. Tome Troisième. 115-283. Librairie Encyclopédique de Roret, Paris.

Miloslavich P., Diaz J.M., Klein E., Alvarado J.J., Diaz C., Gobin J., Escobar-Briones E., Cruz-Motta J.J., Weil E., Cortés J., Bastidas A.C., Robertson R., Zapata F., Martín A., Castillo J., Kazandjian A. \& Ortiz M. 2010. Marine biodiversity in the Caribbean: regional estimates and distribution patterns. PLoS ONE 5: e11916. https://doi.org/10.1371/journal.pone.0011916

Montesanto G. 2015. A fast GNU method to draw accurate scientific illustrations for taxonomy. ZooKeys 515: 191-206. https://doi.org/10.3897/zookeys.515.9459

Montesanto G. 2016. Drawing setae: a GNU way for digital scientific illustrations. Nauplius 24: e2016017. https://doi.org/10.1590/2358-2936e2016017

Myers N., Mittermeier R.A., Mittermeier C.G., Da Fonseca G.A.B. \& Kent J. 2000. Biodiversity hotspots for conservation priorities. Nature 403: 853-858. https://doi.org/10.1038/35002501

Naser M.D., Khalaf T.A. \& Yasser A.G. 2015. First record of the terrestrial isopod Littorophiloscia culebrae (H.F. Moore, 1901) (Isopoda, Oniscidea) from Khor Al-Zubair, Iraq and the Persian Gulf. Crustaceana 88 (5): 611-615. https://doi.org/10.1163/15685403-00003432

Niño L.M., González G., Rodríguez M., Landazábal E., Herrera L.F. \& Rodríguez F. 2010. Sistema de Gestion Ambiental - SIGAM, Archipielago Islas del Rosario, San Bernardo e Islafuerte. Corporación Autónoma Regional del Canal del Dique y Universidad Jorge Tadeo Lozano Seccional Caribe, Cartagena, Colombia. 
Núñez S.G., López N.H., García C.B. \& Navas G.R. 1999. Bimonthly characterization and behavior of the sessile community associated with the rocky littoral of Bocachica, Tierra Bomba Island, Colombian Caribbean. Ciencias Marinas 25 (4): 629-646. https://doi.org/10.7773/cm.v25i4.722

Paoletti M.G. \& Stinner B.R. 1989. Two new terrestrial Isopoda (Oniscidea) from coralline cays of Venezuela's Caribbean coast. Proceedings of the Entomological Society of Washington 91 (1): 71-80. Available from https://biostor.org/reference/56403 [accessed 6 Jan. 2022].

Pearse A.S. 1915. An account of the Crustacea collected by the Walker Expedition to Santa Marta, Colombia. Proceedings of the United States National Museum 49: 531-556.

https://doi.org/10.5479/si.00963801.49-2123.531

Pineda I.J., Martínez L.A., Bedoya D.M., Caparroso P. \& Rojas J.A. 2006. Plan de manejo del Parque Nacional Natural Corales del Rosario y San Bernardo. UAESPNN, Territorial Costa Caribe, Cartagena, Colombia. Available from

http://www.parquesnacionales.gov.co/portal/wp-content/uploads/2013/12/Corales.pdf [accessed 6 Jan. 2022].

Reinoso-Flórez G., Villa-Navarro F.A. \& Losada-Prado S. 2016. Artropofauna epigea del páramo Estambul (Tolima), Colombia. Biota Colombiana 17 (2): 39-51.

Available from http://hdl.handle.net/20.500.11761/9381 [accessed 6 Jan. 2022].

Richardson H. 1912. Terrestrial isopods of Colombia. Mémoires de la Société des Sciences naturelles Neuchâtel 5: 29-32.

Ricklefs R. \& Bermingham E. 2008. The West Indies as a laboratory of biogeography and evolution. Philosophical Transactions of the Royal Society B: Biological Sciences 363: 2393-2413.

https://doi.org/10.1098/rstb.2007.2068

Ríos R. \& Ramos G.E. 1990. Los isopodos (Crustacea: Isopoda) de Bahía Málaga, Colombia. Revista de Ciencias, Universidad del Valle 2: 83-96.

Roberts C.M., Mcclean C.J., Veron J.E.N., Hawkins J.P., Allen G.R., Mcallister D.E., Mittermeier C.G., Schueler F.W., Spalding M., Wells F., Vynne C. \& Werner T.B. 2002. Marine biodiversity hotspots and conservation priorities for tropical reefs. Science 295: 1280-1284.

https://doi.org/10.1126/science.1067728

Rojas X., Leonardo O., López A., Zamora A.P., Rocha V. \& Andrade D. (eds). 2012. Plan de Manejo del Área Marina Protegida de los Archipiélagos de Rosario y San Bernardo AMPARSB (2013-2023). Instituto de Investigaciones Marinas y Costeras - Ministerio de Ambiente y Desarrollo Sostenible, Santa Marta, Colombia.

Romero J.F. \& Niño L.M. 2014. Atlas ambiental de los Archipiélagos de Nuestra Señora del Rosario y de San Bernardo. Incoder - Universidad de Bogotá Jorge Tadeo Lozano, Cartagena, Colombia.

Ronquist F., Teslenko M., van der Mark P., Ayres D.L., Darling A., Höhna S., Larget B., Liu L., Suchard M.A. \& Huelsenbeck J.P. 2012. MrBayes 3.2: efficient Bayesian phylogenetic inference and model choice across a large model space. Systematic Biology 61: 539-542.

https://doi.org/10.1093/sysbio/sys029

Rosen D.E. 1975. A vicariance model of Caribbean biogeography. Systematic Biology 24: 431-464. https://doi.org/10.1093/sysbio/24.4.431

Santamaria C.A., Mateos M., Taiti S., DeWitt T.J. \& Hurtado L.A. 2013. A complex evolutionary history in a remote archipelago: phylogeography and morphometrics of the Hawaiian endemic Ligia isopods. PLoS ONE 8 (12): e85199. https://doi.org/10.1371/journal.pone.0085199 
Santamaria C.A., Mateos M.C. \& Hurtado L.A. 2014. Diversification at the narrow sea-land interface in the Caribbean: phylogeography of endemic supralittoral Ligia isopods. Frontiers in Ecology and Evolution 2: e42. https://doi.org/10.3389/fevo.2014.00042

Schmalfuss H. 1984. Eco-morphological strategies in terrestrial isopods. Proceedings of the Zoological Society of London 53: 49-63.

Schmalfuss H. 2003. World catalog of terrestrial isopods (Isopoda: Oniscidea). Stuttgarter Beiträge zur Naturkunde A 654: 1-341.

Schmalfuss H. \& Ferrara F. 1978. Terrestrial isopods from West Africa, Part 2: families Tylidae, Ligiidae, Trichoniscidae, Styloniscidae, Rhyscotidae, Halophilosciidae, Philosciidae, Platyarthridae, Rhyscotidae, Trachelipidae, Porcellionidae, Armadillidiidae. Monitore zoologico italiano, nuova serie, Supplemento 11: 15-9. https://doi.org/10.1080/03749444.1978.10736575

Schmalfuss H. \& Vergara K. 2000. The isopod genus Tylos (Oniscidea: Tylidae) in Chile, with bibliographies of all described species of the genus. Stuttgarter Beiträge zur Naturkunde A 612: 1-42.

Schmidt C. 2001. Lista preliminar de los isópodos terrestres (Crustacea, Isopoda, Oniscidea) de Venezuela. Boletín de la Sociedad venezolana de Espeleología 35: 1-12.

Schmidt C. 2002. Contribution to the phylogenetic system of the Crinocheta (Crustacea, Isopoda). Part 1 (Olibrinidae to Scyphacidae s. str.). Mitteilungen aus dem Museum für Naturkunde in Berlin, Zoologische Reihe 78: 275-352. https://doi.org/10.1002/mmnz.20020780207

Schmidt C. 2003. Contribution to the phylogenetic system of the Crinocheta (Crustacea, Isopoda). Part 2 (Oniscoidea to Armadillidiidae). Mitteilungen aus dem Zoologischen Museum in Berlin, Zoologische Reihe 79: 3-179. https://doi.org/10.1002/mmnz.20030790102

Schmidt C. \& Leistikow A. 2004. Catalogue of genera of the terrestrial Isopoda (Crustacea: Isopoda: Oniscidea). Steenstrupia 28 (1): 1-118.

Schotte M. \& Heard R.W. 1991. Studies on the Crustacea of the Turks and Caicos Islands, British West Indies. II. Armadilloniscus steptus, n. sp. (Isopoda: Oniscidea: Scyphacidae) from Pine Cay. Gulf Research Reports 8 (3): 247-250. https://doi.org/10.18785/grr.0803.04

Schultz G.A. 1970. A review of the species of the genus Tylos Latreille from the New World (Isopoda. Oniscidea). Crustaceana 19: 297-30. https://doi.org/10.1163/156854070X00383

Schultz G.A. 1972. Ecology and systematics of terrestrial isopod crustaceans from Bermuda. Crustaceana, Supplement 3: 79-99. Available from https://www.jstor.org/stable/25027410 [accessed 7 Jan. 2022].

Schultz G.A. 1974. Terrestrial isopod crustaceans (Oniscoidea) mainly from the West Indies and adjacent regions: 1. Tylos and Ligia. Studies on the fauna of Curaçao and other Caribbean islands 149: 162-173. Available from http://www.repository.naturalis.nl/document/549820 [accessed 7 Jan. 2022].

Schultz G.A. 1984. Three new and five other species of Oniscoidea from Belize, Central America (Crustacea, Isopoda). Journal of Natural History 18: 3-14. https://doi.org/10.1080/00222938400770021

Schultz G.A. \& Johnson C. 1984. Terrestrial isopod crustaceans from Florida (Oniscoidea). Tylidae, Ligiidae, Halophilosciidae, Philosciidae and Rhyscotidae. Journal of Crustacean Biology 4 (1): 154171. https://doi.org/10.2307/1547904

Sfenthourakis S. \& Taiti S. 2015. Patterns of taxonomic diversity among terrestrial isopods. ZooKeys 515: 13-25. https://doi.org/10.3897/zookeys.515.9332

Sfenthourakis S., Myers A.A., Taiti S. \& Lowry J.K. 2020. Chapter 14. Terrestrial environments. In: Thiel M. \& Poore G. (eds) The Natural History of the Crustacea: Evolution and Biogeography of the Crustacea, Vol. 8: 359-388. Oxford University Press, Carey, NC, USA. 
Silva J. \& Alves E. 2000. Tylos niveus Budde-Lund, 1885 (Crustacea: Isopoda: Oniscidea: Tylidae): redescrição e nova ocorrência para a praia de Taquaras, Santa Catarina, Brasil. Acta Biológica Paranaense 29 (1-4): 265-285. https://doi.org/10.5380/abpr.v29i0.595

Swofford D.L. 2002. PAUP*. Phylogenetic Analysis Using Parsimony (*and Other Methods). Version 4. Sinauer Associates, Sunderland, MA, USA.

Taiti S. 2014. The terrestrial Isopoda (Crustacea, Oniscidea) of the Maldives. Tropical Zoology 27 (1): 9-33. https://doi.org/10.1080/03946975.2014.894397

Taiti S. \& Argano R. 2009. New species of terrestrial isopods from Sardinia (Isopoda: Oniscidea). Zootaxa 2318 (1): 38-55. https://doi.org/10.11646/zootaxa.2318.1.5

Taiti S. \& Argano R. 2011. Oniscidea di Sardegna (Crustacea, Isopoda). Conservazione Habitat Invertebrati 5: 163-222.

Taiti S. \& Checcucci I. 2009. New species and records of terrestrial Isopoda (Crustacea, Oniscidea) from Socotra Island, Yemen. ZooKeys 31: 73-103. https://doi.org/10.3897/zookeys.31.140

Taiti S. \& Ferrara F. 1982. Metastenoniscus osellai nuovo genere e nuova specie di isopodo terrestre (Stenoniscidae) dell'Isola di Bali. Bollettino del Museo civico di Storia naturale di Verona 8 (1981): 443-452.

Taiti S. \& Ferrara F. 1986. Taxonomic revision of the genus Littorophiloscia Hatch, 1947 (Crustacea, Isopoda, Oniscidea) with description of six new species. Journal of Natural History 20: 1347-1380. https://doi.org/10.1080/00222938600770911

Taiti S. \& Ferrara F. 1989. New species and records of Armadilloniscus Uljanin 1875 (Crustacea Isopoda Oniscidea) from the coasts of the Indian and Pacific oceans. Tropical Zoology 2: 59-88. https://doi.org/10.1080/03946975.1989.10539427

Taiti S. \& Ferrara F. 2004. The terrestrial Isopoda (Crustacea: Oniscidea) of the Socotra Archipelago. Fauna of Arabia 20: 211-326.

Taiti S. \& Lopez H. 2008. New records and species of Halophilosciidae (Crustacea, Isopoda, Oniscidea) from the Canary Islands (Spain). In: Zimmer M., Charfi-Cheikhrouha F. \& Taiti S. (eds) Proceedings of the International Symposium of Terrestrial Isopod Biology ISTIB-07: 43-58. Shaker-Verlag, Aachen, Germany.

Taiti S. \& Wynne J. 2015. The terrestrial Isopoda (Crustacea, Oniscidea) of Rapa Nui (Easter Island), with descriptions of two new species. ZooKeys 515: 27-49. https://doi.org/10.3897/zookeys.515.9477

Taiti S., Montesanto G. \& Vargas J. 2018. Terrestrial Isopoda (Crustacea, Oniscidea) from the coasts of Costa Rica, with descriptions of three new species. Revista de Biologia tropical 66 (1): S187-S210. https://doi.org/10.15517/RBT.V66I1.33296

Vandel A. 1944. Isopodes terrestres récoltés par M. Remy au cours de son voyage en Corse. II. La famille de Stenoniscidae. Archives de Zoologie expérimentale et générale 84: 23-47.

Vandel A. 1962. Isopodes terrestres (Deuxième Partie). Faune de France 66: 417-931.

Vandel A. 1973. Les isopodes terrestres et cavernicoles de l'île de Cuba. In: Orghidan T., Núñez A., Botosaneanu L., Decou V., Negrea Ş. \& Viña N. (eds) Résultats des Expéditions biospéologiques cubanoroumaines à Cuba, vol. 1: 153-188. Editura Academiei Republicii Socialiste România, Bucharest.

Van Name W. 1936. The American land and freshwater isopod Crustacea. Bulletin of the American Museum of Natural History 71: 1-535. 
Verhoeff K.W. 1942. Landisopoden der Insel Ischia, systematisch, morphologisch, phänologisch, ökologisch, geographisch beurteilt. Zeitschrift für Morphologie und Ökologie der Tiere 38: 435-482.

Warburg M.R. 1993. Evolutionary Biology of Land Isopods. Springer, Heidelberg.

WoRMS - World Register of Marine Species. 2020a. Oniscidea.

Available from http://www.marinespecies.org/aphia.php?p=taxdetails\&id=146505 [accessed 6 Jan. 2022].

WoRMS - World Register of Marine Species. 2020b. Detonidae.

Available from http://www.marinespecies.org/aphia.php?p=taxdetails\&id=248288 [accessed 6 Jan. 2022].

WoRMS - World Register of Marine Species. 2020c. Halophilosciidae.

Available from http://www.marinespecies.org/aphia.php?p=taxdetails\&id=146963 [accessed 6 Jan. 2022].

Manuscript received: 21 September 2021

Manuscript accepted: 23 November 2021

Published on: 9 February 2022

Topic editor: Tony Robillard

Desk editor: Kristiaan Hoedemakers

Printed versions of all papers are also deposited in the libraries of the institutes that are members of the EJT consortium: Muséum national d'histoire naturelle, Paris, France; Meise Botanic Garden, Belgium; Royal Museum for Central Africa, Tervuren, Belgium; Royal Belgian Institute of Natural Sciences, Brussels, Belgium; Natural History Museum of Denmark, Copenhagen, Denmark; Naturalis Biodiversity Center, Leiden, the Netherlands; Museo Nacional de Ciencias Naturales-CSIC, Madrid, Spain; Real Jardín Botánico de Madrid CSIC, Spain; Zoological Research Museum Alexander Koenig, Bonn, Germany; National Museum, Prague, Czech Republic.

Suppl. file 1. Dataset S1. Alignment of $12 \mathrm{~S}$ rDNA dataset with all positions. It contains 53 taxa and 539 characters. https://doi.org/10.5852/ejt.2022.793.1643.5897

Suppl. file 2. Dataset S2. Alignment of $16 \mathrm{~S}$ rDNA dataset with all positions. It contains 59 taxa and 502 characters. https://doi.org/10.5852/ejt.2022.793.1643.5899

Suppl. file 3. Dataset S3. This file contains the concatenated 12S and 16S rDNA genes after removal of positions deemed of ambiguous homology. It contains 43 taxa and 740 characters.

https://doi.org/10.5852/ejt.2022.793.1643.5901 